\title{
A Magyar Királyi Csendőrség részvétele a szovjet ejtőernyős partizánok elleni harcban (1944 szeptember - 1944 november).
}

(The Participation of the Hungarian Royal Gendarmerie in the Fight against the Soviet Paratrooper Partisans

[September 1944 - November 1944].)

\begin{abstract}
Absztrakt
A magyar kommunista emigráció a Szovjetunióban nagy reményeket füzött a szovjet ejtőernyős partizánok magyarországi tevékenységéhez. Ezek a kisebb-nagyobb ejtőernyős partizán alakulatok azonban koránt sem voltak képesek beváltani a hozzájuk füzött reményeket még a többségében nemzetiségek által lakott területeken sem. A szovjet ejtőernyős partizán osztagok nem voltak képesek jelentős károkozásra csak azok az alakulatok élték meg a szovjet haderő térségbe történő benyomulását, amelyek mérsékelt aktivitást fejtettek ki és ezért a honi vezetés a felszámolásukra nagyobb eröt nem vont össze. A szovjet ejtőernyős partizán osztagok eredménytelenségéhez nem csupán az járult hozzá, hogy a magyar lakosság nem volt fogékony a szovjet propaganda tevékenysége iránt, hanem az is, hogy a partizán elhárítás rendkívül jól szervezett volt és széleskörü társadalmi, közigazgatási alapokon nyugodott, amely képes volt csírájában elfojtani a szovjet ejtőernyős partizán osztagok müködését.
\end{abstract}

\section{Kulcsszavak}

Magyar Királyi Csendőrség ； szovjet ejtőernyős partizán osztagok ； Partizánmozgalom Ukrán Törzse ; Szovjetunió Vörös Hadserege ； Magyar Királyi Honvédség

Abstract

Hungarian communist emigres in the Soviet Union had high hopes for the actions of Soviet paratrooper partisans in Hungary. These variously-sized paratrooper partisan units, however, were in no way capable of living up to their expectations, not even in the territories in which ethnic minorities were in the majority. The divisions of the Soviet paratrooper partisans were not capable of inflicting significant damage; that is, only those divisions that saw moderate action (those which had not faced a consolidated larger force that would have liquidated them) made it into the territory under Soviet Red Army control. The ineffectiveness of the Soviet paratrooper partisans was only partly due to the insusceptibility of the Hungarian population to Soviet propaganda; anti-partisan activity was also exceptionally well organized and lay on a broad social and administrative foundation capable of nipping in the bud any activity of the divisions of the Soviet paratrooper partisans.

Key words:

Hungarian Royal Gendarmerie ； Soviet paratrooper partisan divisions ； Partisan movement in Ukraine ； Soviet Red Army ; Royal Hungarian Army

Open Researcher and Contributor ID = Nyílt Kutató és Közremüködő Azonosító (ORCID) : https://orcid.org/0000-0002-4463-3251

Institutional attachements = = Szerző intézményi kötődései :

- University of Szeged = Szegedi Egyetem

- Hungarian Military Science Society = Magyar Hadtudományi Társaság

- Hungarian Historical Society = Magyar Történelmi Társulat 
M agyarország belső rendjének, közbiztonságának, a termelés zavartalanságának megőrzésében a II. világháború évei alatt meghatározó szerepet játszott a Magyar Királyi Csendőrség. A közbiztonsági szolgálat ellátása alapvetően a Magyar Királyi Csendőrség I-X. kerületének keretében müködő 25 osztály (79 szárny), és az ezek alárendeltségébe tartozó 1321 örs állományára hárult. 1941-től 4000 fővel bővítették a testületet, amelynek állománya 1944 júliusában valamivel meghaladta a 22000 föt, ezen belül azonban a napi közbiztonsági feladatot ellátó egységek komoly létszámhiánnyal küzdöttek. Racionalizálás keretében, az erők jobb koncentrálása érdekében 1942 és 1944 között 53 örsöt meg kellett szüntetni. A Magyar Királyi Honvédség egyre nagyobb számban igényelt tábori csendőröket, mintegy 1200 fö került ilyen beosztásban a csapatokhoz. a Magyar Királyi Csendőrség szervezetén belül jelentős számú személyi állományt irányítottak a különböző iskolákhoz, illetve karhatalmi alakulatokhoz. Különösen nagy volt az altiszthiány, amin 1944-ben a szakasz-parancsnokságok felszámolásával és az ott felszabaduló altiszteknek az őrsökre, illetve a más csendőr alakulatokhoz való beosztásával kíséreltek meg enyhíteni a létszámhiányt. ${ }^{1}$

Közel 5000 csendör szolgált a különböző karhatalmi és tanalakulatok állományában. Galántán karhatalmi zászlóaljat állítottak fel, hat századdal (három puskás, egy kerékpáros, egy nehézfegyver és egy kisharckocsi század), egy-egy tanzászlóalj állomásozott Nagyváradon (öt század), Ungváron (két század) és Szombathelyen (két század), a lovas tanosztály (három század) pedig Kiskunhalason kapott elhelyezést. Önálló karhatalmi század müködött Újvidéken, a csendőrkerületek alárendeltségébe pedig további 19 tanszázad került beosztásra (I. ker. Pestszenterzsébet, II. ker. Győr, Tata, Szabadbattyán, III. ker. Letenye, Lenti, IV. ker. Szekszárd, Főherceglak, V. ker. Makó, Újvidék, VI. ker. Debrecen, VII. ker. Miskolc, Salgótarján, VIII. ker. Bárca, Aknaszlatina, IX. ker. Mérk, Bánffyhunyad, Zilah, X. ker. Nagydemeter). A tanszázadok adott helyzetben igénybe vehetők voltak egyéb szolgálati feladatok, köztük karhatalmi szerepkör ellátására is. ${ }^{2}$

A háborús helyzet alakulása, Magyarország hadszíntérré válása jelentős mértékben megnövelte a csendőrség feladatait. Az 1944 áprilisától folyó légi háború, az angol-amerikai, majd szeptembertől a szovjet bombázások kapcsán a légvédelmi figyelőszolgálat ellátása, a kárelhárítás, a kitelepítettek és kibombázottak vidéki elhelyezésének biztosítása terén jelentkeztek új teendök. Kiszélesedett a partizánháború. A ledobott több száz ejtőernyős feladatának megfelelően további gerillákat toborzott a szökött hadifoglyok, a helyi, elsősorban ukrán, ruszin és szlovák lakosság köréből. A csendőrségnek így a Felvidéken vagy Kárpátalján esetenként 400-500 fős, vagy még ennél is nagyobb létszámú, jól felfegyverzett, szovjet katonatisztek által vezetett partizán alakulatokkal kellett felvenni a harcot. 1944 augusztus végén Erdélyben megjelentek a szovjet csapatok, majd szeptember közepén Kárpátaljára is betörtek. A Vörös Hadsereggel szemben — mivel nem állt rendelkezésre kellő honvédségi erő — a katonai vezetés csendör alakulatokat is harcba vetett. ${ }^{3}$

1944 szeptember elején az 1. és 4. Ukrán Front csapatai közvetlen támadást indítottak Magyarország északkeleti határai ellen. A Keleti-Kárpátok nevet viselö hadmüvelet végrehajtása során a két szovjet hadmüveleti csoport 250000 fővel, 5140 löveggel és aknavetővel, 322 harckocsival és rohamlöveggel, 1165 repülőgéppel rendelkezett. Velük szemben, a kelet-szlovák területen és Kárpátalján állomásozó 1 német páncélos hadsereg és az 1 magyar hadsereg létszám tekintetében ugyan fölényben volt, közel 300000 katonát állíthatott csatarendbe, tüzérsége azonban csak 3250 lövegböl és aknavetőböl, páncélos állománya 100 harckocsiból és rohamlövegböl, légiereje pedig mindössze 450 repülögépből állt. A szovjet csapatok tehát a haditechnika terén nyomasztó fölényben voltak. ${ }^{4}$

A nagy áttörő erő és a gépesített harceszközök jelentős száma lehetővé tette a Vörös Hadsereg számara, hogy dinamikusan nyomuljon előre, így az ellenfélnek gyakran nem maradt ideje a hátországi tartalékok mozgósítására és felvonultatására. Ezért magyar részről vészhelyzetben a jelenlévő csendőr egységeket is felhasználták a frontharcok során. Románia 1944. VIII. 23-ai átállása, nyomán a szovjet csapatok zavartalanul juthattak be Dél-Erdélybe, és váratlan támadást indíthattak Észak-Erdély ellen is. A magyar hadvezetés, mivel a térségben kellő tartalékokkal nem rendelkezett, itt is a bevetette a csendőröket az ellenség megállítására. Közismert megbízhatóságuk és fegyelmezettségük révén a csendőröket rendszerint a legkritikusabb helyeken alkalmazták. A csupán szerényen felfegyverzett, nehézfegyverekkel egyáltalán nem rendelkező csendőr alakulatok általában bátran és kitartóan harcoltak ugyan, de a nehéztüzérséggel, páncélosokkal és repülögépekkel támogatott szovjet főerőkkel szemben vívott összecsapásokban súlyos személyi veszteségeket szenvedve felmorzsolódtak. A Magyarországon folyó védelmi harcok során a csendőrség halottakban, sebesültekben, eltüntekben mintegy 11000 föt vesztett, teljes állományának az $50 \%$-át. ${ }^{5}$

Az örsök egészen a front közeledése miatti visszavonásukig folyamatos harcot vívtak a térségben müködő partizánokkal. Az egyre nagyobb létszámú és mind jobban felfegyverzett partizán csoportok 
semlegesítésére a hagyományos csendőrkiképzés és felszerelés, a két fös járőr és a két Mannlicher puska már semmiképp sem volt elegendő. Ezért 1943 végétől úgynevezett rohamcsendőr tanfolyamokat szerveztek. Ezen a hallgatók megismerkedtek a géppisztoly, a golyószóró, a géppuska, a kézigránát használatával, katonai gyalogsági harcászati ismereteket szereztek, gyakorolták a nagyobb fegyveres csoportok elleni harcot. 1944 tavaszáig mintegy 3000 fö kapott ilyen kiképzést. A tanfolyam végeztével az örsökhöz visszakerülő csendőrök „házi továbbképzés” keretében osztották meg új ismereteiket az állomány többi tagjával. Ez is hozzájárult ahhoz, hogy 1944 nyarán a csendőrség még hathatósan fel tudott lépni a magyar területre ledobott ejtőernyős partizáncsoportokkal szemben, ezeket néhány kivétellel gyorsan felszámolták, a bevetett harcosok kétharmadát megölték vagy elfogták. ${ }^{6}$

Magyar területen 1943 augusztus és 1944 augusztus között 35 szovjet ejtőernyős partizán osztag került bevetésre. Az akciók során mintegy 350 fegyveres szállt le. A harcok során mintegy 110 ejtőernyős meghalt, 140 pedig fogságba esett. Mellettük őrizetbe vettek több száz olyan polgári személyt, akik támogatták a partizánok tevékenységét, vagy csatlakoztak hozzájuk. A partizánok elleni alapvetően eredményes fellépés, amelyet helyi szinten a csendőrség irányított lehetővé tette a rend, a köz- és vagyonbiztonság fenntartását a háborús körülmények között is. 1944 szeptember és november között a partizántevékenység kiszélesedett. Három hónap alatt 35 ejtőernyős csoportot dobtak le, mintegy 480 fős összlétszámmal. A földet ért egységek nagy figyelmet fordítottak a toborzásra, már, szétvert partizáncsoportok harcosai, szökött szovjet hadifoglyok, katonaszökevények, és a helyi, többnyire nemzetiségi (ukrán, ruszin, szlovák) lakosság vállalkozó tagjai összegyüjtésére, így a rendvédelmi erőknek gyakran 100 fönél népesebb partizáncsoportokkal kellett megküzdeniük. Ilyen körülmények között a ledobott ejtőernyősök 35\%-át sikerült semlegesíteni, 70 fő meghalt, 100 fő fogságba esett. ${ }^{7}$

1944 öszén a partizánok már komoly tüzerővel rendelkeztek, minden ejtőernyős PPS (dobtáras) géppisztollyal volt felszerelve. A szovjet csapatok közeledése tovább bátorította a partizánokat, akik gyakran már katonai őrségeket vagy csendőr őrsöket is megtámadtak. Az általában 8-10 fös, egymástól nagyobb távolságra elhelyezkedő csendőr őrsök, melyek legénysége gyakran csak puskával rendelkezett, 30-50 fö, automata fegyverekkel felszerelt támadóval szemben csak nehezen tudták megvédeni magukat. Ezért volt fontos, a csendőr karhatalmi- és tanszázadok jelentette tartalék, amelyek segítséget tudtak nyújtani az örsöknek, és bevonásukkal nagyobb tisztogató akciókat lehetett indítani, a nagyobb partizáncsoportok felszámolására, hogy távol tudják tartani a fegyvereseket a lakott településektől. A központi csendőr egységek nagyobb számban voltak ellátva sorozatlövő fegyverekkel, szakaszonként általában 3 golyószóróval és 5-10 géppisztollyal rendelkeztek. A karhatalmi- és tanszázadok frontvonalban történő alkalmazása azonban egyetlen ütőképes tartalékuktól fosztotta meg az őrsöket, melyeknek közben egyre szervezettebb és nagyobb tüzerővel rendelkező partizán erőkkel kellett megküzdeniük. ${ }^{8}$

A csendőrség eredményes tevékenységében jelentős szerepe volt annak is, hogy a Szovjetunióbeli emigráns kommunista vezetés várakozásaival szemben, a magyar lakosság döntő része nem támogatta a partizánokat. Előfordult, hogy a magyar származású ejtőernyősök iránt bizonyos együttérzést mutattak, élelmet, civil ruhát adtak nekik (mint a katonaszökevényeknek), de sokszor igyekeztek rábeszélni őket, hogy adják fel maguk. A nemzetiségi lakosság esetében összetettebb volt a kép. Észak-Erdélyben, a többségében ortodox románság a kommunista eszméket terjesztő partizánoktól idegenkedett, nemzeti alapon azonban szemben állt a magyar állam hatóságaival is, így gyakran nem segítette a csendőrség munkáját. Kárpátalján ugyan volt bizonyos bázisa a kommunista törekvéseknek, a helyi ukrán és ruszin lakosok egy része azonban inkább az általuk hirdetett szláv testvériségi gondolat miatt támogatta az ejtőernyősöket. Hasonló volt a helyzet a felvidéki szlovákok esetében is.

A lakosság magatartását sokszor a félelem is befolyásolta. A partizánok gyakran úgy igyekeztek tekintélyt teremteni, hogy támadást intéztek az államot képviselő helyi hatósági személyek ellen, megölték a körjegyzőt, az erdőőrt, rálőttek csendőrökre. A front gyors közeledése miatt számolni kellett azzal is, hogy a partizánok holnap már az új hatalmat képviselik. Ilyen körülmények között a csendőrség nem mindig kapott megbízható információkat a lakosság részéről. ${ }^{9}$

A magyar területeken bevetett partizánokat kezdetben a Partizánmozgalom Ukrán Törzse (PUT) készítette fel a Kijevtől 8 km-re lévő szvjatosinoi kiképzőbázison. A magyar csoportok alkalmazásába a Szovjetunióban élő magyar kommunista vezetés is bekapcsolódott. A felkészítés, a csoportok összeállítása, illetve a bevetés helyszíne kérdésében NóGRÁDI Sándor, a kiképzőközpont magyar instruktora egyeztetett a PUT parancsnokával, de gyakran megjelent a táborban a pártvezetés részéröl ROSENFELD [RÁKOSI] Mátyás és WEINBERGER [VAS] Zoltán is. 1944 őszére, a korábbi tapasztalatok alapján változott az ejtőernyős partizánok feladatköre és bevetésének módja. Az ősz folyamán ledobott csoportok elsődleges célja az volt, hogy a helyi lakosság, szökött hadifoglyok vagy katonaszökevények bevonásával nagyobb partizán alakulatokat szervezzenek, amelyek komoly zavart kelthettek a hadigazdaság, a 
közlekedés és szállítás, illetve a hétköznapi élet terén. Amint a ledobott ejtőernyősök rádión visszajelezték, hogy szerencsésen megérkeztek és sikerült tábort kialakítaniuk, a PUT újabb csoportokat indított útnak hozzájuk, jelentős hadianyag utánpótlás kíséretében. Ezzel igyekeztek növelni a csoportok ütőképességét és erőfölényt biztosítani számukra a helyi rendvédelmi szervekkel szemben. ${ }^{10}$

1944 október elején a felvidéki és kárpátaljai területeken zajló partizántevékenység irányítását a Partizánmozgalom Ukrán Törzsétől a 4. Ukrán Front Haditanácsa mellett müködő Partizánmozgalom Törzse vette át. A csoportokat a magyar határokhoz közelebb lévő, Sztanyiszlavtól 5 km-re fekvő opresovcei bázison összpontosították. A 4. Ukrán Front vezetése célirányosabb tevékenységet várt el a partizán egységektől, hogy a Vörös Hadsereg hadmüveleteit közvetlenebbül támogató akciókat folytassanak. Gyakran konkrét feladatokat, célpontokat, müködési körzetet jelöltek ki a számukra, és sokkal kevésbé vették figyelembe a politikai megfontolásokat, például a magyar párt vezetőinek kérését, véleményét. Miközben ROSENFELD [RÁKOSI] Mátyás egyre újabb csoportok bevetését sürgette, a 4. Ukrán Front Haditanácsának Partizánmozgalom Törzse október közepén öt, már felkészített magyar egység bevetését is leállította, mert a Vörös Hadsereg gyors elörenyomulása miatt katonai szempontból már nem látta különösebb hasznát a ledobásuknak. ${ }^{11}$

A szovjet hadvezetés 1944. augusztus végén a katonai helyzet számára kedvező alakulása, a szlovák, magyar és román határ megközelítése nyomán szükségesnek látta a magyarországi partizántevékenység fokozását, nagyobb számú ejtőernyős harci és szervező csoport ledobását. Ebben fontos szerepet játszott az 1944. VIII. 23-ai román kiugrás, amely következtében a Vörös Hadsereg váratlan gyorsasággal elérte a Kárpátokat, és megkezdte Észak-Erdély megszállását. Ennek elősegítésére, felderítési információk továbbítására, a front mögötti területek a közúti és vasúti forgalmának megzavarására, illetve jelentösebb fegyveres erő, rendfenntartó és karhatalmi egységek lekötése érdekében a korábbinál fontosabb feladatot szánt a bevetett ejtőernyősöknek. Ösztönözte a magyarországi partizánharc kiterjesztését az 1944. VIII. 29-én szovjet közremüködéssel kirobbant szlovák nemzeti felkelés is, amely az első hetekben komolyabb sikereket hozott, és azzal a lehetőséggel kecsegtetett, hogy a felkelők az ellenőrzésüket esetleg ki tudják terjeszteni Észak-Magyarország egyes körzeteire is. ${ }^{12}$

A Szovjetunióbeli magyar kommunista emigráció a korábbinál is jobban sürgette, hogy szovjet részről, elsősorban a Partizánmozgalom Ukrán Törzse nagy számban dobjon le az ország területére ejtőernyősöket (lehetőleg magyar származású partizánokat). Nem ismerve a hazai helyzetet, a lakosság tömeges csatlakozására számítottak, amit nemcsak a háború idejére tartottak volna fontosnak, hanem a háború után tervezett baloldali hatalomátvétel társadalmi támogatottságának bővítése szempontjából is. Egy esetleges sikeres kiugrás, vitéz nagybányai HORTHY Miklós vezetésével, a háború után komoly politikai tőkét jelentett volna a jobbközép erőknek, míg a kommunista partizánok tömeges részvétele a hitleri Németország elleni harcban a baloldal presztízsét erősíthette volna. Rákosi Mátyás, a kommunista párt vezetője 1944. IX. 1-jén személyesen tárgyalt a PUT parancsnokával, hogy a partizániskola magyar hallgatóiból mielőbb állítsanak fel új akciócsoportokat és vessék be azokat Magyarországon. ${ }^{13}$

\section{Partizánok Erdélyben és Kelet-Magyarországon}

A szovjet, és a velük együttmüködő román erők Észak-Erdélybe való betörése miatt a Honvéd Vezérkar 1944. VIII. 30-ai utasítása nyomán, a nagyváradi csendőr iskola (tanzászlóalj) alakulatait, a térségben állomásozó csendőr századokat, illetve az őrsök feltöltésére szánt tartalékállomány egy részét harccsoportokba szervezték, és frontális harcban vetették be a határokat átlépő ellenséggel szemben. Ehhez azonban nem kaptak páncélelhárító eszközöket, nehézfegyvereket, géppisztolyokat, hanem a közbiztonsági feladatokra szánt szabvány csendőr felszereléssel kellett volna feltartóztatniuk a Vörös Hadsereget. Ráadásul, komolyabb honvédségi tartalékok nem lévén, a csendőrséggel feltöltött egységeket részenként, kis kötelékekben vetették harcba, ami eleve lehetetlenné tette a komolyabb harcászati siker elérését. A csendőr századok elvonulásával az ország belsejében megfogyatkozott a rendvédelmi erő, amely a mögöttes területek rendjét, nyugalmát biztosítani tudta volna, és hatékonyan felléphetett volna a szélesedő partizántevékenység ellen. ${ }^{14}$

1944 augusztusban a Székely Határvadász Zászlóaljat kivitték a frontvonalba, a Keleti-Kárpátok védelmére. A magyar-román határszakasz így gyakorlatilag őrizetlenül maradt, ezért az ott lévő csendőr őrsöknek határportyázást is kellett folytatniuk. 1944. VIII. 29-én a nagyajtai csendör őrsöt (Sepsiszentgyörgy ÉNY $20 \mathrm{~km}$ ) a román területről átszivárgó partizánok megtámadták, az őrs-parancsnokot és négy csendőrt megöltek. 1944. VIII. 30-án Előpatak térségében (Sepsiszentgyörgy NY 10 km), a határ túloldalán román félkatonai erők gyülekeztek és betörésre készültek. A helyi csendőrség a sepsiszentgyörgyi szárny-parancsnok vezetésével, egy német félszázad támogatásával átlépte a határt és elfoglalta Botfalut és szétkergette az ellenséges csoportot. A sepsiszentgyörgyi szárny-parancsnok további előrenyomu- 
lásra készült a 10 km-re lévő Brassóban harcoló német erők megerösítésére, de a sepsiszentgyörgyi német parancsnokság visszarendelte. A csendőrök a zsákmányolt román fegyvereket átadták az ejtőernyős-elhárító szolgálatnak. ${ }^{15}$

Ekkor azonban már Sepsiszentgyörgy is védelemre szorult, ezért az osztály-parancsnok 35 fö csendőrt rendelt be a város védelmére, ezzel viszont tovább csökkent a térségben szétszórtan elhelyezkedő csendőr őrsök ereje. 1944. IX. 1-én Sepsiszentgyörgy-Illyefalva térségében román csapatok nyomultak be magyar területre, a betörést azonban a magyar határvédelem és a körzetben tartózkodó német erők azonnal visszaverték. A helyzetet kihasználva a Sepsiszentgyörgyöt övező erdőségekbe beszivárgó partizánok 1944. IX. 2-án benyomultak a város nyugati kerületeibe. A sepsiszentgyörgyi csendőr szárny-parancsnok a tartalékban lévő 35 fő csendőrrel, egy honvéd és két német szakasszal kiszorította őket a városból, az északnyugatra elterülő dombok közé. Ezt követően egy német páncélossal megerősítve támadást indítottak a felszámolásukra. A páncélost a partizánok aknavetőkkel mozgásképtelenné tették ugyan, de a csendőrök a honvédek és a Wermacht katonák kitartó támadása, majd az ejtőernyőselhárító szolgálat alakulatainak a hátukban való megjelenése nyomán menekülni kezdtek. Az elhúzódó tủzharcban mintegy 20-25 partizán elesett, a többiek szétszóródva a környező erdőkbe menekültek. ${ }^{\mathbf{1 6}}$

A határ térségében lévő csendőr őrsök megerösítésére a szárny-parancsnokságok a biztonságosabb belső körzetekből a személyi állomány egy részét a kritikus helyekre vezényelték át. Így a helyi erőkkel a kisebb román betöréseket általában sikeresen vissza tudták verni. Nagyobb ellenséges kötelékek benyomulása esetén pedig a csendőr századok bevonásával felállított harccsoportok kerültek alkalmazásra. A bánffyhunyadi csendőr századot 1944. IX. 3-án idősebb korosztályú honvédekkel kiegészítve, egy pót gyalog-ezrednek rendelték alá, amelyet 1944. IX. 5-én Kolozsvár közelében, az Erdőfelek községnél (Kolozsvár D $8 \mathrm{~km}$ ) betörő románok ellen vetettek be. A támadókat a harccsoport kiszorította a magyar területről. Másnap, Gyalu térségében (Kolozsvár K $18 \mathrm{~km}$ ) az alakulat támadásba ment át, és elfoglalta Hidegszamos községet, majd 1944. IX. 8-án a szomszédos Melegszamost is. Így néhány fős saját veszteséggel sikerült a román csapatokat elüzni a magyar határ közeléböl. ${ }^{17}$

A DÉKÁN szovjet ejtőernyös partizán osztag 1944. VIII. 21-én 14 fövel került bevetésre. ${ }^{18}$ Eredetileg Kárpátalja egyik fontos stratégiai pontjára szánták őket, Máramarosszigettől északra, a Királymező és a Toronyi hágó, illetve a Kőrösmező és a Tatárhágó felé vezető főutak közötti területre. A ledobás azonban ettől távol, 30 km-re, délnyugatra történt, Szaplonca térségében, a Tisza bal partján, a Partiumban. Ráadásul az ejtőernyősök két csoportban ugrottak, és egymástól nagyobb távolságra értek földet. Az erdős, sziklás terepen való földet éréskor a csoport fele megsérült, két fô pedig életét vesztette. A leszállásról a magyar szervek rövidesen értesültek és a hosszúmezői és a técsői csendőr őrsök járőrei azonnal megkezdték a kutatást. Három megsérült magyar és egy orosz partizánt néhány órán belül elfogtak a csendőrök. Másnap fogságba esett még egy magyar ejtőernyős, egy orosz és egy magyar partizánt pedig az üldözés során lelőttek. Két magyar elrejtőzött, és kivárta, hogy a front átvonuljon ezen a területen. ${ }^{19}$

Így a csoportból csak három aktív fő maradt. Leszálláskor azonban elvesztek a rádió telepei, így nem tudtak kapcsolatot teremteni a kijevi központtal. Nem találták meg a tartalék felszerelést, lőszert, robbanóanyagot, élelmiszert tartalmazó ejtőernyős zsákokat sem. A DÉKÁN szovjet ejtőernyős partizán osztag vezetője és két embere hetekig bujkált az őket kereső csendőrök és honvédek elől, illetve várták az osztagok másik felét alkotó nyolc föt, akiknek a bevetését az ő leszállásukat követő néhány napon belül tervezték. Mivel azonban DÉKÁN szovjet ejtöernyös partizán osztagtól nem érkezett semmilyen rádióüzenet, ezért az osztag másik részét nem is indították el. A DÉKÁN szovjet ejtöernyös partizán osztagtól maradványa 1944. IX. 10-ig maradt a ledobás körzetében, majd kerülve a lakott helyeket, az erdőségeken keresztül délkelet felé indultak, mert pásztoroktól, erdőmunkásoktól már értesültek róla, hogy Románia kiugrott a háborúból, és a szovjet csapatok érkezését ebből az irányból várták. ${ }^{20}$

1944 szeptember végén DÉKÁN szovjet ejtöernyős partizán osztag maradványa Bazitára (Máramarossziget DK $30 \mathrm{~km}$ ) érkezett. A helyiektől megtudták, hogy egy német tiszt jár a faluba medvére vadászni. Csapdát állítottak neki, de egy helyi román figyelmeztette, így nem sikerült elfogni. Egy nappal később csatlakozott hozzájuk egy orosz repülőhadnagy, akinek a gépét Debrecen felett lőtték le, és onnan jutott el egyedül idáig. Tovább haladva Párva közelében öt fő katonaszökevény csapódott hozzájuk, később azonban elszakadtak tölük. ${ }^{21}$ Csatlakozott viszont a csoporthoz három fö szökött hadifogoly és egy fő román katona. DÉKÁN szovjet ejtöernyös partizán osztag 40 nap alatt mintegy $110 \mathrm{~km}-\mathrm{t}$ tettek meg. 1944. X. 21én Óradna közelében találkoztak a Vörös Hadsereg csapataival. A sikeres menekülésen túl, a DÉKÁN szovjet ejtöernyős partizán osztag semmilyen számottevő tevékenységet nem tudott kifejteni. ${ }^{22}$

1944 őszén a PUT és a 4. Ukrán Front mellett az Erdélybe benyomuló 2. Ukrán Front Haditanácsa mellett müködő Partizánmozgalom Törzse is bevetett ejtőernyős csoportokat magyar területen. 
A Ż́CÓI szovjet ejtőernyös partizán osztagot 1944. IX. 12-én 11 fővel Délkelet-Magyarországon vetették be. Az osztag vezetöje 1944. IX. 10-én találkozott először beosztott embereivel. Ekkor ismertették számukra a feladatot. Sarkad térségében kerülnek ledobásra, támadást kell intézniük egy lőszerraktár ellen, majd északkeleti irányban haladva, Szeghalom-Derecske-Debrecen-Nyíregyháza térségéből kellett folyamatosan felderítési adatokat küldeniük a támadó szovjet erőkkel szemben álló németmagyar csapatok erejéröl, mozgásáról. ${ }^{23}$

A ZACCÓI szovjet ejtőernyős partizán osztag 11 főnyi tagját és felszerelését szállító PSZ-47-es repülőgép a tervezett helytől mintegy $10 \mathrm{~km}$-re, északnyugatra, a hókai rizstelep térségében (Sarkad ÉNY), rejtőzésre teljesen alkalmatlan terepen dobta le. A helyi gátőr fedezte fel a partizánok leszállását, és jelentette a sarkadi csendőr őrsnek. Az őrs jelzése nyomán azonnal mozgósították az ejtőernyős-elhárító szolgálatot, melynek következtében csendőrök, polgárörök és leventék vonultak fel az ejtőernyösök felkutatására, akikhez a gyulai helyőrség egy alakulata és egy német katonai alakulat is csatlakozott. A ZÁCÓI szovjet ejtöernyös partizán osztag rádiósnője éppen bejelentkezett, amikor rajta ütöttek a sarkadi csendőrök és tüzharcban lelőtték. Az összecsapásban elesett még két fö partizán, egy föt pedig elfogtak. A ZÁCÓI szovjet ejtőernyős partizán osztag egy részének, a helyi rizstelep csőszének közremüködésével sikerült elmenekülni az üldözők elől. A sarkadi lőszerraktár ellen tervezett akció végrehajtásával már nem próbálkoztak, hanem Vésztö-Újiráz-Derecske-Hajdúszovát irányában haladva igyekeztek kitérni az üldözőik elől. Hajdúszovát közelében azonban beleütköztek egy 40 fös német alakulatba, amellyel tüzharcot vívtak. Végül is négy fö maradt, akik a Hajdúság és a Nyírség erdőiben bujkálva várták be a szovjet csapatok érkezését. ${ }^{24}$

1944. IX. 17-én a PUT kísérletet tett arra, hogy Észak-Erdélyben nagyobb partizánbázist hozzon létre, ezért útba indították a 21 fös MALÉTER szovjet ejtöernyös partizán osztagot szervezö feladatok végrehajtására az Erdélyi-szigethegység északi nyúlványához, Élesd térségébe (Nagyvárad K $20 \mathrm{~km}$ ). A parancsnok magyar katonatiszt volt, aki májusban esett szovjet fogságba majd partizánnak jelentkezett. MALÉTER szovjet ejtőernyős partizán osztagot 1944. IX. 7-én kezdték szervezni, de a parancsnok csak az indulás elötti napon találkozott az embereivel. A 14 fő magyar és hét fö szovjet partizánból álló osztag ${ }^{25}$ feladatául szabták, hogy folytasson felderítő tevékenységet Nagyvárad térségében és a Nagyvárad-Kolozsvár müút és vasútvonal mentén. Végezzen széleskörủ agitációs munkát a lakosság körében, terjessze, hogy várható a magyar kiugrás. Szervezzen nagyobb létszámú partizán csoportot a jelentkező helyi lakosok köréből, és közremüködésükkel hajtson végre jelentősebb diverziós akciókat. ${ }^{26}$

A MALÉTER szovjet ejtöernyős partizán osztagot 2 PSZ-47 szállítógépen indították útnak. Az első gépen utazott a politikai helyettes és 11 fö magyar partizán. Az emberek többsége magyar katonai egyenruhát viselt. A pilóták a Kárpátok feletti erős szembeszél lassító hatásával nem számolva, rossz helyen, jóval a célterület elött, Debrecen és Érmihályfalva között, Nyírmártonfalva-Nyíracsád térségében dobták le az ejtőernyősöket. Ez 80 km-re, északnyugatra volt az eredeti célterülettőll. Néhány partizán Nyíracsád szélső házai közvetlen közelében ért földet, így a leszállásról azonnal tudomást szereztek a hatóságok is. A terep rejtőzésre alkalmatlan volt, a gyéren telepített kisebb erdőket a csendőrség és a honvédség könnyen át tudta vizsgálni. ${ }^{27}$

A térségben, a román határ közelsége miatt jelentős csendőr erők tartózkodtak. A VI., VII. és IX. csendör kerület öt őrse állomásozott a leszállás körzetében, $10 \mathrm{~km}$ sugarú körön belül, 58 főnyi személyi állománnyal. A csendőrök, valamint a debreceni VI. hadtest-parancsnokság által kivezényelt 44 fö magyar és 34 fö német katona azonnal támadást intézett a partizánok ellen. A földet érés után az ejtőernyősök egy kisebb erdőbe menekültek, de körülvették őket, és kézigránát esőt zúdítottak rájuk. A kialakuló tüzharcban három fö meghalt, egy főt pedig elfogtak a nyírábrányi csendőrök. Egy fö súlyosan sebesült partizánnak sikerült elrejtőznie. Öt néhány helyi lakos találta meg, és ápolta a szovjet csapatok megérkezéséig. ${ }^{28}$ A túlélők egy része északnyugat felé, Nyíradony irányába, a másik részük kelet felé, Érmihályfalva irányába menekült. Közülük a nyíradonyi csendőr őrs két fơt, az érmihályfalvi szintén két fôtt elfogott. A foglyokat átadták a nyíregyházi honvéd-parancsnokságnak. Két fö az ugrásnál északi irányban elsodródott a többiektől, így a földet éréskor már kívül voltak azon a körzeten, ahol a magyar hatóságok a partizánokat keresték. A két ejtőernyős északkelti irányban, Nyíregyháza és a Bodrogköz felé haladt. Néhány nappal később Kótalj (Nyíregyháza É 10 km) határában azonban elfogta őket a kemecsei csendőr őrs járöre. $^{29}$

1944. IX. 17-én a másik géppel került bevetésre a MALÉTER szovjet ejtőernyös partizán osztag második része két fő magyar és hét fő orosz partizánnal. Ez a gép két nagy ejtőernyős zsákban szállította a robbanóanyagot és a tartaléklőszert. Ez a repülő is eltévesztette a célt, és attól $50 \mathrm{~km}$-re, északra, Tasnád térségében dobta le az ejtőernyősöket (a másik csoporttól 60 km-re, keletre). A pilóta jelzésére először MALÉTER szovjet ejtőernyős partizán osztag parancsnoka ugrott, négy fö partizánnal, majd kidobták az 
ejtőernyős zsákokat. Ezután ugrott ki a visszaforduló gépből a fedélzeten maradt négy fő orosz partizán. Ök azonban a korábban kiugróktól távol, 25 km-re északnyugatra, Mezőpetri körzetében értek földet. A szaniszlói csendőr őrs járőrei és a nagykárolyi honvéd karhatalom azonnal keresni kezdte az ejtőernyősöket. A négy fő orosz elrejtőzött, a náluk lévő egyik rádiót és a rejtjelkulcsot megsemmisítették, nehogy a magyar hatóságok kezére jusson. Így viszont nem tudtak kapcsolatba lépni a kijevi parancsnoksággal, sem információt, sem erősítést nem tudtak kérni. Néhány nap bujkálás után északkeleti irányba indultak, hogy mielőbb találkozzanak az Észak-Erdélybe benyomuló szovjet csapatokkal. ${ }^{\mathbf{3 0}}$

A MALÉTER szovjet ejtőernyős partizán osztag parancsnokával együtt ugrók leszállása sem volt sima. Egymáshoz közel értek ugyan földet, egyikük azonban megsérült a lábán, az orvos pedig egy fára esett, és amikor levágta az ernyőjét a földre zuhant, melynek következtében hat napig nem tudott lábra állni, a társai vitték rögtönzött hordágyon. Az egyik ejtőernyős zsákot megtalálták, de nem tudták magukkal vinni a sebesült szállítása miatt, így a tartalék felszerelést elásták. A MALÉTER szovjet ejtőernyös partizán osztag 1944. IX. 17-én földet érő részének a leszállását is észlelték az ejtőernyős elhárító szervezetk, és a tasnádi csendőrség keresni kezdte öket, ezért haladéktalanul déli irányba indultak, Tasnádorbó, Oláhcsaholy, Kémer érintésével, az eredeti ledobási hely felé, ahol a nagyobb erdőség nagyobb biztonságot kínált a számukra. ${ }^{31}$

1944. IX. 21-én éjszakára utánpótlást, embereket és felszerelést kértek a kijevi parancsnokságtól. Tasnádorbó térségében jelzőtüzeket gyújtottak, de a várt repülőgép nem érkezett meg. 1944. IX. 24-én éjszaka Szilágydomoszló körzetében ismét tüzeket gyújtottak, és várták az utánpótlást. Éjfél körül, már a megbeszélt idő után megjelent egy repülőgép, de tüzet nyitott a máglyák környékére. Valószínűleg egy német éjszakai vadászrepülőgép lehetett. 1944. IX. 25-én a kémeri csendőr őrs irányításával az ejtőernyős-elhárító szolgálat és két szakasz honvéd átvizsgálta a Szilágydomoszló-Kárásztelek közötti erdőséget, de nem talált rá a partizánokra. 1944. IX. 28-án a MALÉTER szovjet ejtöernyős partizán osztag lesállást foglalt a Kémer-Bályok országút mellett, és tüzet nyitottak két arra haladó honvédségi teherautóra. A két sofört és a két kocsikísérőt megölték, és néhány harckocsi aknát zsákmányoltak. A két teherautót felgyújtották. ${ }^{32}$

1944. X. 2-án már odahallatszott a frontról az ágyútüz, amikor Bályok közelében aláaknázták a Margitta-Szilágysomlyó közötti vasútvonalat. A robbanás következtében egy Margitta felöl érkező szerelvény, egy mozdony és négy vasúti kocsi kisiklott. A pályát azonban néhány óra alatt helyreállították. 1944. X. 12-én néhány tartalékos honvéd egy csendőr parancsnoksága alatt honvédelmi munkára mozgósított 60 fös leventecsoportot kísért át a MALÉTER szovjet ejtőernyös partizán osztag által szemmel tartott területen. Az osztag tagjai lesből lelötték a csendőrt, mire a többi kísérő elmenekült. A fiatalokat a partizánok hazaküldték. 1944. X. 13-án egy német teher- és egy személyautó akadt el egy mellékút sarában. A német katonák ökröket rekviráltak egy közeli tanyán, hogy a gépkocsikat kivontassák a sárból. A MALÉTER szovjet ejtőernyös partizán osztag emberei rajtuk ütöttek, három német katonát megöltek, egy pedig elmenekült. Az autókat felgyújtották, az ökröket visszaadták a gazdájuknak. 1944. X. 15én egy leharcolt magyar zászlóalj 350 embere Kémer mellett egy tanyán állt meg pihenésre. A MALÉTER szovjet ejtöernyős partizán osztag megkereste a parancsnokot és a kormányzói kiáltványra hivatkozva rábeszélte, hogy oszlassa fel az egységet és küldje haza az embereit. A tiszt hosszabb rábeszélés után végül megtette, amit az osztag vezetöje kért. Az egység néhány tagja csatlakozott a partizánokhoz. ${ }^{33}$

1944. X. 17-én a szovjet csapatok felderítői elérték Kémer térségét. A MALÉTER szovjet ejtöernyös partizán osztag parancsnoka november elején számolt be a 2. Ukrán Front Haditanácsa mellett müködő Partizánmozgalom Törzsének a csoportjával kapcsolatos eseményekről. Ezt követően Szvjatosinora került, majd 1945 februárjában Debrecenbe küldték és kinevezték az Ideiglenes Kormány szolgálatában álló 6. örzászlóalj parancsnokává. Bevetését követően a MALÉTER szovjet ejtőernyős partizán osztag darabjaira hullott, a személyi állomány felét megölték vagy elfogták. Az együtt maradt néhány ember egy hónap alatt megsemmisített három teher- és egy személyautót, megrongált egy mozdonyt és négy vasúti kocsit, megölt három német, négy magyar katonát és egy csendőrt. Szélnek eresztettek 60 honvédelmi munkára behívott leventét és elérte, hogy egy zászlóalj maradványa, 350 ember szétszéledjen. Mindez messze elmaradt az eredeti várakozásoktól, és semmilyen befolyást nem gyakorolt a katonai helyzet térségbeli alakulására. ${ }^{34}$

A MALÉTER szovjet ejtőernyös partizán osztag parancsnok-helyettese részletes jelentést készített azokról az okokról, amelyek akadályozták, hogy az osztag sikeresen múködjön. Megállapította, hogy hiányos volt a gyorstalpaló kiképzés, a bevetésre kerülő partizánok nem rendelkeztek ejtőernyős gyakorlattal, ezért sokan megsérültek a leszállásnál. Pontatlanul navigáltak a szállítógépek, és rosszak, elavultak voltak a kiosztott térképek. A magyar kommunisták által ígért összekötő személyek, akik kalauzolták volna a földet érő ejtőernyősöket, nem jelentkeztek. A több részletben való ledobás nem vált be, 
az osztag nagy területen szétszóródott. Rossz volt a málházás, ezért a felszerelés nagy része elveszett. A fegyverek vadonatújak voltak ugyan, de nem kerültek belövésre, így csak a bevetésen derült ki, hogy egy részüket nem lehet használni. A fözésre adott élelmiszerek gyakorlatilag ehetetlenek bizonyultak. ${ }^{35}$

Mivel a DÉKÁN szovjet ejtőernyős partizán osztagtól 10 nappal a földet érés után sem érkezett semmilyen jelzés, a PUT parancsnoksága 1944. IX. 1-jén úgy döntött, hogy az osztag Sztanyiszlavban maradt másik részlegéből egy önálló osztagot szervez, ez volt a RIESDORFER szovjet ejtöernyös partizán osztag. Ebbe az osztagba nyolc magyar és öt szovjet partizán került. ${ }^{36} \mathrm{~A}$ fegyverzetet 11 géppisztoly, egy golyószóró, két pisztoly, 24 gránát, 6000 géppisztoly és 1500 golyószórótöltény, valamint két rádiókészülék (egy PRO és egy Szever) alkotta. Bevetésüket Aknasuhatag (Máramaroszsiget D $15 \mathrm{~km}$ ) mellett, egy viszonylag biztonságos körzetben tervezték, 40-45 km-re, délre attól a helytöl, ahol DÉKÁN szovjet ejtőernyös partizán osztagnak földet kellett volna érni. Feladatuk szerint Máramarossziget-Szaplonca-Pálosremete térségében kellett tevékenykedniük, felderítést végezni, a helyi lakosok beszervezésével egy nagyobb partizánbázist kiépíteni, ahová újabb ejtőernyős csoportok és hadianyag érkezhetett volna, illetve diverziós akciókat végrehajtani katonai létesítmények, a Máramarosszigetről Huszt felé vezető vasút és a Szatmárnémetibe vivő fơútvonal ellen. Külön utasítást kaptak, hogy próbálják felderíteni mi történt a DÉKÁN szovjet ejtőernyös partizán osztaggal és igyekezzenek felvenni vele a kapcsolatot. Ledobásukra végül 1944. IX. 20-án éjszaka került sor, nagyjából a tervezett körzetben. A leszállásnál három fö megsérült. Az egyikük súlyos állapotba került, akit csak 1944. IX. 23-án találták meg a többiek. Mivel nem tudott járni egy pásztorkunyhóban helyezték el, ott maradt egészen a szovjet csapatok beérkezéséig. ${ }^{37}$

Időközben azonban a hatóságok tudomást szereztek a RIESDORFER szovjet ejtőernyös partizán osztag müködéséről és kutatóakciót indítottak. Ebben elsősorban a helyileg illetékes három csendőr őrs személyi állománya vett részt. Miután azonban a partizánok tartózkodási helyét sikerült lokalizálni, elfogásukra kivezényelték az aknaszlatinai csendör század egyik szakaszát. Több alkalommal került sor tüzharcra a partizánok és a csendőrség, illetve a mozgósított ejtőernyős-elhárító szolgálat keresőcsoportjai között. A nehézzé vált helyzetben a partizánok igyekeztek kitérni az üldözők elől, és az északkeletre elterülő erdökön keresztül Szaplonca irányába indultak. Menet közben kisebb rajtaütéseket hajtottak végre fatelepek, illetve az erdei utakon közlekedő jármüvek ellen. ${ }^{38}$

1944. X. 1-jén a RIESDORFER szovjet ejtőernyös partizán osztag parancsnokát rádión arról tájékoztatták, hogy felsőbb irányításukat a 4. Ukrán Front Haditanácsa mellett müködő Partizánmozgalom Törzse veszi át. 1944. X. 2-án az osztag felderítői nyolc fő fegyvertelen katonaszökevénnyel találkoztak az erdőben. Közülük három fö hajlandó volt csatlakozni az osztaghoz, a többiek viszont csak haza akartak menni. Az osztag 1944. X. 8-án engedélyt kapott a Partizánmozgalom Tőrzsétől, hogy korábbi kérésüknek megfelelően az osztag felvegye a „RAKOSI partizáncsoport” nevet. Másnap az a parancs érkezett a 4. Ukrán Fronttól, hogy mielőbb vonuljanak Beregszász körzetébe és ott építsenek ki bázist, ahová az utánpótlást ledobják majd a számukra. Beregszász azonban az aktuális tartózkodási helyüktől 90-100 km-re volt, RIESDORFER szovjet ejtőernyös partizán osztag parancsnoka nem látott reális esélyt arra, hogy eljussanak odáig. A csoportban már korábban is jelentkezett bizonyos feszültség a magyar és a szovjet partizánok között. Az osztag parancsnoka az eredeti elképzeléseknek megfelelően Szaplonca térségébe igyekezett, a szovjetek mielőbb Beregszász közelébe akartak eljutni, hogy a Kárpátokon átkelő Vörös Hadsereggel hamarabb találkozhassanak. ${ }^{39}$

1944. X. 9-én a máramarosszigeti csendőr őrs, az aknaszlatinai csendőr század 1. szakasza és egy honvéd szakasz Máramarosszigettől délnyugatra, 25 km-re, Fernezely közelében megtámadta a partizánokat. A táborban csak a szovjetek voltak, éppen rádióadáshoz készültek. Az összecsapásban egy partizán elesett és a csoport rádiója a csendőrség kezébe került. Az osztag másik része ekkor tért vissza a felderítésböl. Váratlan megjelenésük megzavarta a katonákat és csendőröket, a szovjetek így ki tudtak törni a bekerítésből. Az összecsapásban a magyar partizánok közül egy fó életét vesztette, egy fö pedig súlyosan megsebesült. Öt a helyi lakosok gondjára bízva hátrahagyták. A partizánok harc közben elfogtak a viski csendőr örsön szolgálatot teljesítő egy fö próbacsendőrt, akit lefegyvereztek, de végül elengedtek, hogy ezzel próbálják javítani a partizánokról a lakosság körében kialakult ellenséges képet. Az összecsapás nyomán a partizán osztag kettészakadt. Négy fö orosz partizán északkelet felé indult, Beregszász felé. 1944. X. 13-ig azonban csak Pálosremetéig jutottak, ott elrejtőztek és kivárták a szovjet csapatok megérkezését. ${ }^{40}$

A RIESDORFER szovjet ejtőernyös partizán osztag így öt före olvadt. A fegyverzetük egy golyószóró, négy géppisztoly, egy pisztoly, hat kézigránát, 1200 géppisztoly- és 200 golyószórótöltény volt. 1944. X. 20-án csapattestétől leszakadt 17 bujkáló magyar honvéd csatlakozott a RIESDORFER szovjet ejtőernyős partizán osztaghoz. A létszám ezzel 22 före nőtt, gyarapodott a fegyverzetük is két 
golyószóróval, nyolc géppisztollyal, 17 puskával, nyolc pisztollyal, 24 kézigránáttal, 1500 géppisztolyés 1130 puskatölténnyel rendelkeztek, fegyveres akcióra azonban nem vállalkoztak. A RIESDORFER szovjet ejtőernyős partizán osztag egy hónapos tevékenysége, minden jelentősebb eredmény nélkül 1944. X. 24-én ért véget, amikor csatlakoztak a szovjet csapatokhoz. ${ }^{41}$

A különböző szovjet partizántörzseknek többszöri próbálkozás ellenére Észak-Erdélyben, a Partiumban vagy Kelet-Magyarországon nem sikerült komolyabb bázist kiépíteni, és jelentősebb gerilla tevékenységet szervezni. A lakosság, magyarok, és románok is, idegenkedve fogadták a szovjet ejtőernyősöket, csak ritkán támogatták őket. Erdély 1944 nyaráig a szovjet hadászati tervek szempontjából viszonylag félreeső helynek számított. Amikor pedig 1944 augusztusában már megnőtt a hadmüveleti jelentősége, a román átállás miatt a Vörös Hadsereg egyetlen hónap alatt elérte és megszállta ezt a területet.

\section{Partizánháború Kárpátalján}

Kárpátalja területén 1944 augusztus végén két olyan körzet volt, ahol a szovjet partizánok meg tudták vetni a lábukat. Az egyik körzet, ahol a partizánok be tudtak rendezkedni, a Borló-hegység volt, Munkács KÉK 30-40 km). A szintén nehezen járható, sürü erdővel fedett terepen USZTA szovjet ejtöernyös partizán osztag és a PRISCSEPA szovjet ejtöernyös partizán osztag müködött. A USZTA szovjet ejtöernyős partizán osztag sikerét az óvatos, rejtőzködő taktikának köszönhette. A leszállást követő másfél hónapban, amíg meg nem tudta növelni a létszámát és jelentősebb hadianyag utánpótlást nem kapott, jelentősebb fegyveres akciót sem hajtottak végre, így a rendvédelmi szervezetek hosszabb időn át nem indítottak ellene átfogó tisztogató akciót. Később pedig, amikor fokozódott az aktivitása, a katonai helyzet már nem tette lehetővé, hogy elegendő fegyveres erőt összpontosítsanak a felszámolására. ${ }^{42} \mathrm{~A}$ másik terület a Róna-havas térsége volt, ahová a nyár folyamán több szovjet ejtőernyős partizán osztag is érkezett. Közülük a TKANKO szovjet ejtöernyös partizán osztag bizonyult a legsikeresebbnek, amely a Róna-havas északi körzetében részben szlovák területre átnyúlva (Munkács É 40-50 km, Ungvár É 30-40 km) rendezkedett be. Az osztag kezdetben alapvetően felderítő tevékenységet folytatott, majd kisebb támadásokat hajtott végre, egymástól távolabb eső körzetekben. Az akciók után a partizánok nehezen járható, lakatlan területekre húzódtak fel a hegyekben, ami megnehezítette a magyar hatóságok, a rendvédelem, a csendőrség gyors és hatékony fellépését velük szemben. ${ }^{43}$

A Partizánmozgalom Ukrán Törzse 1944. VIII. 8-án éjszaka vetette be Kárpátalján 14 fös USZTA szovjet ejtőernyős partizán osztagot. ${ }^{44}$ A osztag feladata a Munkács térségében zajló katonai mozgások felderítése, a helyi, elsősorban ruszin lakosság körében végzett agitációs munka, további csoportok fogadására alkalmas tábor kiépítése volt, valamint fegyveres rajtaütések végrehajtása a Munkács-Szolyva és a Munkács-Huszt közút és vasútvonal körzetében. Az osztag Munkácstól délre ért földet. A leszállásnál egy fö partizán súlyosan megsérült, mozgásképtelen volt. Az osztag parancsnoka későbbi nyilatkozatai szerint öt magára kellett hagyniuk, hogy elmenekülhessenek az üldözők elől, a sérült partizán pedig öngyilkos lett, hogy ne kerüljön fogságba. Az esetről készült hivatalos hatósági jelentés szerint viszont a sérült partizánt a társai lőtték agyon. ${ }^{45}$ A leszállást követően az USZTA szovjet ejtőernyős partizán osztag átvonult a Munkácstól 20-30 km-re, keletre elterülő Borló-hegységbe, melynek sürủ erdői, és magasabb csúcsai (Buzsora 1086 m, Mártonkő 967 m) megfelelő rejtekhelyet, bázisépítési lehetőséget kínáltak. Az osztag parancsnoka rendkívül óvatos volt, föként a szervezésre és elökészítésre, szélesebb civil támogató bázis kiépítésére koncentrált, és heteken át kerülte a fegyveres összecsapásokat. ${ }^{46}$

1944. VIII. 25-én erősítést küldtek az USZTA szovjet ejtőernyős partizán osztag számára. Ekkor dobták le ejtőernyővel az osztag második részét, összesen kilenc föt. ${ }^{47}$ Földet éréskor négy fő megsérült, közülük két fő súlyosan, egy fő pedig eltűnt. Ugyanekkor a PRISCSEPA szovjet ejtőernyös partizán osztagot is bevetettek, melyet az az USZTA szovjet ejtöernyös partizán osztag kellett volna fogadnia, hogy utána megkezdjék önálló feladatuk végrehajtását. A PRISCSEPA szovjet ejtőernyős partizán osztagot két géppel érkezett. Az egyik azonban a célterület közelében lezuhant, négy fös személyzete, valamint a PRISCSEPA szovjet ejtöernyős partizán osztagnak 10 fö tagja életét vesztette. A másik gépről az osztag 13 tagja ugrott. ${ }^{48}$ Az ugrás során azonban többen súlyosan megsérültek, egy időre mozgásképtelenné váltak, köztük az osztag parancsnoka is. A szétszóródott osztagból a következő napon négy föt a hátmegi csendőr őrs járőrei elfogtak. ${ }^{49}$

PRISCSEPA szovjet ejtöernyös partizán osztag gyakorlatilag megsemmisült, maga a parancsnok is ápolásra szorult. Ezért megmaradt embereivel csatlakozott az USZTA szovjet ejtöernyös partizán osztaghoz. A közös létszám 31 fő volt (17 magyar, 14 orosz, ukrán, ruszin). A fegyverzetüket két golyószóró, 28 géppisztoly, egy távcsöves puska, öt pisztoly, 30 kézigránát, 6000 géppisztoly- és 1000 puskatöltény alkotta. A honvédség és a csendőrség ismétlődő kereső akciói miatt a partizánoknak állandó mozgásban kellett lenniük. USZTA szovjet ejtőernyös partizán osztag rádión kérte a PUT illetékeseitől, hogy mielőbb 
küldjenek ellátmányt és hadianyag utánpótlást, mindenekelőtt robbanószert, ha komolyabb akciókat várnak tőlük, a PUT vezetője és a szvjatosinoi táborba érkező ROSENFELD [RÁKOSI] Mátyás azonban bizalmatlanok voltak. A PRISCSEPA szovjet ejtöernyös partizán osztag parancsnokának jelentkezését sürgették, hogy ő is erösítse meg az USZTA szovjet ejtöernyös partizán osztag állításait, mivel nem akarták megérteni, hogy a PRISCSEPA szovjet ejtőernyös partizán osztag tulajdonképpen megsemmisült és a rádióját is elveszítette, így nem tudja szabály szerint felvenni a kapcsolatot Kijevvel. ${ }^{\mathbf{5 0}}$

1944. IX. 5-én a PUT végre tudomásul vette, hogy a PRISCSEPA szovjet ejtöernyös partizán osztag maradványai beolvadtak az USZTA szovjet ejtöernyős partizán osztagba. Ettől kezdve Kijev is közös egységként kezelte őket. 1944. IX. 6-án az USZTA szovjet ejtőernyős partizán osztag parancsnoka arról tájékoztatta a PUT parancsnokát, hogy az alakulat felvette a „Rákóczi osztag” nevet. A személyi állomány ekkor 43 főből állt (17 magyar és 26 szovjet). A fegyverzetet két golyószóró, 30 géppisztoly,ókilenc puska, öt pisztoly, 30 kézigránát, 6000 géppisztoly- és 1000 puskatöltény alkotta. Az osztag a törzsre, három szakaszra (egyenként három rajjal) és egy robbantócsoportra tagolódott. ${ }^{51}$

USZTA szovjet ejtöernyös partizán osztag parancsnoka további hadfelszerelést, fegyvert, löszert és föként robbanóanyagot kért a PUT-tól, hogy diverziós akciókat hajthasson végre. A PUT parancsnoka azonban közölte vele, hogy egyelöre nem tud utánpótlást küldeni, a partizánok szerezzenek fegyvert és löszert az ellenségtől. Egyben arra utasította az osztag parancsnokát, hogy a jelenlegi bázisukról, a Buzsorától vonuljanak mintegy 100-120 km-re, délnyugatra, Debrecen körzetébe, és ott fejtsenek ki aktív tevékenységet. A PUT parancsnoka szerint a nyírségi erdők tökéletesen alkalmasak ilyen feladatra. A parancs a magyar kommunista vezetés, ROSENFELD [RÁKOSI] Mátyás kérésére született, aki mielöbb szeretett volna kommunista partizánokat látni Magyarország belső körzeteiben. Az USZTA szovjet ejtőernyős partizán osztag parancsnoka azonban a háború elött erdész volt, pontosan ismerte, hogy a Debrecentől északkeletre elterülő rendezett, kisebb részekre tagolt, jól áttekinthető erdők nem nyújtanának kellő fedezéket az osztaga számára, ezért nem hagyta el a Buzsorát. Az első felháborodás után a PUT vezetése is belátta, Debrecen szükebb körzete nem alkalmas a partizánharcra, ezért elfogadták, hogy az USZTA szovjet ejtöernyős partizán osztag parancsnoka a továbbiakban a Buzsora térségében fog tevékenykedni. ${ }^{52}$

Az USZTA szovjet ejtöernyős partizán osztag a következő napokban biztonságos táborhely és tartalékbázis kiépítésével, illetve bővítésével foglalkozott. Felderítők járták a környéket és összegyüjtötték más, korábban szétvert partizán osztagok bujkáló embereit, szökött szovjet hadifoglyokat, magyar és ruszin származású katonaszökevényeket, lelőtt szovjet gépek személyzetét. A Borló-hegység körzetében lévő települések lakossága körében élénk agitációs munkát folytattak. Erre a feladatra az osztag politikai helyettesének vezetésével 16 magyar és ruszin propagandistát állítottak rá. 1944 szeptember közepére az osztag létszáma közel 94 főre emelkedett, közte 21 magyar, 12 ukrán és ruszin, 42 orosz, szovjet. Az újonnan toborzottak közül azonban nem volt mindenkinek fegyvere. ${ }^{53}$ Mivel az osztag parancsnoka egyre csak sürgette az utánpótlást, 1944. IX. 10-én a PUT parancsnoka minden alárendelt szovjet ejtőernyős osztag parancsnok számára rádióüzenetet küldött — ami elsősorban az USZTA szovjet ejtőernyős partizán osztag parancsnokának szólt —, hogy ne kérjenek állandóan hadianyagot Kijevtől, mert egy partizán osztagnak az a dolga, hogy az ellenségtől zsákmányoljon mindent, amire szüksége van. Másnap azonban az USZTA szovjet ejtöernyös partizán osztag parancsnoka ismét utánpótlást kért tőle, közölve, hogy ha Kijev hatékony akciókat akar, akkor küldjön hozzá hadianyagot. 1944 szeptember első két hetében az USZTA szovjet ejtöernyös partizán osztagnak egyik fö tevékenysége az élelmiszer biztosítása volt, amelyet a környezö falvakban gyüjtöttek be. 1944. IX. 13-án Kenézpatak és Kisábránka községekben rekviráltak nagyobb mennyiségü élelmiszert. ${ }^{54}$

A kijevi elvárásokra válaszul, és hogy a helyi lakosság körében is tekintélyt teremtsen az osztag több, katonailag jelentéktelen, de látványos diverziót hajtott végre. 1944. IX. 15-én - egy hónappal a földre szállás után - került sor az osztag első fegyveres akciójára. Az osztag felderítő csoportja jelentette, hogy Kereckén a csendőr őrs épülete könnyen megközelíthető helyen áll, és az őrsről állományának fele szinte folyamatosan távol van, járörszolgálatot teljesítése céljából. Az osztag parancsnoka a második szakaszt 39 fővel küldte Kereckére. A partizánok sötétedés után támadták meg az épületet. A kialakuló tüzharcban két csendőr elesett, a többiek elhagyták az őrsöt és visszavonultak. A harcban két partizán megsebesült, a többiek pedig összetörték a berendezést és az iratokat elégették. ${ }^{55}$ 1944. IX. 16án a USZTA szovjet ejtöernyös partizán osztag mintegy 30-40 fős 1. szakasza megtámadta a Kereckétől 10 km-re, északnyugatra fekvő Zajgó községet. Elvágták a telefon és távíróvezetékeket, élelmiszert rekviráltak a lakosságtól. Öt fő betört a községházára, elvitték a nemzetőrség ott tárolt fegyvereit, négy puskát, a körjegyzőt pedig megölték. Ezt követően, az onnan északnyugatra fekvő Havasalja községnél, a Szolyvára vezető út mentén az osztag 1. szakasza 38 emberrel lesállást foglalt. Hamarosan egy személy- és egy teherautó érkezett, melyekre a partizánok tüzet nyitottak. Egy német és két magyar tiszt, 
valamint négy katona meghalt, hat fö fogságba esett, a két autót és a 800 liter üzemanyagból álló rakományt felgyújtották. ${ }^{\mathbf{5 6}}$

A támadó akciók mellett az USZTA szovjet ejtőernyős partizán osztag kisebb különítményei folyamatosan járták a környéket, hogy élelmet szerezzenek. Az élelmiszerellátás volt az egyik legnagyobb probléma, különösen a létszám további növekedése nyomán. 1944. IX. 17-én Lombos községben (Szolyva DK 6 km), Zajgó szomszédságában három partizán lefegyverezte az egyetlen rendvédelmi tényezőt, az erdőőrt, és élelmiszert, pokrócokat vittek el a faluból. Ugyanezen a napon onnan délnyugatra, 12 km-re Gálfalva községben (Munkács K $15 \mathrm{~km}$ ) is megjelent az osztag másik kislétszámú különítménye és élelmet rabolt. A felbukkanó községi nemzetörökre rálőttek, de utána gyorsan eltávoztak. ${ }^{57}$ 1944. IX. 18-án az osztag egyik ugyancsak kislétszámú különítménye Rókamezőn (Kerecke ÉK $5 \mathrm{~km}$ ) rekvirált élelmiszert. Közben folytatódtak a kisebb rajtaütések, melyeket nem a honvédség által bekerített területen, hanem a gyürü külső oldalán hajtottak végre. 1944. IX. 19-én Havasalja közelében 30-40 partizán megtámadott egy élelmet szállító magyar teherautót. A sofört megsebesítették, a kocsikísérő honvédet lefegyverezték és a rakománnyal együtt elhurcolták, a teherautót felgyújtották. ${ }^{58}$

1944. IX. 18-án Kárpátalja katonai parancsnoka a Buzsora körzetében ismétlődő kisebb támadások nyomán két gyalogezredet vezényelt a térségbe, amelyek megszállták a Borló-hegység körüli falvakat, hogy elzárják a partizánok élelmiszerforrását. Átfésültek több erdőrészt, több alkalommal is próbáltak csapdát állítani, de USZTA szovjet ejtőernyös partizán osztag északabbra húzódott, így nem sikerült felszámolni őket. Mivel az akció jelentősebb eredményt nem hozott, és a partizánok más körzetbe húzódva továbbra is zaklatták a lakosságot, a honvéd alakulatokra pedig szükség volt a fronton, ezért egy hét múltán a zárlatot feloldották. ${ }^{59}$

A PUT azonban továbbra sem volt elégedett USZTA szovjet ejtöernyös partizán osztag tevékenységével és komolyabb eredményeket követelt, nagyobb csapásokat, szélesebb körü agitációt, hogy vegyenek rá magyar katonai egységeket az átállásra, és fordítsák őket a németek ellen. Mindez a magyar kommunista vezetés téves információin alapult, akik arról győzködték a PUT vezetését, hogy elég egy szikra, egy kis agitáció és a németek iránt ellenérzéseket tápláló magyar katonák tömegesen állnak át szovjet oldalra. Ez azonban messze állt a valóságtól. A nagyobb támadásokhoz az osztag parancsnoka megint csak utánpótlást kért, főként robbanóanyagot, és ennek szükségességét végre a PUT is belátta. 1944. IX. 20-án az utánpótlás küldésének tervezett napján az osztag-parancsnok rádión arról tájékoztatta PUT vezetését, hogy a hadianyag ledobásának korábban egyeztettet, este 21 és 22 óra közötti időpontját változtassák 02 és 03 órára, mert a gyakori szovjet berepülések miatt az esti időszakban a német éjszakai vadászok cirkálnak Ungvár és Munkács térsége felett. ${ }^{60}$

1944. IX. 20-án az USZTA szovjet ejtöernyös partizán osztag a kereckeihez hasonló akcióra készült, csak most a Borló-hegység déli oldalán. A felderítők jelentették, hogy Hátmegen, a község temploma védőszentjének ünnepét tartják, támadásra nem számítanak, mert a honvédség gyürüje elválasztja a települést a partizánok feltételezett bázisától. Az este folyamán az osztag 35 fös különítménye megtámadta a csendőr őrsöt. A partizánok kézigránátokat dobtak be az ablakon és automata fegyvereikből tüzet nyitottak. A csendör őrsön tartózkodó erdőmérnök meghalt, három csendör, köztük az őrs-parancsnok megsebesült, de felvették a harcot. A tüzharcban az osztag politikai helyettese fejsérülést szenvedett. A támadók gyorsan belátták, hogy ezúttal nem érnek el sikert, így rövidesen visszavonultak. ${ }^{61}$

1944. IX. 21-én nagyszámú partizán szállta meg Kismártonka községet (Szolyva KDK 6 km), és annyi élelmiszert szedtek össze, amennyit csak tudtak, majd visszahúzódtak az erdőbe. Az osztag egy másik különítménye ugyanebben az időben, de onnan 30 km-re, keletre Vucskómezőnél (Ökörmezö D $10 \mathrm{~km}$ ) szintén élelmet próbált szerezni, amikor beleütközött egy három fős honvédjárőrbe. A katonák gyorsan reagáltak, két partizánt lelőttek, egy főt elfogtak, a többi négy-öt partizán elmenekült. ${ }^{62}$

Az USZTA szovjet ejtöernyős partizán osztag egy másik, mintegy 40 fönyi különítménye — az osztagon belüli hadrendi besorolás szerint a 2. szakasz - ugyanebben a körzetben, a Husztról a Toronyi- és a Vereckei-hágó, illetve az Árpád-vonal felé vezető úton telefonpóznákat döntött ki, hogy megszakítsa az összeköttetést. Az esti órákban, Gombástelep határában (Ökörmezö D $5 \mathrm{~km}$ ) a partizánok rajtaütöttek egy menetszázadon, mely néhány kiskaliberü lóvontatású hegyiágyúval rendelkezett. A partizánok lesből nyitottak tüzet és kézigránátokat dobtak a katonákra. A honvédek viszonozták a tüzet és visszavonulásra kényszerítették a partizánokat. A század komoly veszteségeket szenvedett, 18 katona elesett, vagy súlyosan megsebesült, a könnyebb sérültek száma 17 fö volt. Több embert veszítettek a partizánok is. Az USZTA szovjet ejtöernyös partizán osztag egy másik különítménye — az osztagon belüli hadrendi besorolás szerint az 1. szakasz - ugyanebben az időben, Havasalja térségében aláaknázta az országutat. Két katonai teherautó érkezett, az egyik aknára futott, a másik nekiütközött és felborult. A rajtuk lévő katonák azonban felvették a harcot, a partizánok rövid idő múlva kénytelenek voltak visszavonulni. ${ }^{63}$ 
1944. IX. 21-én az USZTA szovjet ejtőernyős partizán osztag létszáma nyolc tiszt és 89 fö legénység volt, (59 orosz (szovjet), 15 ukrán, 23 magyar). A fegyverzetet két golyószóró, 44 géppisztoly, 11 puska, hét pisztoly, 25 kézigránát, 20000 géppisztoly- és 8000 puskatöltény, valamint $225 \mathrm{~kg}$ trotil alkotta. Az osztag három rádiókészülékkel rendelkezett. Ekkor csatlakozott az osztaghoz két repülőtiszt, akiknek a gépét ebben a térségben lőtték le. Mivel nekik volt a legmagasabb katonai rangjuk, ezért őket nevezték ki az osztag 1. és 2. szakaszának parancsnokává. A 3. szakasz parancsnoka változatlan volt. Az osztag tagjai egyharmadának nem volt fegyvere, ezért a három szakaszból rendszeresen csak kettő került bevetésre, a többiek egyéb feladatokat láttak el. ${ }^{64}$

1944. IX. 23-án éjszaka az osztag légi utánpótlást kapott, 11 ejtőernyős zsákot dobtak le számára, közte nagyobb mennyiségủ robbanóanyaggal. A géppel két tiszt is érkezett, az egyikőjükre azonnal rátaláltak a partizánok, a másik tiszt azonban eltünt az ugrás során. Másnap éjszaka további hadianyag érkezett volna, de az osztag-parancsnok délután lemondta a repülöt, mert a térségben rosszra fordult az időjárás, zuhogott az eső és viharos szél fújt. Az osztag folytatta az élelmiszer és meleg ruha rekvirálását a fegyveres erővel nem rendelkező kis hegyi falvakban. 1944. IX. 24-én Gombosteleken jelent meg 1520 partizán ezzel a céllal. ${ }^{65}$ 1944. IX. 25-én az egy hete a Buzsora környékét megszállva tartó honvéd erők távozása után Oláhcsertészre is bement 10-15 partizán élelmiszerért. A hátmegi csendőr őrs megerősített járőre azonban időben a helyszínre ért és rajtaütött a garázdálkodókon. A tüzharcban három partizán meghalt, két fö megsebesült. A csendőröknek egy fö sebesültjük volt. 1944. IX. 28-án, az idöjárás jobbrafordulásával az osztag újabb szállítmányt kapott repülőn, 10 géppisztolyt, 10 puskát, 40 kézigránátot, 6300 puskatöltényt és $225 \mathrm{~kg}$ robbanóanyagot. Az utánpótlás ellenére az osztagnak még mindig volt vagy 20 katonája, akinek nem tudott fegyvert adni. ${ }^{\mathbf{6}}$

1944. IX. 28-án késő este osztag két felderítője azt a hírt hozta, hogy a leharcolt 357 . német gyaloghadosztály egyes részeit pihenésre, feltöltésre ebben a térségében helyezték el, és be fogják vetni azokat egy partizánok elleni tisztogató akcióra. A német egységeket Kislécfalva, Bábakút, Ivaskófalva, Kisábránka, Végmártonka területére szállásolták be, miközben magyar katonai alakulatok vonultak be Ilosva, Boród körzetében. Mozgósították a térségben lévő csendőr őrsök személyi állományát, és az utak lezárásához az ejtőernyő-elhárító szolgálat egységeit is. 1944. IX. 29-én Oláhcsertész határában a hátmegi csendőr őrs járőre és a partizán osztag egy felderítő raja között tüzharc bontakozott ki, amely során egy fő partizán meghalt. A csendőrök ezúttal lesállást foglaltak a település mentén húzódó erdő szélén. A négy fős partizán különítmény biztonságban érezve magát óvatlanul közeledett, amikor a csendőrök megadásra szólították fel őket, majd miután a partizánok a fegyverükhöz kaptak, tüzet nyitottak rájuk. ${ }^{67}$

A várható katonai tisztogató akció ellenére a partizán osztagnak nemigen volt választása, az adott terület egy jól védhető, biztos hátországot jelentett a számára. Néhány nap alatt minden felszerelésével együtt nem tudott volna más hasonló helyre áttelepülni. Ezért elhatározta, hogy felveszi a harcot. A taktikai elképzelése az volt, hogy a délnyugati irányból (Ivaskófalva, Kisábránka, Végmártonka felől) várható támadással szemben a jobbszárnyon az osztag 1 . szakasza, a balszárnyon pedig a 2. szakasza rendezkedik be védelemre. Középen a 3 . szakasz elöretolt állásban várakozott volna, mely elöször ütközött volna meg a támadókkal, majd visszavonulva a másik két szakasz tüzébe kellett volna csalnia az ellenséget. A partizán osztag parancsnoka azt remélte, hogy a kemény ellenállás, és a támadóknak okozott komolyabb veszteség visszavonulásra készteti a német-magyar eröket, és a front gyors közeledésére való tekintettel egyszerúen tudomásul veszik, hogy a Borló-hegység erdőibe végképp berendezkedtek a partizánok. Az osztag parancsnoka elküldte egyik emberét a Borló északi peremén müködő akciócsoportjához, hogy kölcsönösen segítsék egymást. Az akciócsoport parancsnoka azonban visszaüzent, hogy ellenük is támadás készül, a Munkács és Szolyva közötti falvakba (Újtövisfalva, Kishídvég, Ormód, Kislécfalva) honvéd és csendőr egységeket vontak össze, ha azok akcióba kezdenek, akkor nem tudnak segítséget nyújtani. ${ }^{68}$

1944. X. 1-jén indult meg a német akció. A partizánok számottevő saját veszteség mellett két támadást visszavertek, de így is nehéz helyzetbe kerültek. A legjobb pillanatban érkezett meg Ruszin akciócsoport egy nagyobb létszámú egysége, amely Kisábránka térségében aknavetőkkel és automata fegyverekkel hátba támadta a német csapatokat. Így az a látszat alakult ki, hogy a körzetben további jelentős partizán erők vannak. A német és magyar csapatok beszüntették a támadást, és néhány napon belül elvonultak Ilosva felé. A Huszt-Beregszász és a Huszt-Ökörmezö útvonal mentén azonban továbbra is jelentősebb katonai erők állomásoztak, ezért az USZTA szovjet ejtőernyős partizán osztag tábort váltott és a Borló-hegység északi körzetébe vonult. A katonai akció kudarca után ismét csak a szétszórt és kis létszámú csendőr őrsökre maradt a feladat, hogy az egyre nagyobb partizáncsoportokkal szemben próbálják megvédeni a közrendet és a vagyonbiztonságot. ${ }^{69}$ 
Miután az USZTA szovjet ejtőernyős partizán osztag rendezte a sorait, kisebb különítményekkel folyamatos támadásokat indított, föként a vasúti és közúti közlekedés megzavarására. A rajtaütéseket egymástól távolabbi pontokon hajtották végre, ez megnehezítette az elhárítást, illetve a partizánok központi táborhelyének beazonosítását. Az USZTA szovjet ejtőernyős partizán osztag parancsnoka egy különítményt (az osztag 1. szakaszát) a Beregszászi járásba küldte, egy másik különítmény pedig (3. szakasz) az Ilosvai járásba indult, egy további különítményt a Huszti járásban vetettek be, ezen felül egy újabb különítmény Munkács körzetébe vonult, a Ruszin szovjet ejtöernyős partizán osztag támogatására egy különítmény a Munkács-Szolyva útvonal mentén helyezkedett el. 1944. X. 4-én a beregszászi járásba küldött különítmény egyik raja aláaknázta az Ilosva-Beregkisfalud keskenynyomtávú vasút egy szakaszát a partizán osztag táborától $25 \mathrm{~km}$-re, délre. A robbanás nyomán egy mozdony és öt vagon megsemmisült. A pályát másnapra helyreállították. Ezért 1944. X. 6-án, az előző helytől nyugatra, mintegy négy km-re Beregkisfalud és Beregkövesd között újabb robbantást hajtottak végre, ezúttal egy élelmiszerszállító szerelvény mozdonyát és két kocsiját siklatták ki. ${ }^{70}$

A partizán osztag 1. szakasza még távolabbi célpontot választott. 1944. X. 4-én este a tábortól 40 km-re, délre, Bene község mellett aláaknázta a Beregszász-Tiszaújlak vasútvonal egyik nyolc méter hosszú hídját. Az őrség két tagját megölték. A 136. sz. tehervonat 03.10-kor ért a hídra. A töltet felrobbanása nyomán a sínpálya két méter hosszan felszakadt, a mozdony kisiklott néhány vasúti kocsi megrongálódott, személyi sérülés nem történt. Ugyanez a partizán különítmény nem messze a hídtól egy másik ponton is alá aknázta a síneket. Az 1944. X. 5-én délelőtt a vasúti híd kijavítása után elindított üres próbaszerelvény elöl futó tehervagonja alatt robbant a 2. akna, a vagon tönkre ment, a mozdonyt nem érte kár. A pályaszakasz javítását 17 órára befejezték, a két robbantás ellenére a forgalom csak 16 órát szünetelt. A partizán osztag parancsnoka a PUT számára készített jelentésében jelentősen eltúlozta a sikert, egy mozdony és 30 vagon megsemmisüléséről beszélt, nagyobb számú áldozatról, és állítása szerint a vasúti közlekedésben öt napos fennakadás keletkezett. ${ }^{71}$

1944. X. 5-én hajnalban a vasútrobbantás után az osztag öt embere a Bene községtől 15 km-re, északkeletre fekvő Salánkon megpróbált élelmiszert szerezni. A faluban állomásozó csendőrök azonnal rajtuk ütöttek. A kialakuló tüzharcban egy fő partizánt lelöttek, a többi a felszerelését eldobálva elmenekült. A csendőrök négy pokolgépet és egyéb robbanóanyagot gyüjtöttek be, ami arra vallott, hogy a csoport további robbantásos támadásokra készült. Ugyanezen a napon Fornos és Pisztraháza között (Munkács D $10 \mathrm{~km}$ ) az osztag egy másik különítménye megtámadott egy vágóállatokat örző honvéd szakaszt. A katonák azonban viszonozták a tüzet. Félve, hogy a honvédek erősítést kapnak, a partizánok rövid idő múlva visszavonultak. A harci tevékenység mellett az élelem utánpótlás biztosítása folyamatos feladatot jelentett, 1944. X. 5-én a USZTA szovjet ejtőernyös partizán osztag törzséhez tartozó partizánok Kislécfalván (Munkács ÉK $12 \mathrm{~km}$ ) rekviráltak élelmiszer. ${ }^{72}$

1944. X. 6-án a PUT parancsnoksága közölte rádión USZTA szovjet ejtőernyős partizán osztaggal, hogy a továbbiakban az irányításukat a 4. Ukrán Front Partizán Törzse veszi át. A Partizán Törzs parancsnoka 1944. X. 7-én felvette a kapcsolatot az osztaggal. Közölték, hogy a szovjet csapatok támadását közvetlenül segítő felderítési és diverziós tevékenységet várnak el. Elsősorban Munkács elöterében megvalósuló tevékenységet igényeltek. Ugyanakkor, újabb hadianyag utánpótlásra tettek ígéretet az új feladatok eredményes ellátása érdekében. ${ }^{73}$

1944. X. 6-án az osztag partizánjai Felsőremete (Ilosva NYDNY 15 km) községnél megtámadott egy kisebb honvéd alakulatot. A honvédek viszonozták a tüzet, a partizánok végül visszahúzódtak. Október elején az osztag megnövekedett erejében bízva többször intézett támadást kisebb katonai alakulatokk, illetve csendőr őrsök és járőrök ellen. A támadásokat rendszerint lesböl, a meglepetés erejét is felhasználva, váratlanul megnyitott heves tüzzel és nagyobb számú kézigránát alkalmazásával hajtották végre. Ha az ellenfél összezavarodott, akkor könnyen menekülésre tudták kényszeríteni. Ha viszont a megtámadott honvéd vagy csendőr alakulat felvette a harcot, kis idő múlva még a nyilvánvaló túlerőben lévő partizánok is visszavonultak az erdőbe. ${ }^{74}$

1944. X. 7-én hajnalban a partizánok lesállást foglaltak a Munkács-Huszt főútvonal mentén Nyíresújfalu (Munkács DK $20 \mathrm{~km}$ ) közelében. Magyar honvéd egyenruhába öltözött partizánok megállítottak egy személyautót, foglyul akarták ejteni a benne ülőket. Az autóban az 1. hadsereg híradó-zászlóaljának parancsnoka utazott, egy alezredes, főhadnagy segédtisztjével. Mivel nem adták meg maguk, hanem ellenálltak, a partizánok lelötték a két tisztet és a sofört. A kocsiban lévő dokumentumokat azonban nem tudták megszerezni, mert újabb gépkocsik közeledtek. Az eset nyomán, hogy a hasonló helyzeteket elkerüljék MIKLÓs Béla vezérezredes, az 1. hadsereg parancsnoka elrendelte, hogy tiszti gépjármüvet honvéd járörök csak lakott területen állíthatnak meg igazoltatás céljából. ${ }^{75}$ Ugyanezen a napon a Munkács-Szolyva vasútvonalon, Kishídvég község közelében a partizánok aláaknázták a síneket. Másnap 
délelőtt egy arra közlekedő tehervonat alatt felrobbant a töltet. A mozdony és két vasúti kocsi kisiklott és megrongálódott. Az osztag-parancsnok későbbi jelentésében erős túlzással öt vagon megsemmisüléséről számolt be, és jelentősebb katonai veszteségekről, ami nem felelt meg a valóságnak. ${ }^{76}$

1944. X. 8-án az osztag egyik 15-20 fös fegyveres különítménye megtámadta a Buzsorán lévő légvédelmi figyelő őrsöt. Az őrs hét fős személyzete kézigránátokkal keményen védekezett, mire a partizánok visszavonultak. Ezen a napon a partizánok betörtek Hátmeg község szélső házaiba és élelmiszert raboltak. 1944. X. 9-én az élelmiszer rekvirálást német és magyar egyenruhás partizánok Bábakúton, Medence községben (Ilosva NY $5 \mathrm{~km}$ ) folytatták. 1944. X. 9-én éjszaka az osztag légi úton hadianyagot kapott. Zajgó községtől 10 km-re, délre, a megjelölt helyen két zsák géppisztolytöltényt és 100 kézigránátot dobtak le számukra. ${ }^{77}$

1944. X. 10-én a partizánok a Munkács-Huszt fơút mentén, Beregkövesd térségében kilenc távíró és telefonpóznát robbantottak fel, egy időre megszakítva az összeköttetést a két város között. Ugyanekkor a Borló-hegység északi oldalán az osztag partizánjai aknákat telepítettek a Szolyva-Huszt útra. Az egyik szerkezet egy magyar katonai szekér (országos jármü) alatt robbant és megsebesítette a hajtót. Az eset nyomán kivonuló müszaki egység további kilenc aknát távolított el az útszakaszról. A nap folyamán a partizánok Huszt térségében, Husztbaranya községnél (Huszt KDK $5 \mathrm{~km}$ ) megtámadták a település szélén lesállásban lévő négy fős csendőr járőrt. A csendőrök élénk tüzeléssel verték vissza a támadást, két fö partizánt lelöttek, a többiek elmenekültek. ${ }^{78}$

1944. X. 15-én az USZTA szovjet ejtőernyős partizán osztag azt az utasítást kapta Sztanyiszlavból, hogy fokozza a támadásokat a múködési körzetében állomásozó vagy azon átvonuló magyar csapatok ellen, hogy ezzel is elősegítse a szovjet erők offenzíváját. A Vörös Hadsereg ekkorra Kárpátalja egy részét már birtokba vette és megközelítette a Borló-hegység délkeleti térségét. az üzenetvétel napján a partizánok Boród község közelében megtámadták a 4. hegyi zászlóalj Ilosváról Hátmeg felé tartó egyik menetoszlopát. A mintegy 35-40 partizán által rajtaütésszerüen, az út mindkét oldaláról megnyitott tűz, megadásra késztette a honvédeket. A partizánok három aknavetőt, több golyószórót és más fegyvereket zsákmányoltak. Az elfogott nagyobb létszámú honvédet (a partizán osztag parancsnokának állítása szerint 250, valójában 127 föt) később szabadon engedték, mert örzésük komolyabb eröket kötött volna le. ${ }^{79} 1944$. X. 16-án este újabb utánpótlást szállító repülőgép indult a partizán osztaghoz. A frontvonal felett azonban a repülőgép erős légvédelmi tüzet kapott, ezért visszafordult. Emiatt utasították a partizán osztagot, hogy keressen egy másik ledobási körzetet, a fronttól legalább 20-30 km távolságra, amit a gépek a légvédelem elkerülésével könnyebben meg tudnak közelíteni. Közben tovább nőtt az USZTA szovjet ejtőernyős partizán osztag létszáma. A németek által partizánvadászatra bevetett 40 fős vlaszovista alakulat, a tisztjével az élen csatlakozott a partizánokhoz. ${ }^{\mathbf{8 0}}$

A partizán osztag több vasúti diverziót hajtott végre, 1944. X. 16-án a munkácsi állomáson dolgozó beszervezett ruszin vasúti munkások segítségével az osztag egyik különítménye robbanóanyagot csempészett egy mozdony szerkocsijába, a szén közé. Nem sokkal a szerelvény indulása után a fütő belapátolta a trotilt a mozdonyba, ami a város szélén, a dohánygyár közelében felrobbant. A mozdonyvezető meghalt, a fütő megsebesült. 1944. X. 17-én éjszaka az osztag egy másik különítménye Rakasz falunál (Huszt NYÉNY 8 km) aláaknázta a Huszt-Beregszász vasútvonalat. Másnap 8 órakor robbant a szerkezet egy szerelvény alatt, amely kisiklott, egy mozdony és 17 vasúti kocsi megrongálódott. ${ }^{81} 1944$. X. 18-án a munkácsi állomáson a ruszin vasúti munkások segítségével mágneses aknát helyeztek el egy tartályvagonon. Az akna felrobbant, a tartálykocsi kiégett. A nap folyamán a partizán osztag különítménye aláaknázta a Munkács-Szolyva vasútvonalat. A telepített akna másnap 9 órakor robbant fel egy szerelvény alatt, egy mozdony és hat vasúti kocsi megrongálódott. A pályát délutánra helyreállították, de az este folyamán a partizánok egy másik helyen ismét aknát telepítettek. 1944. X. 20-án reggel egy újabb szerelvény, egy mozdony és öt vasúti kocsi rongálódott meg robbanás következtében. ${ }^{82}$

1944. X. 17-én a partizánok Kisábránka térségében négy-öt szekérből álló honvéd menet oszlopot fogtak el, nyolc fegyveres és 30 munkaszolgálatos honvéddel, amely nagyobb mennyiségü élelmiszert szállított. A szekereket felgyújtották, a foglyokat elengedték, az élelmet a táborukba szállították. Ettől a helytől hat km-re, nyugatra az osztag egy másik különítménye megtámadta „Kolozsvár” őrszázad Bábakúton állomásozó szakaszát. Az összecsapásban egy honvéd meghalt, egy eltűnt, három fö pedig megsebesült. A partizánok újabb támadást kíséreltek meg a térség rendjének fenntartásában kulcsszerepet játszó hátmegi csendőr örs ellen is. A csendöröket azonban nem sikerült meglepni. A nagy létszámú, automata fegyverekkel felszerelt partizáncsapat ellen az örs személyi állománya kézigránátokkal védekezett. A partizánok két halott és három sebesült veszteséggel kénytelenek voltak elvonulni. ${ }^{83}$

1944. X. 18-án az osztag egyik különítménye Oláhcsertész községben hajtott végre rajtaütést a 2. gyalogezred egyik pihenőben lévő leharcolt szakasza ellen. A partizánok megadásra szólították fel a 35 
honvédet. Parancsnokuk, egy zászlós hosszabb alkudozás után, a szabad elvonulás fejében beleegyezett a fegyverletételbe. A zsákmány egy golyószóró, 33 puska, két géppisztoly és 150 kézigránát, valamint 12000 töltény volt. A honvédek Hátmegre mentek, ahová időközben egy honvéd század érkezett. A partizántámadás hírére a századot Oláhcsertészre küldték a partizánok elfogására, azok időközben azonban már visszahúzódtak a 4-5 km-re északabbra fekvő Kisábránka térségébe. A honvédek visszatérésének hírére 50-60 partizán tört be újra Oláhcsertészre, további zsákmány reményében. Hosszabb tüzharc bontakozott ki, majd sötétedéskor a honvédszázad visszavonult. Az osztag parancsnoka egy szakasznyi partizánt hagyott a településen, és felfegyverezte a helyi lakosság egy részét is ${ }^{84}$

1944. X. 19-én mintegy 150 honvéd és 35 csendőr újabb próbálkozást tett a Borló-hegység keleti térségében fekvő falvak biztosítására. Kenézpatakot sikerült elfoglalniuk, Oláhcsertészt és Végmártonkát viszont megtartotta az USZTA szovjet ejtőernyős partizán osztag aknavetőkkel, géppuskákkal felszerelt mintegy 100 fönyi fegyverese. A honvédség és a csendőrség 37 halottat és sebesültet vesztett, a partizánok vesztesége 25 fő volt. A front ekkor már csak alig 10-15 km-re húzódott. A következő napon a frontról visszavonuló magyar menetzászlóalj alegységei próbáltak átvonulni Végmártonka-Kisábránka körzetén. A partizánok lesállásból, meglepetésszerüen nyitottak tüzet a honvédekre, az elöl haladókat hangtompítós puskákkal lötték le. Több órán át tartó heves harc bontakozott ki, melyben a partizán osztag megőrizte a pozícióit. A fronton elszenvedett súlyos veszteségek miatt részben már demoralizálódott zászlóalj honvédjeinek egy része szervezetten elvonult, de sokan fegyverüket hátrahagyva szétszéledtek. Magyar részről a veszteség 24 fö halott, 17 fő sebesült és 49 fő fogoly volt. A partizánok nyolc golyószórót, 10 géppisztolyt, 54 puskát, 400 töltényt, valamint 18 lovat és szekeret zsákmányoltak, miközben mintegy 30 fö halottat és sebesültet vesztettek. ${ }^{\mathbf{8 5}}$

1944. X. 20-án, a Munkács közelében, a várostól 15-20 km-re, keletre, a szaporodó partizánakciók megakadályozására a frontról visszavont ungvári csendőr tanzászlóalj 2. századának megerősített szakaszát (három golyószóróval, 10 géppisztollyal) csendőr föhadnagy vezetésével kirendelték Hátmegre. Kárpátalja katonai parancsnoka a Hátmegen összevont csendőr és honvéd erők (a „Kolozsvár” őrszázad és a 2. gyalogezred néhány alegysége) parancsnokának a kirendelt csendőr főhadnagyot nevezte ki, honvéd állomás-parancsnoki hatáskörrel. 1944. X. 21-én megérkezett az aknaszlatinai csendőr század is egy csendőr százados vezetésével. A csendőr főhadnagy elsődleges feladatnak a térség fő partizánbázisává váló Végmártonka megtisztítását tekintette. A csendőr alakulat viszonylag jól fel volt fegyverezve, 10 golyószórójuk mellett a legénység egy része a Rónahavason zsákmányolt dobtáras géppisztolyokkal is rendelkezett. ${ }^{\mathbf{8 6}}$

1944. X. 22-én egy század honvéd és egy század csendőr, három oldalról intézett támadást a Végmártonkát megszállva tartó partizánok ellen. Közben a partizánok felderítöi Hátmeg közelében jártak, a csendőr járőr azonban észrevette őket, a kialakult tüzharcban egy partizánt lelőttek. A csendőröknek és a honvédeknek több órás nehéz küzdelemben a falut sikerült visszafoglalni, a partizánok elmenekültek. Jelentősek voltak azonban a veszteségek is. Elesett hét fö csendőr és 14 fö honvéd, továbbá megsebesült 15 fő csendőr és 12 fő honvéd. Sebet kapott az akciót irányító honvéd és csendőr tiszt is. A partizánok 32 halottat és körülbelül ugyanannyi sebesültet vesztettek. A jól megtervezett és irányított fegyveres fellépés tehát meghátrálásra tudta késztetni a nagyobb partizánegységeket is. A történtek egyben jelezték, hogy ha a Kárpátalján tartózkodó csendőr erőket október első heteiben nem kellett volna a frontvonalban felhasználni, könnyebben ellenörzés alatt tarthatták volna a növekvő létszámú partizáncsoportokat is ${ }^{87} \mathrm{~A}$ szovjet csapatok gyors elörenyomulása miatt azonban az elért harcászati siker nem lehetett tartós. A Hátmegen összevont csendör erőket 1944. X. 23-án visszarendelték Ungvárra. Az ungvári csendőr tanzászlóalj 1. századát 1944. X. 23-tól Munkács, a 2. századot Ungvár védelmében vetették be. A Munkács védelmére irányított csendőri erők egyik szakasza 1944. X. 23. és 25. között Munkács északi előterében — a szovjet főerők megérkezéséig — partizán elhárítást folytatott. 1944. X. 30-án a zászlóaljat visszarendelték Budapest védelmére. ${ }^{88}$

1944. X. 25-én az osztag egyik különítményének 23 fegyverese Boród községnél az Ilosva-Munkács út mentén foglalt lesállást. Előttük haladt el a visszavonuló 4. honvéd hegyi zászlóalj egyik alegysége. A partizánok tüzet nyitottak. A honvédek kezdetben viszonozták a tüzet, de akkor a másik oldalon egy újabb partizánok jelentek meg, ami megtörte a honvédek ellenállását, az alakulat visszavonult, 25 honvéd fogságba esett. Partizánok három aknavetőt, egy golyószórót, 24 puskát és 12 lovat zsákmányoltak. Az osztag egy másik különítménye az éjszaka folyamán Boródtól nyugatra, 4 km-re egy átvonuló honvéd tüzéralakulaton ütött rajta. A kialakuló tüzharcban öt fö honvéd elesett, nyolc fö megsebesült, 13 fó honvédet pedig elfogtak a partizánok. A partizánok egy géppuskát, két golyószórót, 14 puskát zsákmányoltak. A harcban négy partizán is megsebesült. Ekkorra a partizán osztag a Munkács-Huszt fóút és a Borló-hegység közötti területet teljesen az ellenörzése alá vonta. A szovjet csapatok 1944. X. 26-án érték el ezt a térséget. ${ }^{89}$ 
1944. X. 26-án az USZTA szovjet ejtőernyős partizán osztag 168 fő volt, ezen belül 59 fö orosz (szovjet), 84 fö ukrán, ruszin, 25 fő magyar. A helyi magyar lakosságból alig 10-15 fö csatlakozott a partizánokhoz, a civil jelentkezők főleg ruszinok voltak, de a harcos létszám emelkedését a szökött hadifoglyok, illetve más, szétvert partizáncsoportok tagjainak összegyüjtése eredményezte. Az osztag fegyverzetét három aknavető, három géppuska, 17 golyószóró, 84 géppisztoly (más források szerint: 15 golyószóró és 40 géppisztoly), 189 puska, 19 pisztoly, 325 kézigránát, 5000 géppisztoly és 12000 puskatöltény képezte. Ez az arzenál messze felülmúlta a terület közbiztonságáért felelős csendőrség fegyverzetét, de a térségben elhelyezett különböző katonai őrségek tüzerejét is. ${ }^{90}$ Az osztag parancsnoka múködéséről készített jelentésében 21 fö halott (más források szerint 33 fö) és 12 fö sebesült saját veszteséget említett, ebben a számban azonban csak az ejtőernyővel ledobott partizánok szerepelnek, az osztaghoz menetközben csatlakozó közel 200 fö veszteségei nem. Az egység harci teljesítménye hétmozdony és 79 vasúti kocsi megsemmisítése, megrongálása egy vasúti híd felrobbantása, két teherés egy személyautó felgyújtása volt, miközben 40 lovat, nyolc szekeret, egy személyautót és egy motorkerékpárt zsákmányolt. Harc közben a német-magyar erőknek 1064 fös személyi veszteséget okoztak (365 fö halott, 412 fö sebesült, 267 fő hadifogoly) Ezek az adatok azonban bizonyos mértékig eltúlzottak. Ezzel együtt a magyar területen müködő partizán osztagok közül az USZTA szovjet ejtőernyős partizán osztag volt az egyik legsikeresebb. ${ }^{91}$

A Kárpátalján tevékenykedő másik jelentős partizán erő a 13 fős TKANKO szovjet ejtőernyős osztag volt, akiket 1944. VII. 21-én dobták le ejtőernyővel a Róna-havas északnyugati körzetében. Az osztag parancsnoka alezredesi rangban volt, így ö volt a legmagasabb rendfokozatú tiszt a kárpátaljai magyar területeken bevetett partizán osztagok vezetői között. ${ }^{92}$ Az osztagot a későbbiekben felállítandó nagyobb létszámú partizán erő törzsének szánták. Az osztag elsődleges feladata ennek megfelelően a szervezés, a helyi ukrán lakosság körében végzett agitáció, toborzás, illetve egyéb harcra fogható személyek, szétszórt partizáncsoportok tagjai, szökött hadifoglyok, katonaszökevények összegyüjtése volt. Az így létrehozandó nagyobb alakulattól a PUT azt várta, hogy nagyobb jelentőségű akciókat hajtson végre. A leszállás során, illetve az azt követö összecsapásban a csoport több tagja meghalt, illetve megsebesült, négy fö pedig elszakadt a többiektől, és csak egy hónappal később sikerült újra találkozniuk. Az osztagparancsnok szervezőmunkája és további fegyveres összecsapások elől kitérỏ taktikája nyomán a csoport fokozatosan erősödött, július végére 40-50 fő fegyveressel rendelkezett. ${ }^{93}$ Augusztus utolsó harmadában a PUT sürgetésére a megnövekvő létszámú osztag már akciókra is elszánta magát. Támadásokat intézett hadifogolytranszportok, kisebb katonai őrségek, légvédelmi figyelő őrsök ellen. 1944. VIII. 24-én 50 fö partizán lerohant egy, a hegyekben lévő katonai tábort. A 21 főnyi, főként póttartalékosokból álló őrség rövid harc után (3 fö halott, 14 fö sebesült) megadta magát, a partizánok feldúlták a tábort, a használható felszerelést magukkal vitték. ${ }^{94}$

A magyar hatóságok 1944. VIII. 31-én nagyszabású tisztogató müveletet indítottak, hogy a Rónahavas térségében müködő partizán osztagokat felszámolják. Jelentős honvédségi erők, a 23. gyaloghadosztály részei és határvadász egységek, valamint az aknaszlatinai csendőr század, az ungvári, munkácsi és nagybereznai csendőr szárnyak állományából összeállított szakaszok, illetve a térségben lévő csendőr őrsök legénysége, az ejtőernyős-elhárító szolgálat és a helyi polgári karhatalom igénybevételével, átfésülték a Róna-havas déli körzeteit. A jól szervezett, nagy erökkel végrehajtott akció során mintegy 50 fö partizánt megöltek, 130 főt pedig elfogtak, és jelentős mennyiségü hadianyagot, fegyvert, löszert zsákmányoltak. Ezzel a hegység déli területein egy időre sikerült helyreállítani a rendet és a közbiztonságot. ${ }^{95}$

A tisztogató akció idején a TKANKO szovjet ejtöernyős partizán osztag a Róna-havas északi körzetében tartózkodott, komolyabb veszteséget nem szenvedett. A hadmüvelet befejezése után az osztag azonnal hozzálátott, hogy a szétvert csoportok maradványait összegyüjtse, ezzel is erősítve saját osztagát. Az osztag felderítői folyamatosan cirkáltak a központi bázistól távolabb (egy-három napi járásra) eső területeken is, megkeresték és a táborukba vitték a hegyek közt kóborló, partizánokat, szökevényeket. Augusztus végére az osztag már 150 főből állt, fegyvert azonban egyelöre csak 85 főnek tudtak adni. A PUT is felismerte, hogy ebben a térségben a TKANKO szovjet ejtőernyös partizán osztag a legütőképesebb erö, amely viszonylag biztonságos bázist tudott kiépíteni. Ezért a későbbiekben bevetésre kerülő partizán osztagokat rendre a TKANKO szovjet ejtöernyős partizán osztag müködési területén dobták le, hogy a földet érés után pihenni tudjanak és nyugodtabb körülmények között készülhessenek fel a feladataik végrehajtására. Jelentős mennyiségü hadianyagot is szállítottak az osztag részére részben saját céljaira, részben az általa fogadott többi osztag készleteinek kiegészítésére. ${ }^{96}$

1944. VIII. 28-án egy új, a 11 fös VANYAGIN szovjet ejtőernyös partizán osztagot dobtak le Kárpátalján, akik Berezna térségében ért földet (Huszttól ÉK $25 \mathrm{~km}$ ). ${ }^{97}$ A leszállásnál az osztag-parancsnok és egy embere megsérült. Az ejtőernyősök érkezéséről a hatóságok azonnal értesültek. Felkutatásukra 
kivonult a lipcsei, az alsóbisztrai és a kövesligeti csendőr őrs személyi állománya. Erősítéskre Husztról két szakasz honvédet és egy szakasz csendőrt vezényeltek ki. Az osztag tagjai közül két főt néhány órán belül elfogták, és magyar kézre került a rádió adóvevő is. A két partizánt előbb Husztra, a szárny-parancsnokságra, majd Ungvárra szállították a 8/1. csendőr-nyomozó alosztályra, kihallgatásra, ezt követően Budapestre kerültek. Mindkettőjüket halálra ítélték, a nő esetében azonban az ítéletet életfogytiglanra enyhítették. A partizán nőnek később sikerült megszöknie. A többieket helyi ruszin lakosok segítették, hogy kijussanak a köréjük vont gyürüből. Az osztag nem tudott semmilyen akciót végrehajtani, folyamatosan bujkálva északkeleti irányban, a magasabb hegységek felé menekült. Az üldözőkkel folytatott összecsapásokban négy fö elesett. Az osztag maradéka szeptember közepén elhagyta a Magyarország területét. ${ }^{98}$

Nem volt sokkal sikeresebb az ugyancsak 1944. VIII. 28 -án Ilosva közelében ledobott hét fôs $\underline{P E T-}$ RENKO szovjet ejtöernyös partizán osztag sem. A néhány nappal korábban leszállt PRISCSEPA szovjet ejtöernyős partizán osztag miatt a térségben a honvédség és a csendőrség sürü járőrözést folytatott, így a földet érő ejtőernyősök szinte azonnal fegyveres összecsapásba keveredtek. Két partizánt nem sokkal a megérkezésük után tủzharcban lelőttek, két főt pedig elfogott az ilosvai csendőr őrs járőre. A megmaradt 3 partizánnak később sikerült feljutni a Borló-hegységbe és csatlakoztak USZTA szovjet ejtöernyös partizán osztaghoz.99

1944 szeptemberétől a Kárpátalja területén müködő partizán osztagok tevékenysége már közvetlen kapcsolatba került a fronton zajló eseményekkel. 1944. IX. 9-én indult a Kárpátok-Ungvár hadművelet, melynek keretében a 4. Ukrán Front 18. hadserege az Uzsoki-, Vereckei és a Toronyi-hágón át, a 17. hadest pedig a Tatár-hágón keresztül nyomult be Kárpátaljára. A Vörös Hadsereg erői 1944. IX. 30-ra megvetették lábuk a Keleti-Kárpátok fő hegyvonulatán. Eközben a 2. Ukrán Front csapatai Észak-Erdély jelentős részét már elfoglalták, és a front jobbszárnya szeptember végére Máramarossziget térségéig jutott. 1944. X. 7-én a 4. Ukrán Front csapatai átkeltek a Vereckei-, 1944. X. 16-án pedig az Uzsoki hágón. 1944. X. 23-án elesett Huszt, 1944. X. 25-én Munkács, 1944. X. 26-án pedig Ungvár. Két nappal később már egész Kárpátalja gyakorlatilag szovjet kézen volt. A harcok hevességét jelezte, hogy a szovjet csapatok a Kárpátok-Ungvár hadmüvelet során 53253 fös veszteséget szenvedtek (11 866 fő halott és eltüntszemély, valamint 41387 fö sebesült), a német és magyar csapatok pedig Kárpátalja védelmében mintegy 40000 föt veszítettek (18 000 fö halott és eltünt személy, valamint 22000 fő sebesült). ${ }^{\mathbf{1 0 0}}$

Az 1944 szeptember eleji szovjet offenzíva támogatása, újabb felderítési adatok küldése, a hadiszállítás akadályozása és a lakosság hétköznapi életének megzavarása érdekében különböző szovjet szervezetek, a PUT, a Vörös Hadsereg föparancsnoksága, illetve a támadó 4. Ukrán Front vezetése újabb partizán osztagokat dobott le Kárpátalján, köztük a 24 fös BOLOTNYIKOV szovjet ejtöernyös partizán osztagot. ${ }^{101} \mathrm{Az}$ osztagot Bereznek térségében (Szolyva $\mathrm{K} 15 \mathrm{~km}$ ) tervezték ledobni, és feladata a Szolyva-Verecke foút, illetve a Szolyva-Vóloc vasútvonal mentén való felderító és diverziós tevékenység volt. A 2 szállítógép azonban túlrepült a célterületen, és attól 20 km-re, délnyugatra, Kenézpatak közelében dobta le az ejtőernyősöket. A második gépen utazó 10 fö két részletben ugrott, közben kidobták a kiegészítő felszerelést tartalmazó ejtőernyős zsákokat. Az utolsóként kiugró öt fő nyugat felé elsodródott, és a többiektől hat-nyolc km-re Bábakúttól délre ért földet. ${ }^{102}$

A leszállás után a többségükben német egyenruhába öltözött partizánok észak felé indultak a Borlóhegységen át. Végmártonka község határában elfogtak egy erdőőrt, akitől a Szolyva felé vezető legbiztonságosabb útvonal felöl érdeklődtek. Ezzel egyidőben Bábakút mellett is láttak öt, német egyenruhás partizánt északi irányba elvonulni. A partizánok továbbhaladása után a kikérdezett erdőőr bejelentést tett a hátmegi csendőr örsön. Az örs egy megerösített járöre (négy csendőr) azonnal a partizánok után indult, és közben riasztották a munkácsi és a szolyvai örsöket is. A hátmegi csendőrök hajnalban, Végmártonkától északra elfogtak két fegyvertelen férfit, akik elöször ukrán menekülteknek mondták magukat, hamarosan kiderült azonban, hogy az egységüktől leszakadó partizánok voltak. ${ }^{\mathbf{1 0 3}}$ 1944. IX. 8-án Vocsitelep (Szolyva ÉK $12 \mathrm{~km}$ ) vasútállomása mellett hat-hét partizán vonult el, akik lövéseket adtak le az állomásépületből kilépő váltóőrre. A váltooőr azonnal jelentette az esetet Szolyvára. A szolyvai csendőrök és a helyi honvéd karhatalom hamarosan az ejtőernyősök nyomára akadt. Tüzharc bontakozott ki, két fö partizán meghalt, a többi fogságba esett. Az összecsapás során két fö honvéd is könnyebben megsebesült. ${ }^{104}$

1944. IX. 7-én éjszaka a Róna-havas fölé is berepült több szovjet szállítógép. Két PSZ-47 szállította a 22 fös RUSZIN szovjet ejtöernyös partizán osztagot, akik a TKANKO szovjet ejtöernyös partizán osztag által ellenőrzött területén értek földet a biztonságosabb érkezés céljából. Egy harmadik gép pedig nagyobb mennyiségủ légi utánpótlást, robbanóanyagot, fegyvert és lőszert, egészségügyi felszerelést és élelmiszert dobott le a TKANKO szovjet ejtőernyős partizán osztag számára. A RUSZIN szovjet ejtőernyös 
partizán osztag tagjait szállító egyik gépen a parancsnokkal együtt 11 partizán utazott, két nagy ejtőernyős zsákkal, amelyek tartaléklőszert, élelmet, és robbanóanyagot tartalmaztak. ${ }^{105} \mathrm{Az}$ osztag első része viszonylag szerencsésen földet ért, csak egy fő szenvedett komolyabb sérüléseket a leszállásnál. A rádiós messzire sodródott, fennakadt egy fán, amikor levágta magát az ejtőernyőről, leesett és kificamította a lábát, a többiek azonban néhány órán belül megtalálták. Az ejtőernyős zsákok viszont elsodródtak, az egyikben a csoport rádiókészülékével, amit több napos keresés után sem találtak meg. ${ }^{106}$

Az osztag másik felét szállító gép a frontvonal felett komolyabb légvédelmi tűzbe került és eltért az útvonalától. A célterület fölé érkezve nem találta meg a TKANKO szovjet ejtőernyös partizán osztag által gyújtott jelzőtüzeket, ezért az ejtőernyősökkel együtt visszatért Kijevbe. 1944. IX. 11-én újra megpróbálták ledobni őket, a Kárpátok felett uralkodó rossz időjárás miatt azonban a gépnek korán vissza kellett fordulnia. Végül 1944. IX. 13-án dobták le a RUSZIN szovjet ejtőernyős partizán osztag maradék 11 tagját a Róna-havas északi körzetében. ${ }^{107}$ A leszállás során a politikai helyettes súlyosan megsérült, és további két fő nem tudott lábra állni. 1944. IX. 14-én RUSZIN szovjet ejtőernyős partizán osztag tagjai bevonultak TKANKO szovjet ejtöernyös partizán osztag táborába, ahol három napot töltöttek., hogy kipihenjék a földet érés viszontagságait. Ekkor tájékozódtak a helyi viszonyokról és felkészültek a kijelölt feladatuk végrehajtására, majd a sérülteket hátrahagyva, 1944. IX. 17-én útnak indultak déli irányba, Szolyva környékére. 1944. IX. 21-én Beregforrás és Turjamező között alakították ki táborhelyüket. A nap folyamán kilenc partizán a közeli Szarvaskút községben (Beregforrás D $5 \mathrm{~km}$ ) élelmiszert rekvirált.. ${ }^{108}$

RUSZIN szovjet ejtőernyős partizán osztag az első támadását 1944. IX. 22-én hajtotta végre, a Perecseny-Polena müúton, Szarvaskút térségében lesből tüz alá vettek két tüzérségi löszert és élelmiszert szállító teherautót. A támadásban 3 német katona meghalt, a többi kísérő elmenekült. A partizánok az élelmiszer egy részét magukkal vitték, a 2 gépkocsit felgyújtották. A polenai és a poroskői csendőr őrs személyi állományát, az ejtőernyős-elhárító szolgálat egyik alakulatával és a szarvaskúti német katonai raktár őrségének egy részével kivezényelték a partizánok felkutatására a müúttól északra lévő területen. $\mathrm{A} z$ osztag azonban ekkorra már az úttól délre, Pataktanya mellett (Kispálos NY 2 km) táboroztak. Kihasználva a szarvaskúti raktár örségének kivonulását, 1944. IX. 23-án este megtámadták a bázist. Hangtompítós puskával lelöttek három őrt, majd betörtek a raktárba. A kialakuló tűzharcban további hat német katona elesett. A partizánoknak két fő veszteségük volt. A támadás után a csoport déli irányban haladt tovább, és 1944. IX. 26-án Bányfalu (Szolyva NY 6 km) közelében létesített tábort. ${ }^{109}$

1944. IX. 30-án Beregszentmiklóstól 1 km-re a RUSZIN szovjet ejtőernyős partizán osztag aláaknázta a Munkács-Szolyva vasút pályáját. A szerkezet a 415.sz. motorkocsi alatt robbant. A jármü megrongálódott, a rajta tartózkodók közül 13 fő megsérült, a forgalom azonban csak öt órán át szünetelt. A csoport folyamatos felderítést végzett a Munkácsról Verecke, illetve Uzsok irányába vezető foútvonal mentén, és jelentette Kijevbe a megfigyelt csapatmozgásokat. Időközben több ruszin lakos, illetve szökött orosz hadifogoly csatlakozott az osztaghoz. Nagyobb akciókra a csoport azonban nem vállalkozott. Tervezték ugyan a szolyvai löporüzem elleni támadást, vagy a Kishídvég vasútállomáson veszteglö üzemanyag szállító szerelvény (27 tartálykocsi) felrobbantását, de az erős katonai őrség miatt ezeket nem kockáztatták meg. ${ }^{110}$ A fokozódó partizán akativitás miatt 1944. X. 1-jén Szolyva térségében nagyobb csendőri és katonai erők összevonásával tisztogató akció indult a partizánok ellen, melyben Újtövisfalváról (Szolyva NY 4 km) 300 honvéd gyalogos, Kishídvégröl (Szolyva NY 8 km) 150 honvéd hegyivadász vett részt. A kutatócsapatok kutyákkal próbáltak a partizánok nyomára jutni. Az osztag 10 km-rel délebbre húzódott és Kislécfalva-Bábakút térségében létesített tábort. Útközben, helyi szimpatizánsok, köztük a szentmiklósi ruszin állomásfőnök segítségével egy veszteglö katonai szerelvényből hadianyagot, közte több száz kézigránátot szereztek. Átkelve a Latorica folyón, Repede falunál rajtaütöttek a 6. gyaloghadosztály nyolc katonáján, akik két szekérrel élelmiszert szállítottak. A kísérők közül három föt lelöttek, egy főt elfogtak, a többiek elmenekültek. ${ }^{111}$

1944. X. 11-én értesítették RUSZIN szovjet ejtőernyős partizán osztagot rádión értesítették arról, hogy a felsőbb irányításukat a PUT átadta a 4. Ukrán Front Partizán Törzsének. Mivel a szovjet csapatok ekkor már Volóc közelébe értek, a központ — a többi kárpátaljai partizán osztaggal együtt — aktívabb diverziós tevékenységre utasította a RUSZIN szovjet ejtöernyös partizán osztagot is. 1944. X. 12-én este a RUSZIN szovjet ejtőernyős partizán osztag Beregvár és Kishídvég között aláaknázta a vasúti pályát. Az aláaknázott szakaszon áthaladó első szerelvény alatt a vasúti pálya fölrobbant, melynek következtében a szerelvényt húzó mozdonya és hat vagon kisiklott. A vasútvonal kijavítása egy napig tartott. Az osztag a csatlakozókkal együtt 1944 október közepére 139 före nőtt. Több 25-30 fös akciócsoportot (az osztagon belüli ,hadrendi” elnevezésük szakasz volt) állítottak fel, melyek saját felderítőkkel, robbantókkal, egészségügyi és élelmezési felelősökkel rendelkeztek, és a központi tábortól eltávolodva egyénileg hajtottak végre különböző feladatokat. Így egyszerre több ponton tudtak zavart kelteni, és ez megnehezítette az elhárító erők 
hatékony fellépését is. 1944. X. 20-án éjszaka a partizánok összevont támadást indítottak a Bábakúton állomásozó magyar őrszázad ellen. A többnyire idősebb korosztályú, tartalékos legénységen váratlanul ütöttek rajta, elfogtak egy tisztet és 25 honvédet, míg a többiek szétszéledtek. A partizánok két golyószórót, öt géppisztolyt, 28 puskát, 130 kézigránátot és 6000 töltényt zsákmányoltak.12

A sikeren felbuzdulva és a Vörös Hadsereg közeledését kihasználva, 1944. X. 23-án este támadást indítottak a Rjapigy községbe beszállásolt honvéd alakulat ellen. A mintegy 100 partizán által automata fegyverek és nagyszámú kézigránáttal végrehajtott váratlan támadást gyorsan megtörte a leharcolt és az arcvonalból kivont csapat ellenállását. Az összecsapásban 16 fő honvéd esett el, 310 fő pedig megadta magát. A partizánok egy géppuskát, hat golyószórót, 38 géppisztolyt, 402 puskát, 800 kézigránátot és 20000 töltényt zsákmányoltak. Az osztag utolsó nagyobb akciójára 1944. X. 24-én került sor, amikor ismét visszatérve a Latorica jobbpartjára Szentmiklós közelében egy visszavonuló honvéd századdal csaptak össze. A túlerőben lévő, jól felfegyverzett partizáncsoporttal folytatott tüzharcban 40 honvédelesett vagy megsebesült, 20 fő pedig fogságba került. A partizánok 25 fő́t vesztettek. Másnap a Vörös Hadsereg elérte Szolyva térségét. Az osztag müködésének 50 napja alatt kisiklatott egy vasúti szerelvényt, felégetett két katonai raktárt, két aknavetőt, két géppuskát és 10 golyószórót, 44 géppisztolyt, 461 puskát, 34000 töltényt, 1420 kézigránátot zsákmányolt, 251 fös veszteséget okozott a magyar és német haderönek és 346 foglyot ejtett. ${ }^{113}$

A RUSZIN szovjet ejtöernyös partizán osztagnak is támogatást nyújtó TKANKO szovjet ejtöernyös partizán osztag parancsnoka 1944 szeptember elejére az osztagát már több akciócsoportra osztotta. Ezeket az akciócsoportokat az osztagon belül századnak nevezték. Embereiből négy akciócsoportot állított fel, melyet 1944 október végére hatra növelt. Az akciócsoportok törzseit a ledobott ejtőernyősök alkották, személyi állományukat a később csatlakozó helyi lakosokkal, szökött katonákkal és hadifoglyokkal töltötték fel. A TKANKO szovjet ejtőernyös partizán osztag parancsnoka több akciócsoportot különbözö távolabbi térségekbe indított útnak, hogy önálló feladatokat lássanak el. A központi tábortól 40-50 km távolságra tevékenykedő akciócsoportok Uzsoktól Husztig számos helyen zavart tudtak kelteni, ugyanakkor megosztották a partizánok ellen bevethető rendvédelmi és honvédségi erőket. Az egyik ilyen akciócsoport 1944 szeptember elején az Uzsoki hágó előterébe, Fenyvesvölgy-Viharos-Tyiha térségébe vonult. A másik akciócsoport Huszt térségébe indult. ${ }^{114}$

1944. IX. 10-én TKANKO szovjet ejtőernyős partizán osztag parancsnoka értesült róla, hogy újabb tisztogató akció készül ellenük. A Róna-havas körüli stratégiai pontokon német és magyar csapatokat, valamint az ungvári, a munkácsi és a nagybereznai csendőr szárnytól érkező csendőr szakaszokat helyeztek el. 1944. IX. 13-án várták azonban RUSZIN szovjet ejtöernyős partizán osztag második részlegének érkezését, ezért a TKANKO szovjet ejtőernyös partizán osztag egyelöre nem vonult át más térségbe, hanem az ejtőernyősök leszállásának biztosítása érdekében, elterelő akciókba kezdtek. Emberei négy különböző körzetben hajtottak végre kisebb támadásokat, hogy a honvédségi és rendvédelmi erők figyelmét megosszák. Két robbantásra került sor a keskenynyomtávú vasútvonalon Kisberezna és Mércse között. A partizánok az Ungvár-Munkács föútvonalon egy honvéd teherautó oszlopra nyitottak tüzet Szerednye közelében. Mivel a támadások egymástól 30-40 km távolságra történtek, az adott terület átfésülése napokra lekötötte a csendőrség és a honvéd karhatalom eröit. Így 1944. IX . 13-án fogadni tudták RUSZIN szovjet ejtőernyős partizán osztag másik részét. 1944. IX. 17-én, amikor a RUSZIN szovjet ejtöernyös partizán osztag útnak indult a TKANKO szovjet ejtőernyős partizán osztag bázisáról a saját müködési körzetébe, a a TKANKO szovjet ejtőernyös partizán osztag emberei is elhagyták a régi táborhelyet, és Mokra térségében (Turjavágás ÉK $5 \mathrm{~km}$ ) telepedtek meg. ${ }^{115}$

1944. IX. 13-án - kihasználva a repülésre alkalmas időjárást — szovjet részről több ejtőernyős osztag is bevetésre került Kárpátalján. PSZ-47 kétmotoros szállítógép Beregszász körzetében, a várostól délnyugatra dobott le öt fö felderítő feladatot ellátó ejtőernyőst. A visszaúton, Dercen térségében (Munkács D 15-20 km) a repülőgép ismeretlen okból lezuhant. A személyzetéből egy fő meghalt, két föt pedig elfogott az alsókerepeci csendőr örs járöre. ${ }^{116}$

1944. IX. 18-án jelentős honvéd és csendőr erők kezdték meg a Róna-havas északi körzeteinek átvizsgálását, hogy felszámolják a TKANKO szovjet ejtőernyös partizán osztag bázisát. A Perecsnyböl érkező egységek Turjaremetétől északi irányban, Nagyturjaszög-Hárs-Kurucvár-Rónafüred felé nyomultak elöre. Másik oszlopuk Poroskőtől indulva Turjamezö-Mezőhuta térségét kutatta át, miközben a partizán osztag törzse éppen a két útvonal között rejtőzött. Északon, a Nagybereznáról induló csapatok egyik oszlopa Viharos-Fenyvesvölgy-Havasköz térségébe vonult, a másik Sóhát-Ungbükkös érintésével déli irányba, Rónafüred felé igyekezett. A szolyvai alakulatok kelet felöl, Polenán át Dombostelek-Szarvaskút-Beregforrás térségét szállták meg. Egy további alakulat a Róna-havas északkeleti oldala, Szarvasháza-Hidegrét körzetében biztosított. Vagyis a honvéd és csendőr egységek négy oldalról behatoltak a Róna-havas északi 
körzetébe és a hegyi falvakat útba ejtve igyekeztek bekeríteni az osztagot. A partizánok azonban a helyi ruszin lakosoktól tájékozódva kitértek a kereső egységek elől, és a hátukba kerülve kisebb rajtaütéseket hajtottak végre egy-egy alegységük ellen. A mozgósított, mintegy 700 katona és 100 csendőr, az ejtőernyős elhárító szolgálat 200 - 300 emberével kiegészítve sem volt elegendő a mintegy 100 km-es hegyes, erdős terület átfésülésére. Ennyi erővel csak a lakott településeket lehetett ellenőrizni és a nagyobb hegyi utakat lezárni. Az akció 1944. IX. 21-én komolyabb eredmény nélkül zárult. ${ }^{117}$

A kereső alakulatok megérkezésekor a TKANKO szovjet ejtöernyős partizán osztag meglapult. A Mokrától északra lévő központi tábor körül körkörös védelmet épített ki. A parancsnoki központot (törzs, hírközpont, ellátó részleg, fegyvermühely, propagandarészleg) két akciócsoport biztosította. Másik három akciócsoport pedig körkörösen, mintegy 8-10 km távolságban helyezkedett el. Az egyik akciócsoport Szarvaskút és Turjasebes között, egy másik pedig a Róna-havas déli részén Turjaremete és Antalóc között, egy harmadik pedig Kisturjaszög közelében rendezkedett be, és épített ki állásokat. Az akciócsoportok létszáma 1944 szeptemberében megközelítette, októberben pedig már meghaladta a 100 föt. A TKANKO szovjet ejtőernyős partizán osztag széles informátorhálózatot szervezett, hogy a hatóságok, a honvédség és csendőrség minden intézkedéséről időben értesüljön. Amikor 1944 októberben a hadi helyzet alakulása és az erők összevonása miatt a magyar honvédség és a rendvédelmi alakulatok kivonultak egy-egy községböl, az osztag parancsnoka azonnal odaküldött egy akciócsopotot, hogy ellenörzés alá vonja a település környékét. ${ }^{118}$

A partizánok számára komoly gondot okozott az élelmiszerellátás. Ha nem kaptak a környező falvak lakóitól, akkor betértek olyan községekbe, ahol nem volt csendőrség vagy honvéd alakulat és fegyverrel követeltek élelmet. A partizánok kisebb csoportokban lejártak a Róna-havas déli részére, ahol élelmet szedtek össze, majd visszatértek a 30-40 km-rel északabbra lévő bázisra. A helyi csendőr vagy honvéd járőrök ilyen távolságra nem követték öket, nagyobb kereső akciót pedig néhány gazda vagy vegyesbolt kirablása miatt 1944 őszén a hatóságok már nem indítottak. 1944. IX. 13-án Gombás (Munkács É $15 \mathrm{~km}$ ) község egyik boltjában jelent meg egy partizán és ételt és italt követelt, majd eltávozott. 1944. IX. 17-én Szerencsfalva (Munkács É $18 \mathrm{~km}$ ) határában, a terület ellenörzése közben egy megerösített csendőr járör nagyobb létszámú partizáncsoportba ütközött. A csendőrök felvették a harcot, és közben Munkácsról erősítést kértek. A tüzharc során a 8/1. ungvári nyomozó alosztály állományába tartozó csendőr életét vesztette. Ugyanezen a napon a Rónahavas északi részén, Havasköz községben 20 fó partizán hét lovat rabolt el a helyi lakosoktól. ${ }^{119}$

1944. IX. 20-án TKANKO szovjet ejtőernyös partizán osztag emberei Szarvasrét község (Poroskő D $5 \mathrm{~km}$ ) határában kifosztották egy erdőőr házát. A Poroskőről segítségére siető honvéd járőr tűzharcot vívott a támadókkal. Egy partizánt lelőttek. 1944. IX. 24-én a Szarvasréttől 10 km-re, délnyugatra fekvő Patakos községben jelent meg egy kisebb partizán csoport, élelmet, meleg ruhát és dohányt raboltak. A következő rekvirálási kísérlet azonban nem sikerült. 1944. IX. 26-án fegyveres polgárőrök vették fel a harcot az élelemért érkező partizánokkal. Egy fő partizánt lelőttek, egy fő polgárőr megsebesült, a partizánok ezúttal üres kézzel távoztak. ${ }^{\mathbf{2 0}}$

1944. IX. 20-án szállt le a 19 fös HOMENKO szovjet ejtőernyös partizán osztag a TKANKO szovjet ejtöernyős partizán osztag által ellenőrzött területen. Miután kipihenték magukat, feltöltötték a készleteiket és részletesen tájékozódtak a térségében fennálló helyzetröl, a TKANKO szovjet ejtőernyös partizán osztag felderítői kíséretében útnak indultak északnyugat irányban, mert kijelölt feladatuk szerint a magyarszlovák határ területén Nagyberezna-Takcsány, részben szlovák területen kellett tevékenykedniük. ${ }^{\mathbf{1 2 1}}$

1944. IX. 25-re a szovjet csapatok átkeltek a Kárpátok fó gerincén és elérték az Uzsok-HajasdCsontos-Révhely (Nagyberezna É $5 \mathrm{~km}$ ) vonalat. A 30. lövészhadtest elfoglalta az Orosz-hágót, 1944. IX. 30-án pedig a 17. lövészhadtest birtokba vette a Tatár-hágót. A TKANKO szovjet ejtőernyős partizán osztag ekkor már 415 fö́t számlált, és összesen hat, egyenként 50-60 fős akciócsoporttal rendelkezett. Az egyik akciócsoport az Ungvár-Perecseny föútvonal mentén portyázott. Kapuszög település mellett átkeltek az Ung folyón és lesben álltak az országút mentén, majd tüzet nyitottak egy nagyobb teherautó oszlopra, amely a frontra szállított utánpótlást. A támadás után északnak indultak, megkerülték perecsenyt, és Bercsényifalvától északra visszatértek az Ung bal partjára és délkelet felé, Turjaremete irányában haladtak. Nem számítottak ellenségre, de amikor Újszemere község magasságában átgázoltak a Turja folyón, a Perecseny-Szolyva úton akartak átkelni, belefutottak a perecsényi csendőr őrs megerösített járőrébe. A csendőrök tüzet nyitottak a partizánokra. Egy fö partizán meghalt, a többiek visszamenekültek az erdőbe. ${ }^{\mathbf{1 2 2}}$

Kismogyorósról (Munkács ÉÉNY $15 \mathrm{~km}$ ) a honvédség élelmezésére magyar honvédek el akartak hajtani egy gulyát. A partizánokkal szimpatizáló ruszin származású bíró értesítette erről TKANKO szovjet ejtőernyős partizán osztagot. A partizánok csapdát állítottak, amikor a 22 magyar honvéd megérkezett a 
településre, heves tüzeléssel fogadták őket. A honvédek nem számítottak fegyveres ellenállásra, ezért harc nélkül visszavonultak. A Kismogyoróstól két km-re, északra fekvő Rosztovatovci településen a partizánok megölték egy erdészt, mert tájékoztatni akarta a csendőröket, hogy merre van a partizánok bázisa. ${ }^{123}$

A partizánharc más körzetekben is megélénkült. 1944. X. 5-én TKANKO szovjet ejtőernyös partizán osztag egyik akciócsoportja Dombó mellett (Máramarossziget É $25 \mathrm{~km}$ ) rajtaütött a 10/8. számú légvédelmi figyelő őrsön. A hét honvédet lefegyverezték, az őrs-parancsnok szakaszvezetőt és egy honvédet elhurcoltak. A partizánok 1944. X. 9-én Irhóc-Lázi település mellett egy erdei úton vonuló magyar szekéroszlopot támadtak meg. A honvéd század felvette a harcot, az összecsapásnak azonban gyorsan véget vetett egy német gépesített egység közeledése, amit észlelve a partizánok eltűntek az erdőben. A partizánok sikeresebb akciója volt, amikor az egyik akciócsoportjuk 1944. X. 11-én Úrmező közelében (Técső NYÉNY $7 \mathrm{~km}$ ) robbantást hajtott végre a Huszt-Máramarossziget vasútvonalon, melynek során egy mozdony, hat vasúti kocsi kisiklott és megrongálódott. ${ }^{124}$

Az osztag egyik akciócsoportja időközben 250 före gyarapodott. Így az akciócsoporton belül három különítményt hoztak létre. Ez az akciócsoport Sólak és Csontos között felrobbantott egy vasúti szerelvényt, melynek következtében egy mozdony, nyolc nyitott és két zárt vasúti kocsi kisiklott és megrongálódott. 1944. X. 6-án robbantást hajtottak végre a Havasköz-Sóhát közötti keskenynyomtávú vasútvonalon. A front közeledése miatt ezt a vonalszakaszt már nem állították helyre. 1944. X. 12-én Sóhát és Szemere közötti, déli irányba vezető hegyi úton a partizánok felégettek egy fahidat. 1944. X. 13-án egy honvéd század egy nyilaskeresztes századossal az élen bevonult Havasközre. A partizánok 1944. X. 14-én hajnalban megtámadták a honvéd századot. A honvédek közül 32 fö elesett, 17 fö fogságba esett. Ezt követően egy partizán akciócsoport maradt a faluban, a többiek a Vörös Hadsereg egységei elé indultak. 1944. X. 28-án beolvadtak a 761. lövészezredbe. Az egyesüléskor a Havasköz térségében táborozó partizánok két géppuskával, hat golyószóróval, három géppisztollyal, 116 puskával, egy aknavetövel, 10 pisztollyal rendelkezett. A Vörös Hadseregnek 274 foglyot adott át. ${ }^{125}$

TKANKO szovjet ejtöernyös partizán osztag élelmiszerbegyüjtő akciói a Róna-havason tovább folytatódtak. 1944. X. 10-én ismét Patakosra (Ungvár K $18 \mathrm{~km}$ ) tört be egy nagyobb partizán csoport. A térségbe kivezényelt csendörök és honvédek hosszabb tüzharcot vívtak a jól felfegyverzett ellenséggel szemben. A harcban négy fő csendőr elesett egy fő megsebesült, három fő pedig a partizánok fogságába esett, őket elhurcolták. Ugyanezen a napon a partizánok ettől a helytől 15 km-re, északra, Turjavágáson raboltak élelmiszert, 1944. X. 16-án pedig a 10 km-re, északnyugatra fekvő Antalócon rekviráltak ennivalót. ${ }^{126} \mathrm{~A}$ lakosság folyamatos zaklatása miatt a hatóságok még egy kísérletet tettek, hogy távozásra kényszerítsék a Róna-havas déli körzeteibe betörő partizánokat. 1944. X. 18-án kisebb létszámú honvéd és csendőr alakulatokat helyeztek ki a térség településeire. A következő napokban azonban a front közeledését kihasználva, a partizánok megtámadták ezeket az alakulatokat. Túrjasebes és Patakos településeken éjszaka rajtaütöttek. Patakoson a honvédek éberek voltak, lövöldözés kezdődött, melynek során két partizán meghalt. Turjasebesen viszont váratlanul, a vendéglöben vacsorázva érte a támadás az ott lévő, csendőrökkel megerősített honvéd szakaszt. A partizánok hangtompítós puskával lelőtték az őrt és kézigránátokkal árasztották el a vendéglöt. Több honvéd és csendör meghalt, illetve megsebesült. Két nappal később kiürítette a körzetet, mert az arcvonal már csak néhány kilométerre húzódott. ${ }^{127}$

1944. X. 23-án egy honvéd utász szakasz érkezett Turjavágásra. A szakaszt a TKANKO szovjet ejtöernyős partizán osztag három akciócsoportja bekerítette. Meg akarták szerezni az utászoknál lévő robbanóanyagot. Megadásra szólították fel őket, a honvédek ellenálltak, de a nagyobb tüzerő legyőzte őket. Több katona elesett vagy megsebesült. A partizánok kilenc foglyot ejtettek, akikkel a táborukba vitették a robbanóanyagot. Az összecsapásban egy fö partizán is megsebesült. ${ }^{\mathbf{1 2 8}}$

1944. X. 26-án, amikor a szovjet csapatok bevonultak Munkácsra, a TKANKO szovjet ejtőernyös partizán osztag azt a parancsot kapta, hogy küldjön partizánokat a Munkács-Ungvár közötti föút közelébe, hogy megzavarják a magyar és német csapatok visszavonulását. Az osztag három akciócsoportja Alsószlatina térségében (Ungvár DK $15 \mathrm{~km}$ ) bekerítettek egy leharcolt magyar honvéd zászlóaljat. Rövid tüzharc után a honvédek feladták a küzdelmet, egy részük elmenekült, sokan a partizánok fogságába estek. A Beregszőlős-Cserhát közötti erdei úton (Munkács ÉK $8 \mathrm{~km}$ ) a partizánok tüzet nyitottak egy tüzérségi oszlopra. A honvédek rövid ellenállás után a lövegeket hátrahagyva a fóútvonal felé elmenekültek. Az ütőképes csendőr alakulatok fronton való alkalmazását és kivérzését kihasználva, illetve a szovjet csapatok gyors közeledésére építve a nagy létszámú partizán osztagok szabadabban mozogtak és aktívabb tevékenységet folytattak. A TKANKO szovjet ejtöernyős partizán osztag 1944 október végére már 883 főből állt, akik 13 akciócsoportba szerveződve hajtottak végre akciókat, és mintegy 600 szimpatizáns civil lakos támogatta őket titokban. Fegyverzetükbe hét géppuska, 24 golyószóró, 141 
géppisztoly, 657 puska, 39 pisztoly, két aknavető és mintegy 100000 töltény tartozott, és egyéb katonai felszerelés mellett hat rádióállomással rendelkeztek. ${ }^{\mathbf{1 2 9}}$

A szovjet föerőkkel szemben azonban a könnyü fegyverzetü csendőr alakulatoknak nem volt reális esélye. Az ungvári tanzászlóalj két századát 1944. X. 6-án riadóztatták, alárendelték az 1. hadsereg 13. hadosztályának, és azonnali menetparancsot kaptak, hogy vonuljanak fel a Vereckei-hágó védelmére. A 130 fős századok fegyverzete egy géppuska, három golyószóró, 15 géppisztoly, 110 puska és 12 pisztoly, valamint 500 kézigránát volt. 1944. X. 7-8-án a csendörök Alsó- és Felsőverecke települések körzetében harcoltak a nagy túlerőben lévő páncélosokkal támogatott szovjet erőkkel, majd 1944. X. 8-án visszavonultak az Árpád-vonalba, ahol 1944. X. 10-ig folytatták a küzdelmet. Mivel elfogyott a lőszerük, az állásokat fel kellett adniuk. Miután azonban lőszerutánpótláshoz jutottak, visszafoglalták korábbi állásaikat, és a kivonásukig kitartottak. Az 1944. 7. és 1944. X. 17. között zajló, 10 napos egyenlőtlen harcban a csendőr zászlóalj 50\%-os veszteséget szenvedett. A következő napokban az 1. század Munkács előterében rendezkedett be védelemre, a 2. századot pedig kivezényelték a Borló-hegység partizánjai elleni tisztogató akcióra. Egy héttel később a két század Ungvár védelménél újra egyesült. 1944 október végén a zászlóalj parancsot kapott, hogy a megmaradt csendőröket indítsa útnak Budapestre. Ekkorra azonban az eredeti személyi állománynak már csak 20-25\%-a volt harcképes. A főváros védelme során ezek nagy része is elesett. ${ }^{\mathbf{1 3 0}}$

1944. X. 14-én és 15-én a BUJANOV szovjet ejtőernyös partizán osztag megérkezett Kárpátaljára, amelyet még 1944. IX. 25-én Szvjatosinoban állították össze. 1944. X. 6-tól azonban az északkeletmagyarországi ejtőernyős bevetések irányítását átvette a 4. Ukrán Front Partizán Törzse vette át, ezért az osztag tagjait vonaton Sztanyiszlavba küldték. Feladataikat a Sztanyiszlav közeli oprisovcei partizánbázison határozták meg számukra. ${ }^{131} \mathrm{Az}$ osztag személyi állománya eredetileg 29 főből állt (20 magyar és kilenc szovjet) közülük végül 14 magyar és kilenc szovjet partizán került bevetésre. Az osztag müködési területének a Kassa és Sárospatak közötti területet, a Zempléni hegység térségét jelölték ki, faladata katonai felderítés, propaganda és agitáció a lakosság körében és a közlekedési hálózat elleni robbantásos akciók végrehajtása volt. Mivel az ebbe a térségbe ledobott osztagokat a magyar rendvédelem szinte azonnal felszámolta, a BUJANOV szovjet ejtöernyös partizán osztagot biztonságos helyen, a TKANKO szovjet ejtöernyös partizán osztag által ellenörzött területen földre. Ez azonban mintegy 100 km-re volt a Zempléni hegységtöl. ${ }^{132}$

A 4 . Ukrán Front Partizán Törzse előzetesen értesítette a TKANKO szovjet ejtöernyös partizán osztagot a BUJANOV szovjet ejtőernyős partizán osztag érkezéséröl. A TKANKO szovjet ejtöernyös partizán osztag parancsnoka felderítőket küldött ki a leszállási zónát övező körzetbe, hogy összeszedjék az esetleg elsodródó ejtőernyősöket. Az első részleg, 20 fő a Róna-havason szállt le Nádaspatak térségében (Munkács ÉÉK $25 \mathrm{~km}$ ). Hárman közülük a földet éréskor lábukat törték, kettejük pedig messzebbre sodródott, de néhány órán belül mindenkit megtaláltak. Másnap este egy újabb repülőgép érkezett, amely a csoport hátra maradt négy tagját, és nagyobb mennyiségü felszerelést, robbanóanyagot, löszert, élelmiszert hozott a BUJANOV szovjet ejtőernyös partizán osztagnak, amely két napot a táborában töltött, majd 1944. X. 18-án este, a sérülteket hátrahagyva Sárospatak felé indult. ${ }^{133}$

Árok község közelében a csoport beleütközött az ókemencei csendőr őrs megerősített járőrébe. Bár a partizánok fölényben voltak igyekeztek kitérni a további harc elől. Az erdőn keresztül végrehajtott éjszakai menet során öt fő elszakadt a többiektől, magukra maradva felhúzódtak a hegyekbe. Elsősorban a helyi lakosság körében folytattak propaganda tevékenységet. Egy Kelet-Szlovákiában müködő partizán osztag felderítőivel összetalálkoztak, és egy időre csatlakoztak ehhez az osztaghoz, így ki tudták egészíteni a készleteiket. A BUJANOV szovjet ejtőernyős partizán osztagtól lemaradók azonban nem akarták elhagyni Ungvár körzetét. Ezért amikor 1944. X. 15-én tudomást szereztek arról, hogy idősebb korosztályhoz tartozó póttartalékos őrszakasz a közelben teljesített szolgálatot, rábeszélte őket, hogy adják át a fegyvereiket és menjenek haza. Csatlakozó helyi lakosokkal és néhány katonaszökevénnyel a leszakadt partizánok száma 1944. X. 20-ra már 35 före növekedett. 1944. X. 28-án találkoztak a Vörös Hadsereggel. ${ }^{134}$

A BUJANOV szovjet ejtőernyös partizán osztagt kettészakadásával az osztag fö ereje is nehéz helyzetbe került, mert a leszakadók ismerték a biztonságos útvonalat és azokat a konspirációs kapcsolatokat, akiknek segíteni kellett volna abban, hogy eljussanak Sárospatakig. Mivel nem lehetett tudni, hogy a leszakadókat nem fogták-e el, és az Ungvár-Perecsény út mentén - amelyen át kellett volna kelniük erős volt a katonai jelenlét, ezért az osztag parancsnoka úgy döntött, hogy egyelöre nem mennek tovább, hanem Rohonca (Ungár ÉK $10 \mathrm{~km}$ ) körzetében maradnak. Felvették a rádiókapcsolatot a 4. Ukrán Front Partizán Törzsével, amely jóváhagyta a döntését és az Ungvár-Perecsény közötti katonai forgalom megfigyelésére utasította az osztagot. ${ }^{135}$ 1944. X. 10-én BUJANOV szovjet ejtőernyös partizán osztag felderítői szovjet területre igyekvő, 50 fős szlovák katonai alakulattal találkoztak, amely a csehszlovák 
hadtesthez akart csatlakozni. Néhány partizán átkísérte a szlovák katonákat a határon. A partizánok sok időt fordítottak a propagandára, a helyi ruszin lakosság meggyőzésére, hogy forduljanak szembe a magyar és német hatóságokkal. Többen csatlakoztak az partizánokhoz, melynek létszáma 1944 október közepére 70 före nőtt. 1944. X. 18-án összecsapásra került sor a partizánok, illetve honvéd-csendőr vegyesjárőr között. A tüzharcban egy fö partizán elesett, az osztag parancsnoka pedig megsebesült, így annak vezetését a helyettese vette át. ${ }^{\mathbf{1 3 6}}$

A partizánok felderítették, hogy Rohoncán 10 honvédből álló rajt szállásoltak el. 1944. X. 20-án 13 partizán lement a faluba ahol bekerítették és lefegyverezték a honvédeket. Utána élelmiszert rekviráltak a lakosságtól. Két honvéd azonban nem tartózkodott a körletben, visszatérve észlelték a partizánokat, a szomszédos Felsődomonyára siettek és jelentették az esetet. Hajnalban két német szakasz érkezett Rohoncára. Rövid tüzharc után a partizánok a zsákmányolt élelemmel és fegyverekkel (egy golyószóró, két géppisztoly, öt puska) elvonultak. A németek nem üldözték öket a hegyekben, a partizánok mégis úgy döntöttek, hogy egyelöre visszatérnek a Róna-havas belsejébe. Néhány nappal később egy visszavonulóban lévő leharcolt honvéd zászlóalj trénoszlopa haladt el Nádaspatak közelében. partizánok aknákat telepítettek az útra, lesállást foglaltak, és rajtaütöttek a 48 emberböl álló oszlopon. Az aknák robbanására és a géppisztolytüzre a honvédek szétfutottak az erdőben. A partizánok több foglyot is ejtettek, akiket kikérdeztek, és a szerzett információkat továbbították Sztanyiszlavba. Ekkora az osztag létszáma csatlakozó katonákkal és a helyi lakosokkal együtt mintegy 30 före emelkedett. ${ }^{137}$

1944. X. 20-án átkeltek az Ung folyón, és Ungvár közelébe húzódtak. 1944. X. 22-én Ungdaróc közelében (Ungvár DNY $3 \mathrm{~km}$ ) robbantást hajtottak végre, megrongáltak egy kisebb vasúti hidat. 1944. $X$. 24-én éjszaka támadást intéztek a városi villanytelep ellen. A telepen éjszaka négy fős őrség tartózkodott, két fő német katona és két fő német szolgálatban álló hucul. A partizánok előző nap rábeszélték a két hucult, hogy robbantsák fel a telep $600 \mathrm{~kW}$ teljesítményü dinamóját, amit azok a szovjet csapatok közeledésének hatására meg is tettek. Az akciónak azonban sok értelme már nem volt, ugyanis két nap múlva a Vörös Hadsereg bevonult Ungvárra, és az áramkiesés már nekik okozott gondokat. A partizánok 1944. X. 24-én még parancsot kaptak arra, hogy vonuljanak Csap körzetébe és ott folytassanak diverziós tevékenységet. Erre azonban már nem került sor. A szovjet csapatok előrenyomulása folytán, 1944. X. 28-án a partizánok találkoztak a Vörös Hadsereggel. ${ }^{138}$

A Kárpátalján harcoló 12 fös BUJANOV szovjet ejtőernyős partizán osztag eredeti létszáma, a bevetés időszakában 166 före gyarapodott. Tevékenységük során mintegy 1200 föt tudtak bevonni a fegyveres harcba, és közel 1500 szimpatizáns támogatta őket, elsősorban az ukrán és ruszin lakosság köréből. ${ }^{139}$

\section{Partizántevékenység a Felvidéken}

Az Észak-Magyarországon és a Felvidéken folyó partizántevékenység számára fontos hátteret jelentett, hogy 1944 nyarán szovjet részről jelentős partizánerőket vetettek be szlovák területen, kiaknázva a magasabb hegységek és nagyobb erdőségek adta lehetőségeket. 1944 nyarán 24 szovjet ejtőernyős partizán osztagot dobtak le Szlovákiában, megközelítőleg 400 fővel. Ezek célja a felderítő és diverziós tevékenység mellett a szlovák lakosság mozgósítása volt a németellenes harcra. A szovjet ejtőernyős partizán osztagok jelentős szerepet játszottak az 1944. VIII. 29-én kirobbanó szlovák nemzeti felkelés előkészítésében és katonai megszervezésében. A Besztercebánya-Liptószentmiklós-Breznóbánya térségében müködő szovjet ejtőernyös partizán osztagok közül a három legjelentősebb - JEGOROV szovjet ejtöernyös partizán osztag, VOLJANSZKIJ szovjet ejtöernyös partizán osztag és VELICSKO szovjet ejtöernyös partizán osztag - tevékenységei magyar területeket is érintett. ${ }^{140}$

A 22 partizánból álló JEGOROV szovjet ejtőernyős partizán osztagot 1944. VIII. 6-án vetették be, és 1944. VIII. 28-án már több mint 600 föt számlált. A 15 fős VOLJANKSZKIJ szovjet ejtőernyős partizán osztag 1944. VIII. 6-án szállt le Szlovákiában és 1944. VIII. 28-án már 500 fővel, 1944. IX. 14-én pedig már 1384 fővel rendelkezett, ekkor elnevezték magukat a „Szlovákok szabadságáért” dandárnak. A 11 fös VELICSKO szovjet ejtöernyös partizán osztag 1944. VIII. 7-én ért földet a Felvidéken és 1944. VIII. 28-án már 360 före gyarapodott, 1944. X. 1-jén pedig az osztag létszáma már meghaladta az 1000 embert. 1944 október elején, szlovák területen hat jelentősen megerősödött szovjet ejtőernyős partizán osztag és 20 kisebb önálló szovjet ejtőernyős partizán osztag tevékenykedett összesen 15845 fönyi létszámmal. 1944 november végére a szovjet ejtőernyős partizán osztagok személyi állománya elérte a 17009 fö́t. 1944. október-november folyamán a partizánok 12596 ellenséges katonát kapcsoltak ki a harcokból (halott, sebesült, fogoly) 47 vasúti szerelvényt siklattak ki, 20 harckocsit, 22 repülögépet, 260 gépjármüvet semmisítettek meg, 22 vasúti 30 közúti hidat és átereszt robbantottak fel. ${ }^{\mathbf{1 4 1}}$

A PUT a magyar kommunista vezetők javaslatai nyomán 1944 augusztusától fokozott figyelmet fordított az észak-magyarországi bánya- és ipartelepek térségében a partizántevékenység 
megszervezésére. ROSENFELD (RÁKOSI) Mátyás és társai azt állították, hogy a Salgótarján-Ózd-Diósgyőr körzetében kibontakozó partizán mozgalom mozgósítani fogja az ottani németellenes érzelmü munkásságot, ami a haditermelés érzékelhető visszaesését eredményezheti, illetve az ország egyetlen gerillaharcra alkalmas, hegyes, erdős régiójában jelentősebb fegyveres ellenállást teremthet. Mivel a szovjet katonai vezetés már számolt a szlovák nemzeti felkelés kirobbanásával, ezért a PUT is hasznosnak ítélte, ha a Szlovákiával szomszédos salgótarjáni, ózdi és diósgyőri körzetben nagyobb partizánbázist sikerül kiépíteni. A magyar kommunista vezetök által festett képnek azonban nem volt reális alapja. A viszonylag jól járható hegyek és az egybefüggően nem túl nagy, könnyen áttekinthető erdők nem kedveztek a magyarországi partizánharc számára, és a lakosság, még a nagyipari munkásság sem fogadta túlzott bizalommal a szovjet ejtőernyősöket. ${ }^{\mathbf{1 4 2}}$

1944. VIII. 8-án nyolc magyar és öt szovjet partizánból álló SZÖNYI szovjet ejtöernyös partizán osztag került bevetésre Tarnalelesz közelében (Ózd DNY $20 \mathrm{~km}$ ). ${ }^{143}$ Feladatuk olyan központi bázis kiépítése volt, ahol újabb csoportokat és hadianyagot fogadhattak és agitációs tevékenységet fejthettek ki a térség munkásai körében, ellenállásra, szabotázstevékenységre mozgósíthattak, felderítési információkat gyüjthettek a körzetben müködő hadiipari üzemekröl, illetve diverziós tevékenységet is megvalósíthattak, elsősorban a közlekedési útvonalak, a hadiszállítások ellen. ${ }^{144} \mathrm{Az}$ osztag földet érésekor több ejtőernyős fákra zuhant és megsérült, az utolsóként ugró három fö pedig észak felé messze elsodródott és a hegyvonulat másik oldalán, Domaháza közelében szállt le, a többiektől 15 km-re. A partizánok kézre kerítésére a hatóságok nagy erőket mozgósítottak, két század honvédet, egy szakasz csendőrt a VII. miskolci csendőr kerület ózdi szárnyától, és az ejtőernyős-elhárító szolgálat helyi alakulatait, melyek lezárták a leszállási hely körzetét. 1944. VIII. 10-én a járdánházai erdészlak közelében a kutatást végző 12 honvéd és az ózdi csendőr szárny 1. szakaszának 11 csendőre rátalált az ejtőernyősökre. A kialakuló tüzharcban két fö partizán megsebesült. Menekülés közben a partizánok felszerelésük nagy részét eldobálták. 1944. VIII. 11-én a honvédek elfogták az osztagtól elszakadt három föt. 1944. VIII. 12-én heves tủzharc bontakozott ki a kereső alakulatok és az ejtőernyősök között Dobronya-Padostető térségében, de partizánok automata fegyvereikkel fel tudták tartóztatni az üldözőket, és ismét egérutat nyertek. ${ }^{\mathbf{1 4 5}}$

1944. VIII. 17-én a SZÖNYI szovjet ejtőernyős partizán osztag parancsnoka két társával felderítésére indult, de a Domaháza-Hangony müút térségében, Laczópadjánál tüzharcba keveredtek. Mindhárman megsebesültek, közülük két fö később belehalt sérüléseibe, a könyebben sérült parancsnok visszamenekült az erdőbe. A magára maradt csoporton belül vita alakult ki. A magyarok el akartak rejtőzni, hogy kivárják a felkutatásukra indított keresőakciók befejezését, a szovjetek viszont a biztonságosabb szlovák területekre akartak átvonulni. Az osztag szétesett, a magyarok elszéledtek, próbáltak hazajutni, a szovjetek pedig észak felé indultak, és többnapi gyaloglás után a szlovák partizánok által ellenőrzött területre értek, ahol csatlakoztak a JEGOROV szovjet ejtőernyős partizán osztaghoz. ${ }^{\mathbf{1 4 6}}$

1944. VIII. a PUT erösítést küldött a SZÖNYI szovjet ejtőernyös partizán osztag számára, nem tudva, hogy az egység már nem létezik. Domaháza-Gesztete térségében négy szovjet és nyolc magyar ejtőernyős ereszkedett le. A SZŐNYI szovjet ejtőernyős partizán osztag felkutatása céljából a körzetben tartózkodó ózdi csendőrök az újonnan leszállt partizánok keresésére indultak. Másnap megtalálták őket és heves tüzharcban hat partizánt megöltek, hat föt pedig elfogtak. ${ }^{147}$

1944. VIII. 30-án, Feleden igazoltatás során egy csendőr járőr letartóztatta a SZŐNYI szovjet ejtöernyös osztag egyik tagját. 1944. IX. 2-án pedig a rudabányai csendőr örs elfogta a SZÖNYI szovjet ejtőernyős partizán osztag hazatérő két tagját. Az osztag-parancsnok három hétig egyedül kóborolt a környéken, a helyi lakosoktól szerzett élelmet, tanyák gazdasági épületeiben húzta meg magát éjszakára. 1944. IX. 7-én hajnalban az ózdi csendőr szárny 2. szakasza és a hangonyi csendőr örs személyi állományába tartozó nyolc csendőr a Kissikátor melletti Macska-tanyán rajtaütött a bujkáló partizánon és mivel ellenállást tanúsított, lelőtték, így az osztag maradványát is felszámolták. ${ }^{\mathbf{1 4 8}}$

1944. VIII. 29-én, jelentős szovjet közremüködéssel kirobbant a szlovák nemzeti felkelés. A szovjet hadvezetés 1944. IX. 8-án megindította a Kárpátok-Dukla hadmüveletet, melynek célja a Duklai szoroson áttörve Kelet-Szlovákia, Eperjes térségének elfoglalása volt. Az offenzíva föcsapást az 1. Ukrán Front 38. hadserege és a 4. Ukrán Front 1. gárdahadseregének részei mérték. A szovjet hadvezetés remélte, hogy a szlovákiai felkelés, a Felvidéken müködő nagyszámú partizán osztag komolyabb segítséget tud nyújtani a Vörös Hadsereg előrenyomulásához, naprakész felderítési adatokkal, az ellenség hadiszállításának akadályozásával, a közbiztonság megzavarásával és annak helyreállítására nagyobb fegyveres erő hátországbeli lekötésével. Ezért a PUT újabb ejtőernyős partizán osztagokat dobott le a Felvidéken. Az új osztagok egy része a felkelők által elfoglalt területen, viszonylagos biztonságban érhetett földet, és rövid pihenés és felkészülés után indult útnak a saját feladata teljesítésére. 1944. IX. 1jén került bevetésre a 39 főből - magyar, osztrák, cseh, szlovák, orosz és ukrán származású katonákból 
—álló SZAGYILENKO szovjet ejtöernyös partizán osztag, amely Szepesapátka (Kassa ÉNY 15 km) körzetében ért földet, a MARTINOV szovjet ejtőernyös partizán osztag által ellenörzött területen. Az osztagot három részletben dobták le a Felvidéken. ${ }^{149}$

Az első csoportban hét szovjet és hét magyar ugrott. ${ }^{150}$ A leszállásnál egy fö megsérült, fennakadt egy fán, és amikor elvágta az ejtő́ernyő köteleit, lezuhant a földre, mindkét lábát eltörte. Reggel eszméletlen állapotban találtak rá a többiek. Az orvos sínbe tette, és ideiglenesen egy erdészházban helyezték el. Később magukkal vitték a felkelők egyik repülőterére és egy hadianyagot hozó szovjet szállítógépen visszaküldték Kijevbe. A SZAGYILENKO szovjet ejtöernyős partizán osztag, második része 1944. IX. 13án, a harmadik része pedig 1944. IX. 16-án szállt le ugyanabban a körzetben. 1944 októberben a felkelés ellen harcoló német csapatok nyomása jelentősen megerősödött, ezért a SZAGYILENKO szovjet ejtöernyös partizán osztag, nyugatra vonult, Breznóbánya térségébe, és a várostól délre, hét km-re, Feketebalogon rendezkedett be. 1944. X. 15-én az osztag már 104 főből állt. 1944 november végére pedig létszámuk 303 före gyarapodott, köztük 71 fö volt magyar. ${ }^{151}$

1944. XII. 2-án a csoport kiszabadította a Szinóbányán (Losonc É $15 \mathrm{~km}$ ) állomásozó munkaszolgálatos zászlóalj 300 tagját. Foglyul ejtettek a keretből 15 honvédet, felvették az egyenruhájukat, és így agitálták a keret többi tagját, hogy nincs értelme a fegyveres ellenállásnak. A keretlegénységet végül lefegyverezték, a munkaszolgálatosok közül 80 fö csatlakozott a SZAGYILENKO szovjet ejtöernyös partizán osztaghoz, a többiek szétszéledtek. Ezt követően a magyarokból század elnevezéssel önálló akciócsoportot állítottak fel. Az osztag egy másik, ugyancsak század elnevezésű akciócsoportjában mintegy 50 fö magyar partizán harcolt. 1945 januárjában a SZAGYILENKO szovjet ejtőernyös partizán osztag dandárrá nevezte át magát. Az alakulat állományába 1945. I. 10-én 485 fő szlovák, 355 fő orosz, ukrán és 174 fö magyar partizán tartozott. ${ }^{152}$

A magyar kommunista vezetés szorgalmazására a PUT továbbra is foglalkozott az észak-magyarországi iparvidéken létrehozandó partizánbázis gondolatával. A SZŐNYI szovjet ejtőernyős partizán osztag és az utánpótlásként ledobott osztag sorsáról Kijevnek még nem volt világos képe, ezért újabb bevetést határoztak el. A szvjatosinoi táborban 1944 szeptember elején arra készültek, hogy hét orosz, 15 szlovák és cseh partizánból álló osztagot dobjanak le szlovák területen. ROSENFELD (RÁKOSI) Mátyás és a NÓGRÁDI szovjet ejtőernyős partizán osztag azirányú sürgetésére azonban, hogy Észak-Magyarországon mielöbb épüljön ki egy partizánközpont, a PUT parancsnoka úgy döntött, hogy a KUZNYEC szovjet ejtőernyös partizán osztagot inkább Magyarország területén fogja bevetni. Tervezték további osztagok ledobását is a Salgótarján-Ózd-Diósgyőr hadiipari centrum körzetében. A KUZNYEC szovjet ejtöernyös partizán osztag sikeres bevetése esetén bevetették volna Salgótarján térségében a SÓLYMOSI szovjet ejtöernyös partizán osztagot is, továbbá Ózd közelében a PALÁSTI-HARSÁNYI szovjet ejtöernyös partizán osztagot, valamint Diósgyőr határában pedig a MARKOVICS szovjet ejtöernyős partizán osztagot. 1944. IX. 2-án KUZNYEC szovjet ejtöernyös partizán osztag parancsnoka utasítást kapott arra, hogy a partizániskola növendékeiből állítson fel három 20 fös osztagot, úgy, hogy a törzs-parancsok, a felderítő-parancsnok, a robbantó, a rádiós és az egészségügyi személyzet minden egységben orosz legyen, a többiek pedig magyarok. Az elképzelés az volt, hogy a három osztagot egymás után bevetve egy nagyobb bázist alakítanak ki Salgótarján-Ózd-Miskolc-Eger térségében. ${ }^{153}$

A KUZNYEC szovjet ejtöernyös partizán osztag feladata, részben az volt, hogy készüljön fel további ejtőernyős osztag fogadására, folytasson folyamatos felderítést a helyi hadiipar tevékenységéről. Emellett, hajtson végre diverziós akciókat a közúti és vasúti szállítás, illetve a helyi közigazgatás, csendör őrsök, és honvédségi létesítmények ellen, valamint folytasson széleskörü agitációs tevékenységet a lakosság körében, és vegyen rá minél több embert, hogy csatlakozzon a partizánokhoz. Az osztag orosz tagjai nem örültek az új feladatnak, hogy nem szlovák területen kerülnek ledobásra, ahol több támogatásra számíthatnának és tudnának kommunikálni a helyi lakossággal. A szovjet ejtőernyős osztag parancsnoka 1944. IX. 5-én személyesen igyekezett meggyőzni őket arról, hogy a magyar lakosság is szimpátiával fogadja majd őket. A KUZNYEC szovjet ejtöernyös partizán osztag elsőként bevetésre kerülö csoportjába nyolc szovjet és 13 magyar tartozott. ${ }^{154} \mathrm{~A}$ magyar és az orosz részleg tagjai nem ismerték egymást, csak a bevetés előtt találkoztak, és nyelvi akadályok miatt a tolmács kivételével beszélni sem tudtak egymással. A magyar részleg parancsnoka a saját embereit sem ismerte, három nappal a bevetés előtt találkozott velük először. Az ejtőernyősök felszereléséhez egy golyószóró, 20 géppisztoly (háromhárom tárral), egy távcsöves, hangtompítós puska négy pisztoly és 40 kézigránát tartozott. A ruházatuk vegyes volt, magyar és orosz ruhadarabokat egyaránt viseltek. A KUZNYEC szovjet ejtöernyös partizán osztag parancsnokát amerikai dollárral, a magyar részleg parancsokát pedig német márkával látták el (föként élelmiszervásárlási céllal), pengőt viszont egyikőjük sem kapott. ${ }^{155}$ 
1944. IX. 7-én a KUZNYEC szovjet ejtőernyős partizán osztag két PSZ-4747 szállítógéppel indult útnak Kijevből. Az egyik gépen tartózkodott az osztag parancsnoka és öt orosz, valamint négy magyar partizán. Ez a gép szállította az ejtőernyős zsákba a robbanóanyagot, a tartaléklőszert, az élelmiszert és az egészségügyi felszerelést is. A második gépen kapott helyet kilenc magyar, valamint két orosz partizán. A tervek szerint a ledobás centruma Istenmezeje lett volna (Salgótarján K $20 \mathrm{~km}$ ), bár a célterületet alaposabb helyismeret nélkül találomra választották ki a térképen. Az első gép a front felett erős légvédelmi tüzet kapott, valamelyest eltért az útiránytól, és a tervezettöl 14-15 km-re, délkeletre, a Tarnalelesz-Fedémes-Egerbocs-Szúcs által határolt erdős területen dobta le az ejtőernyősöket. Már ugrás elött baleset történt a gépen, az osztag részeg felderítő parancsnoka ráesett az egyik magyar partizán lábára, akinek így sérülten kellett ugrania. A földet érés után nem találtak meg két partizánt és az egyik ejtőernyős zsákot sem. A megtalált zsákot pedig el kellett ásniuk, mert 4 ember kellett volna a cipeléséhez. Elvesztették továbbá a rádió tartalék telepjeit is, így nem sikerült kapcsolatba lépniük Kijevvel. Az ejtőernyősök leszállását a hatóságok azonnal felfedezték, és mozgósították az ejtőernyős-elhárító szolgálatot, az Egerben állomásozó gyalog zászlóaljat, illetve a körzet csendőr őrseit, mindenekelőtt a tarnaleleszi és az egercsehi örsöt. ${ }^{156}$

Az egyik ejtőernyős partizán felszerelését hátrahagyva megkísérelte eladni az ejtőernyőjét az aranyosi útkaparónak, hogy ételt és italt vehessen az árán. Az útkaparó bejelentése nyomán az egercsehi csendőr őrs járőre a leszállást követő egy-két órán belül elfogta a partizánt. Az üldözés miatt az osztag folyamatosan menekült, ÉK irányában. A sérült lábú partizán és két magyar társa lemaradt az oroszoktól. Mivel a sérült magyar partizán egy idő után már nem tudott menni, külön-külön próbáltak elrejtőzni az erdőben. Az osztag-parancsnok és négy embere tüzharcba keveredett a csendőrökkel és a honvédekkel. A rádiós súlyos sebesülten hátra maradt, a parancsnok és három fö viszont ki tudott törni a bekerítésböl. A terület átfésülése során az egercsehi csendőr őrs járőrei elfogtak két partizánt és bevitték Egercsehibe. Egyikük másnapra belehalt a sebesülésébe. 1944. IX. 9-én az egri helyőrség egyik alegysége elfogta az erdőben bujkáló partizánok egyikét, és mint áruló katonaszökevényt a helyszínen agyonlőtték. A honvédek megtalálták az osztag ejtőernyőit, a felszerelést tartalmazó zsákot, a rádiót, és azokat bevitték Egercsehibe. A partizánharcban járatlan honvédek több alkalommal is tüzet nyitottak a keresésben résztvevő más honvéd alakulatokra. Ennek során egy honvéd életét vesztette. ${ }^{157}$

1944 IX. 10-én KUZNYEC szovjet ejtőernyös partizán osztag egyik bujkáló és éhező tagja bement egy házba Egercsehiben. Adtak neki enni, de rábeszélték, hogy jelentkezzen önként a csendőrségen, mert az őrs-parancsnok korrekt ember. A partizán feladta magát. Nem esett baja, 1944. IX. 11-én beszállították Miskolcra, a 7. csendőr kerület nyomozó alosztályára. Ugyanezen a napon az osztag paracsnoka a megmaradt három emberével Egercsehitöl ÉK irányban öt-nyolc km-re, Bekölce, Balaton községek körzetében rejtőzött. Ezt követően nyugat felé indult, Istenmezeje-Váraszó térségébe, a ledobás tervezett helyére. 1944. IX. 11. és 1944. IX. 16. között ott szerették volna megtalálni a második gépen érkező partizánokat. A salgótarjáni határvadász zászlóalj alegységei azonban folyamatosan kutatták a környéket, ezért a partizán iosztag már ledobott és megmaradt része mivel újonnan érkező társaik nyomát sem találták, ezért szlovák terület felé indultak, és északkeleti irányában elhagyták Magyarországot. ${ }^{\mathbf{1 5 8}}$

KUZNYEC szovjet ejtőernyös partizán osztag második részét szállító repülőgép az első gép után egy órával indult Kijevből. Ez a gép is erős légvédelmi tüzet kapott a front térségében, ezért a ledobás a tervezett helytől 20 km-re, északra, Gesztete-Ajnácskő térségében történt. Egyikőjük fennakadt egy fán és súlyos sérüléseket szerzett, eltört a bordája. Egy másik partizán is egy fára zuhant, mire levágta magát és lejutott a földre megsérült a lába és eltört a keze. Mások is fákra érkeztek, de szerencsésebbek voltak, és épen jutottak le a földre. Az osztag újonnan érkezett részének a vezetője - miután megállapította, hogy hol vannak - délre indította a partizánokat a tervezett ledobási helyükre, hogy egyesüljenek a másik részleggel. A vonuló partizánok beleütköztek a gesztetei főjegyző által vezetett kisebb ejtőernyőselhárító alakulatba, amely néhány vadászból, erdőőrből, és leventékből állt. Lövöldözésre nem került sor, a föjegyző csapata látva az automata fegyverekkel felszerelt csoportot, gyorsan visszavonult. Viszszaérve a faluba azonnal értesítette a feledi csendőr őrsöt és erősítést kért tőlük. A partizánokat az erdökerülő vezette át egyik erdőből a másikba, hogy észrevétlenek maradjanak. Időközben két erdész megtalálta a sebesült partizánt és jelentette a feledi csendőr őrsnek. 1944. IX. 8-án elfogták a sebesültet és az egyik fán fennakadt partizánt is. Két partizán a többiektől még északabbra ért földet, mert az ugrás elött egyikük meggondolta magát és nem akarta elhagyni a gépet. Az orosz személyzet némi huzavona után egyszerüen kilökte a szállítóból. ${ }^{159}$

1944. IX. 10-én a KUZNYEC szovjet ejtöernyös partizán osztag újonnan érkező része Zabar község mellett táborozott. Egyikőjük bement a faluba, hogy élelmet szerezzen, de nem ment vissza társaihoz. Mivel reménytelennek látta ezt az erdei küzdelmet, civil ruhát szerzett és hazament Újpestre, ahol saját 
ellenálló csoportot szervezett. Az üldözők éjszaka utolérték az osztag újonnan érkezett részét, akik rövid tủzharc után déli irányba menekültek. A két orosz elszakad tőlük. Már korábban is volt némi vita, mivel az oroszok a jobb feltételeket nyújtó szlovák területek felé akartak menni, míg magyar partizánok Magyarországon akart maradni. Az oroszok ezért önállósították magukat, és át is jutottak Szlovákiába. Az egyik magyar partizán szintén leszakadt és eltévedt, 1944. IX. 11-én hajnalban elfogták a csendőrök. ${ }^{\mathbf{1 6 0}}$

Az osztag maradék magyar részlege immár négy emberből állt, akik 1944. IX. 13-án Istenmezeje térségébe értek. Nem tudhatták, de ekkor voltak a legközelebb az osztag többi részéhez, alig öt-hat kmre. Amikor bementek egy tanyára élelemért, a helyiek értesítették a csendőrséget. A pétervásári csendőr őrs hat fős megerősített járöre hamarosan elfogta a partizánokat. 1944. IX. 15-én Miskolcra vitték őket a csendőr kerület nyomozó alosztályához, kihallgatásra. A foglyok később Budapestre, majd Komáromba kerültek, onnan decemberben Németországba indították őket egy nagyobb transzporttal, de öt fö megszökött. Egy fö partizán Sopronkőhidára, három partizán pedig német táborba került és valamenynyien túlélték a háborút. ${ }^{161}$

A 21 fös KUZNYEC szovjet ejtőernyös partizán osztagot hat nappal a bevetés után már teljesen felszámolták. Mindössze öt fö orosz tudott szlovák területre menekülni és két magyar partizánnak sikerült elrejtőzni Magyarországon. 1944. IX. 25-én a miskolci 7. csendőr kerület nyomozó alosztálya körözést adott ki a még szökésben lévő partizánok ellen. Tájékoztatásul közreadta a rendvédelmi szervezetek és a helyi hatóságok számára további 169 olyan ember nevét, akik hadifogságba estek, és valószínúleg antifasiszta iskolába vagy partizánkiképzésre jelentkeztek, így várhatóan a közeli jövőben ejtőernyős bevetésre kerülhetnek magyar területen. ${ }^{\mathbf{1 6 2}}$

1944. IX. 8-án az 1. Ukrán Front 38. hadserege és a 4. Ukrán Front egy lövészhadteste megkezdte a Kárpátok-Dukla hadmüvelet végrehajtását. A szovjet erők Sanok körzetéből támadást indítottak a szlovák határ felé, Komanczán át, Eperjes általános iránnyal. Ennek támogatására a PUT fokozott aktivitásra szólította fel a Kelet-Szlovákiában és Magyarország északkeleti körzeteiben müködő partizán osztagokat. Ezzel párhuzamosan több új ejtőernyős osztagot is ledobtak az érintett térségben. A PUT Homonna körzetében nagyobb partizánbázis kiépítését tervezte, ahonnan Eperjes, Kassa és Ungvár egyaránt elérhető távolságra esett. 1944. IX. 8-án került bevetésre Homonna térségében a „Csehszlovákia szabadságáért" nevet viselő, 16 fős, orosz, szlovák, ruszin partizánokból álló PERECSINSZKIJ szovjet ejtöernyös partizán osztag. ${ }^{163}$

Az osztag leszállását a térségben már müködő CSAPAJEV szovjet ejtöernyös partizán osztagnak kellett volna biztosítania. A német csapatok és szlovák Hlinka-gárdisták azonban ezekben a napokban hajtóvadászatot indítottak a térségben már ténykedő partizán osztag ellen, így az nem tudott segíteni az újonnan érkezőknek. A földet éréskor három fő eltűnt. A leszállást követően a partizánvadász erők azonnal üldözni kezdték PERECSINSZKIJ szovjet ejtőernyős partizán osztagot is. A partizánok keleti irányba, Kárpátalja felé menekültek, és Ugar-Kisberezna körzetében (Homonna K 35-40 km) magyar területre léptek. Az osztag hosszabb pihenőt tartott Újkemence község közelében (Nagyberezna D $10 \mathrm{~km}$ ). A következő hetekben a létszám szökött szovjet hadifoglyok és ruszin lakosok csatlakozásával fokozatosan növekedett, és 1944 október végére elérte a 114 föt. Ennek ellenére számottevő akciót nem hajtottak végre, csak kisebb rajtaütéseket végeztek az Ungvár-Szinna, illetve az Ungvár-Uzsok útvonal mentén a szlovák-magyar határ körzetében, kihasználva, a térségben lévő nagy erdőségek biztosította lehetőségeket. Az osztag 1944. XI. 11-én egyesült a Vörös Hadsereggel. Addig mintegy 300 foglyot ejtett, csapattestüktől leszakadt honvédeket, a fronton szétvert, visszavonuló alakulattöredékek személyi állományát, akik nemigen bánták, hogy számukra véget ért a háború. ${ }^{\mathbf{1 6 4}}$

1944. IX. 9-én a PUT egy újabb osztagot indított Homonna térségébe. A 19 fös „Borkanyuk” elnevezésű MAHARITA szovjet ejtőernyős partizán osztagot. ${ }^{165}$ Az egység müködési körzetét a magyar-szlovák határ mentén az Ungvár-Perecseny és az Ungvár-Szobránc utak térségében jelölték ki. Ezt a csoportot a BERNSTEIN Szovjet ejtöernyős partizán osztagnak kellett volna várnia a leszállásnál, a németek és a Hlinka-gárdisták azonban már elüzték a partizánokat erről a területről. Az ejtőernyősök hetekig rejtőzködtek, majd az üldözők elől kitérve délkeleti irányba indultak és bevették maguk a Vihorlát hegységbe. 1944. X. 19-én Pásztorhegy térségében építettek ki bázist. 1944. XI. 12-én átvonultak a hegység keleti oldalára. A szovjet csapatokkal Oroszsebes községnél találkoztak. A közel két és fél hónap alatt számottevő tevékenységet nem folytattak. ${ }^{\mathbf{1 6 6}}$

1944. IX. 15-én éjszaka a Kárpátok hágóit támadó 4. Ukrán Front Haditanácsa mellett müködő Partizán Törzs egy nagyobb létszámú szovjet ejtőernyős partizán osztagot dobott le Királyhelmec közelében (Csap NY $15 \mathrm{~km}$ ), a Latorica erdőségének déli részén. A 24 fös MOROZOV szovjet ejtőernyös osztagot két gép szállította a célterület fölé. A osztag személyi állományát orosz, szlovák és magyar partizánok alkották. A fegyverzetet két golyószóró, 22 géppisztoly, gey távcsöves puska négy pisztoly és 50 kézigránát 
alkotta. A földet éréskor több ejtőernyős is sérüléseket szenvedett. 1944. IX. 16-án és 1944. IX. 17-én több kisebb tüzrajtaütést hajtottak végre a Csap-Királyhelmec út mentén, Bacska közelében. ${ }^{167}$

Az osztag ezt követően északnyugati irányba indult és 1944. IX. 18-án hajnalban Boly községnél tüntek fel. A lakosság értesítette a hatóságokat, és leküzdésükre a királyhelmeci csendőr őrs személyiállományát, a helyi ejtőernyős-elhárító szolgálat tagjait, valamint magyar és német katonákat vetettek be. A kereső csoport a királyhelmeci erdőben váratlanul bukkant rá a partizánokra. A kialakult tüzharcban három fő csendőr és egy fő német katona elesett, egy fö német katona pedig megsebesült. A partizánok közül a tủzharc során két fő meghalt, három föt pedig elfogtak. ${ }^{168}$

A tüzharc után az ejtőernyősök egy nagyobb csoportja nyugati irányba menekült az erdőn át. A hajtóvadászat ellenük nagyobb honvéd erők bevonásával a következő napokon folytatódott. 1944. IX. 20-án, Zemplén-Céke térségében a bodzásújlaki és a nagykövesdi csendőr őrs járőrei elfogtak újabb három magyar származású partizánt. 1944. IX. 21-én az elfogás helyétől a helytől északnyugatra, 15 km-re, Alsómihályi községnél a helyi csendőr őrs személyi állománya és a 101. honvéd őrzászlóalj egy szakasza összecsapott az ejtőernyősökkel. A tủzharc során két fö partizán meghalt, három fő megsebesült, két fő pedig fogságba esett. Az 1944. IX. 18-ai első ütközet után néhány partizán déli irányba menekült. Közülük 1944. IX. 22-én Dámócnál (Királyhelmec DK $8 \mathrm{~km}$ ) a ricsei csendőr őrs járőre elfogott egy fö fegyverest, két fö menekülőt pedig üldözőbe vett. A MoROZOV szovjet ejtöernyös partizán osztagot tehát, annak ellenére, hogy viszonylag nagy létszámú volt és jelentős tüzerőt képviselt, néhány nap alatt szétszórták, a partizánok felét megölték vagy elfogták. ${ }^{169}$

A PUT tovább kísérletezett, hogy Losonc-Salgótarján térségében egy nagyobb partizánbázist építsen ki. Egyrészt a szlovák felkelők által ellenőrzött területre küldött partizánerők egy részét irányította erre a területre, másrészt közvetlenül is bevetett ejtőernyős osztagokat ebben a körzetben. 1944. IX. 16án este 22 és 23 óra között a rappi csendőr őrs egy járőre Kalonda község (Losonc D 8 km) térségében fegyveres partizánokra bukkant. Túzharc alakult ki, amely nyomán a partizánok visszahúzódtak az erdőbe. A járőr jelentette az idegenek feltünését, ezért másnap a helyi csendőr őrsök, honvéd járőrökkel megerősítve átvizsgálták az egész térséget. Kalondától nyugatra a vilkei csendőr őrs járőre és a kísérő honvédek egy nagyobb, 16 fös szlovák egyenruhás partizán osztagot fedeztek fel. A magyarok tüzet nyitottak, a partizánok két fö halottat hátrahagyva északnyugat felé, szlovák területre menekültek. ${ }^{170}$ 1944. IX. 17-én a PUT egy újabb ejtőernyős osztagot készült bevetni Losonc térségében. A leszállási helyet Gáncs körzetében (Losonc ÉNY 8-10 km) jelölték ki. A szállítógép 18.30-kor szállt fel Kijevböl. A pilóták azonban hosszas körözés után sem találták meg a megadott célterületen a fogadó partizánok által gyújtott jelzőfényeket, így a 14 fős, vegyes nemzetiségü osztagot visszavitték Kijevbe. ${ }^{171}$

Aktív partizántevékenység zajlott a Felvidék középső régiójában is. 1944. IX. 17-én Ipolyfödémes község (Ipolyság ÉK $10 \mathrm{~km}$ ) közelében északról, szlovák terület felöl mintegy 30 partizán jelent meg. Az ipolynyéki csendőr őrs és a honvéd határvadász erők egy megerősített járőre megtalálta és megtámadta a fegyveres csoportot. A partizánok északi irányba visszahúzódtak. Visszavonulás közben egy polgári személyt lelőttek, két főt pedig súlyosan megsebesítettek. Másnap ismét visszatértek Ipolyfödémes közelébe. Elfogtak egy őrségben álló, ejtőernyős-elhárító szolgálatos leventét. Rálőttek a közigazgatási kirendeltség közeledő gépkocsijára, ahol a soför megsebesült. Utána ismét eltávoztak, északi irányba, szlovák terület felé. A leventét később elengedték azzal az üzenettel, hogy a partizánok nem a magyarok ellen akarnak harcolni, hanem csak a németek ellen. ${ }^{172}$

Az észak-magyarországi nagyipari centrumok közelében müködő partizántámaszpont kiépítése érdekében 1944. IX. 18-án két szovjet ejtőernyős partizán osztagot dobtak le szervezési feladatokkal Ózd körzetében. Az első, 12 fös SZMIRNOV szovjet ejtőernyös partizán osztag HANGONY határában (Ózd NY $5 \mathrm{~km}$ ) szállt le. Feladatuk volt, hogy vegyék fel a kapcsolatot a már korábban ledobott SZÖNYI szovjet ejtőernyös partizán osztaggal, illetve a szintén előttük érkezö FJODOROV szovjet ejtőernyös partizán osztaggal. Ezek teljes megsemmisülése a PUT számára még nem volt egyértelmü. Az új osztag további feladata a hadiipari termelés és a katonai csapatmozgások felderítése volt. Az ejtőernyősök robbanóanyagot is vittek magukkal, hogy diverziós akciókat hajtsanak végre a térségben a vasúti és közúti szállítás megzavarására. Az osztag leszállásáról a helyi lakosság már néhány órán belül értesítette a csendőrséget, amely a hangonyi őrs személyi állományával, az Ózdról érkező erősítéssel és az ejtőernyőselhárító szolgálat tagjaival bekerítették a leszállási helyet, és rajtaütöttek a leszállás viszontagságait kipihenő partizánokon. Két fő ejtőernyős meghalt, hat fő fogságba esett. A még menekülésben lévő négy partizánt pedig másnap elfogta a csendörség. ${ }^{173}$

A néhány órával később a körzetben ledobott 11 fös HANKÓ szovjet ejtőernyös partizán osztag Borsodnádasdtól délre (Ózd D $15 \mathrm{~km}$ ) ért földet. Az osztag feladatai közé tartozott, hogy próbálja felvenni a kapcsolatot az 1944. IX. 7-én bevetett KUZNYEC szovjet ejtőernyős partizán osztaggal, amelyet 
azonban ekkorra már felszámoltak. Az újonnan érkezett osztag további feladatául szabták, hogy robbantásos akciókat hajtson végre Ózd és Diósgyőr térségében. Az elképzelés az volt, hogy ha a partizánok váltogatják a tevékenységük helyszínét, hol a Bükk nyugati, hol a keleti oldalán csapnak le, az megnehezítheti a magyar hatóságok eredményes fellépését. Mindkét érkező osztag utasítást kapott, hogy a helyi lakosok, bányászok, vasgyári munkások közül toborozzon csatlakozókat, és építsen ki egy további csoportok fogadására is alkalmas nagyobb partizánbázist a Bükk hegységben. A borsodnádasdi csendör őrs, lakossági bejelentések segítségével sikeresen felderítette a partizánok tartózkodási helyét, és a kirendelt honvéd karhatalommal együttműködve két nap alatt felszámolták az ejtőernyős osztagot. A partizánok közül négy főt megöltek, négy fö fogságba esett. Három ejtőernyősnek sikerült elmenekülni, és hetekig bujkáltak Fedémes térségében,1944. X. 15-én azonban a csendőrség elfogta őket is. ${ }^{174}$

1944. IX. 12-én a PUT vezetése úgy döntött, hogy felállítanak egy olyan szovjet ejtőernyős partizán osztagot, amely a magyarországi gerillaharcot fogja szervezi. Mivel azonban az ország északi részében ledobott osztagok nem tudtak megkapaszkodni, mert azokat a magyar rendvédelmi szervezetek felszámolták, az irányítást a magyar határtól távolabb, a szlovák felkelők által ellenőrzött területre kívánták áthelyezni. A biztonságos megérkezés és a sorok rendezése után az osztagoknak a földön kellett eljutni Magyarország területére, és egy központi bázist kialakítani Salgótarján és Ózd térségében. A feladatra a szvjatosinoi táborban 17 fö orosz és 20 fő magyar partizánt választottak ki. A KoZLOV szovjet ejtöernyös partizán osztag bevetésre 1944. IX. 19-én került sor. ${ }^{175}$

Az első gép 18 órakor szállt fel Kijevből, a fedélzetén kilenc szovjet ejtőernyőssel ${ }^{176}$ és probléma nélkül megérkezett a Zólyom közelében, a várostól 7 km-re, északra fekvő Tri Duby repterére. Fél órával később indult Kijevből a második gép, 10 magyar és öt szovjet partizánnal. ${ }^{177}$ A második gép Besztercebánya térségében, a várostól $10 \mathrm{~km}$-re, északnyugatra lévő Kordéfalva község mellett dobta le az ejtőernyősöket. A földet érést kisebb zúzódásokkal mindenki megúszta. Gyorsan megtalálták egymást, hajnalban már csak egyikőjük hiányzott, de délig előkerült ő is. Rövid pihenő után déli irányba indultak, és 1944. IX. 21-én Zólyomban egyesült az osztag első részével. Az osztag további 10 magyar tagját, valamint egy szovjet rádióst 1944. IX. 21-én indították útnak. ${ }^{178}$ A pilóták azonban a rossz idő miatt nem találták meg a célterületet, így hat órás út után az ejtőernyősöket visszavitték Kijevbe. Néhány nappal később áthelyezték őket a 4. Ukrán Front hatáskörébe, és a fronthoz közelebb eső Sztanyiszlau melletti opresovcei bázisra vitték az osztag ezen részét, végül azonban nem kerültek bevetésre. ${ }^{179}$

1944. IX. 22-én Zólyomban KozLOV szovjet ejtőernyős partizán osztaghoz csatlakozó orosz, szlovák és magyar partizánok bevonásával — magukat magasabb egységnek tekintve - felállították a törzset, melynek az alárendeltségében két akciócsoportot hoztak létre. Ezt követően az egyik csoport Salgótarján felé indult útnak. Kezdetben jól haladtak, de néhány napon belül elfogyott az élelmiszer, és a választott útvonal is nehéz hegyes terepen vezetett át. A magyar határt Losonc és Rimaszombat között lépték át, Pinc-Kétkeresztúr térségében és 1944. IX. 28-án megérkeztek Gömörsid községhez (Fülek K 5 km). Létszámuk ekkor már közel 60 fö volt. Azonnal akcióba kezdtek. 1944. IX. 29-én Csomatelke térségében az akciócsoport tagjai elfogták az ajnácskői csendőr őrs két fős járőrét. Hosszabb vita után úgy döntöttek, hogy a lefegyverzett csendöröket elengedik. Ezzel akartak bizalmat kelteni a lakosságban, és cáfolni a szovjet partizánok erőszakosságáról terjengő híreket. ${ }^{\mathbf{1 8 0}}$

A döntően magyarokból álló akciócsoport Sőreg-Óbást felé folytatta az útját. Ott azonban két honvéd század, a VII. csendőr kerület salgótarjáni tanszázadának második szakasza, továbbá a helyi csendőr őrsök járőrei, valamint az ejtőernyős-elhárító szolgálat tagjai állták útjukat. Az első összecsapás után az akciócsoport visszafordult és észak felé, Ajnácskő irányában igyekezett kitérni az üldözők elől, azok azonban folyamatosan a nyomában voltak. Ezért a partizánok Guszona-Poltár irányában elhagyták az országot. A partizánok azt jelentették Kijevnek, hogy Magyarország belsejében jelenleg nem lehet nagyobb szabású partizán tevékenységet folytatni, mert az elérhető eredmény nem lenne arányban a várható áldozatokkal. A PUT úgy döntött, hogy a térségben müködő szovjet ejtőernyős osztagok irányítására hivatott törzsek és osztagaik egyelöre a biztonságosabb szlovák területen létesítsenek bázist, és onnan hajtsanak végre akciókat magyar célpontok ellen, elsősorban Rimaszombat, Tornaalja, és Rozsnyó térségében. ${ }^{181}$

Ennek nyomán, 1944. X. 2-án a KozLOV szovjet ejtőernyős partizán osztag döntően magyar tagokól álló akciócsoportja - egyeztetve az osztag-parancsnoksággal — Babarét (Rimaszombat É $15 \mathrm{~km}$ ) mellett állította fel a táborát, és onnan indult a magyarországi bevetésekre. Az osztag kisebb rajtaütéseket hajtott végre a Losonc és Rozsnyó közötti közúti és vasúti forgalom, néhány kisebb bányatelep és katonai raktár ellen. Az akciócsoport egy robbantó különítménye Balogfalva térségében (Rimaszombat DDK 10-15 km) aláaknázta a Fülek-Miskolc vasútvonalat. A robbanás nyomán kisiklott egy német hadianyagot szállító szerelvény. A pályaszakasz helyreállítása két napig tartott. ${ }^{182} \mathrm{Az}$ akciócsoport 
vezetője megkísérelte átállásra bírni, a németek elleni harcra rávenni, de legalábbis passzivításra ösztönözni a rimaszombati helyőrséget. 1944. X. 12-én felvette a kapcsolatot a Felsö- és Alsópokorágy közötti határvadász őrssel. Kérésére az őrs-parancsnok telefonált Rimaszombatba, a helyőrség parancsnokának, hogy egy partizán-parancsnok tárgyalni kívánna vele. A helyőrség parancsnoka közölte vele, hogy hajlandó a megbeszélésre és kimegy a határvadász őrsre. Fél órával később azonban egy század honvéddel érkezett meg, hogy a partizánokat elfogják. A kirobbanó tüzharcban egy fö honvéd elesett, egy fö pedig megsebesült. Súlyos sebet kapott a partizán akciócsoport vezetőjének egyik kísérője is, aki fogságba esett. Az akciócsoport vezetője pedig másik két emberével elmenekült. ${ }^{183}$

1944. X. 15-én a Jolsva-Pelsőc vasútvonalon, Jolsvatapolca közelében a KOZLOV szovjet ejtőernyös partizán osztag döntően magyar tagokól álló akciócsoportja felrobbantott egy vasúti hidat. A forgalom 30 órán át szünetelt. 1944. X. 17-én az akciócsoport egy része a németek nyomása elől északnyugat felé vonult vissza, Babarétről a 13 km-re fekvő Klenócba. Az akciócsoport másik része északkelet felé, Gömörrákos irányába indult. Végül Nagyrőce (Jolsva ÉNY $10 \mathrm{~km}$ ) térségében találkoztak ismét. A Jolsva felől támadó németek elől az akcicsoport tovább vonult északkelet felé, Szabados határába. 1944. X. 19-én hat felderítőjük Szabados községnél járt (Nagyrőce KÉK $10 \mathrm{~km}$ ), hogy új táborhelyet keressen. A település közelében megtámadtak egy kisebb német lovas egységet. A heves tủzben és kézigránát robbanásban öt fö német katona meghalt. A partizánok két lovat és egy géppisztolyt zsákmányoltak. ${ }^{184}$

1944. X. 20-án az akciócsoport mintegy 40-50 tagja jelent meg Gömörnánás községben (Jolsva DK $8 \mathrm{~km}$ ) ahol kocsit, lovat, élelmiszert raboltak és két civilt magukkal vittek. Az eset nyomán a jolsvai csendör örs, a határvadász örs és magyar illetve német katonai alakulat közremüködésével üldözőbe vette az észak felé vonuló partizánokat. Amikor rajtuk ütöttek, rövid tüzharc bontakozott ki, melyben öt fö partizán meghalt, 23 föt elfogtak, a többiek elmenekültek. A másik oldalon egy fő határvadász elesett, egy fő csendör pedig megsebesült. 1944. X. 20-án este partizánok törtek be Jolsvára. A helyi csendör őrs 11 fő csendőre, illetve a településen tartózkodó honvéd járőr felvette velük a harcot. A 35-40 fös, túlerőben lévő partizánok leküzdésére a környező településekről újabb csendőrök és határvadászok érkeztek. A tüzharc a község körül még másnap is tartott. ${ }^{\mathbf{1 8 5}}$

KoZLOV szovjet ejtőernyős partizán osztag egy kisebb robbantó egysége, 1944. X. 20-án Fülek és Gömörsid között felrobbantottak egy vasúti átereszt. A forgalom egy napig állt ezen a szakaszon. 1944. X. 25-én egy 20 fös különítmény lesben állt az Alsósajó-Csetnek úton, és Pétermány térségében rajta ütött egy szekeres német utászegységen. A tủzharcban nyolc fö németet megöltek 12 föt megsebesítettek, a többiek szétfutottak. A zsákmányt azonban nem tudták összeszedni, mert egy nagyobb német alakulat közeledett. 1944. XI. 6-án az osztag egyik akciócsoportja Kisgencs falu közelében (Csetnek K $3 \mathrm{~km}$ ) elfogott egy motorkerékpáros német híradó rajt, amely a partizánok által korábban megrongált telefonvezetékeket ellenőrizte. A zsákmány egy motorkerékpár, egy géppisztoly és két puska volt. ${ }^{186}$

Időközben a KOZLOV szovjet ejtöernyös partizán osztag mindkét akciócsoportja nevet választott magának. Az orosz-szlovák akciócsoport a „hazáért”, a magyar akciócsoport pedig a „Petőfi Sándor” nevet vette föl. A magyar akciócsoport ekkor már közel 100 föt számlált. 1944. XI. 9-én egy harmadik akciócsoport is felállításra került, amelynek a „Sztálin” nevet adták. A harmadik akciócsoport bázisát Tiszolc térségében (Rimaszombat É $45 \mathrm{~km}$ ) volt. 1944. XI. 17-én a KozLOV szovjet ejtöernyös partizán osztag - felsőbb parancsnokság javaslata nyomán — felvette a „Rákosi Mátyás dandár” nevet. Ennek nyilvánvaló politikai és propaganda okai voltak, hogy a magyar kommunista vezetés ilyen módon képviseltethesse magát a fasiszta erők elleni harcban és győzelemben. A KozLOV szovjet ejtőernyős partizán osztag összlétszáma ekkor 536 fő volt, közte mintegy 250 magyar származású partizánnal. A „Petőfi Sándor" akciócsoport szintén 250 fö körüli létszámmal rendelkezett, sok — eredetileg más szlovák partizán osztagban harcoló — magyar is átkérte magát a „Petőfi Sándor” akciócsoportba. ${ }^{187}$

1944. XII. 13-án a Szabados térségében működő partizánbázis felderítésére három német páncélautó érkezett Csetnekről Mártonházára. A felderítő németeket a partizánok megtámadták, egy páncélgépkocsit kilőttek, két fó német meghalt, egy fö megsebesült, a többiek visszavonultak. 1944. XI. 25-én a partizánok aláaknázták a Rozsnyó-Torna mủutat, Krasznahorkaváralja községtől nyugatra, 2 km-re. Egy német teherautó oszlop első gépkocsija ráhajtott az aknára. A robbanásban a gépjármü felgyulladt és kiégett, öt fö német meghalt, hét fö megsebesült. 1944. XI. 25-én a KozLOV szovjet ejtőernyős partizán osztag magyar akciócsoportjának különítmény a Mártonháza mellett rajtaütött egy vasúti kézihajtányon. Megöltek három fő német katonát, egy géppuskát és egy puskát zsákmányoltak. ${ }^{188}$

1944. XI. 28-án a térségben lévő német erők nagyobb szabású akciót indítottak a KozLOV szovjet ejtőernyős partizán osztag magyar akciócsoportja szabadosi bázisának felszámolására, ahol mintegy 250 partizán tartózkodott. Nagyrőcére 400, Csetnekbe 300, Alsósajóra 350 német katona érkezett. Magyar részről készültségbe helyezték a Rozsnyó és Jolsva közötti határvadász alakulatokat és a csendőr 
örsöket, hogy a partizánok déli irányban ne térhessenek ki a három irányból támadó németek elöl. A partizánok heves harcok között keleti irányban törtek ki a bekerítésböl, és 30 km-t megtéve Henclófalva térségében (Rozsnyó ÉÉK $20 \mathrm{~km}$ ) alakítottak ki új tábort. Az összecsapásokban több partizán elesett, köztük az akciócsoport parancsnoka is. Ezt követően az akciócsoport kettévált, az egyik részük Henclófalván maradt, a másik pedig délkeleti irányba vonult tovább, Kassa körzetébe. ${ }^{189}$

1944. XI. 30-án a Rozsnyórudna (Rozsnyó ÉNY 4 km) térségében lévő erdőkben a rozsnyói csendőr őrs nyolc csendőrével megerősített honvéd szakasz kutatott a partizánok után. A keresőcsoport összetüzésbe került a KOZLOV szovjet ejtöernyös partizán osztag magyar akciócsoportjának egyik 40 fös különítményével. A partizánok automata fegyvereikkel visszavonulásra késztették a honvédekből és csendőrökből álló alakulatot, melynek vesztesége a partizánok adatai szerint kilenc fö halott és hét fő sebesült volt, míg a partizánoknál csak két fő sebesülés történt. A KozLOV szovjet ejtőernyős partizán osztag magyar akciócsoportjának másik különítménye Szomolnok közelében egy német alakulatba ütközött. Rövid tủzharc után, melyben egy fö német elesett, a partizánok déli irányban kitértek. Ájfalucskában lefegyverezték a magyar határvadász örsöt, de a legénységet elengedték, néhány határvadász azonban csatlakozott a partizánokhoz. Rudnokfürdő közelében elfogtak két fö SS katonát, akiket megöltek. 1944. XII. 2-án, ez a különítmény erődítést építő müszaki egységen ütött rajta Szomolnoktól délnyugatra, 7 km-re. A harcban egy fö honvéd meghalt, két fö pedig megsebesült és a partizánok közül is meghalt két fö. ${ }^{190}$

A KOZLOV szovjet ejtőernyös partizán osztag magyar akciócsoportjának kitörése után a németek további erőket, gyalogságot és tüzérséget vonultattak fel a KozLOV szovjet ejtöernyős partizán osztag ellen a Dobsina-Csetnek-Jolsva-Nagyröce vonal mentén bekerítve a partizánokat. A német csapatok mellett nagyobb számban vetettek be vlaszovista (német oldalon harcoló orosz) erőket is. 1944. XII. 5én reggel indult az összpontosított támadás. Igyekeztek elfoglalni a partizánok táborhelyeit, felgyújtottak minden épületet a hegyekben, ami télvíz idején menedéket jelenthetett a számukra. A vlaszovisták élve a nyelvi tudásukkal sokszor vegyes öltözetủ, polgári-katonai ruhás álpartizánként jelentek meg, így könnyen szerezhettek információkat, csatlakoztak kisebb ellenálló csoportokhoz, vagy be tudtak jutni a táboraikba. KoZLOV szovjet ejtőernyős partizán osztag már az első napokban komoly veszteségeket szenvedett. A partizánok igyekeztek kitörni a bekerítésböl, először északra indultak, majd Sajóréde elkerülésével keletre fordulva Rozsnyótól északra, Henckófalva közelében építettek ki új bázist. ${ }^{191}$

A németek azonban több alkalommal is kutatóakciókat indítottak a térség erdőségeiben a partizánok ellen. 1944. XII. 7-én a KOZLOV szovjet ejtöernyős partizán osztag magyar akciócsoportjának egyik különítményét váratlan német támadás érte. A partizánok közül három fő elesett, négy főt sebesülten elfogtak, köztük a különítmény parancsnokát is, akit 1944. XII. 20-án Dobsinán kivégeztek. Ezt követően a KOZLOV szovjet ejtőernyős partizán osztag magyar akciócsoportjának két különítménye újra egyesült és Aranyida (Kassa NYÉNY $18 \mathrm{~km}$ ) térségében rendezkedett be. Az onnan északra elterülő területet NYEVSZKIJ szovjet ejtőernyös partizán osztag ellenőrizte. 1944. XII. 22-én Rudnoknál (Jászó K 3 km) a partizánok garázdálkodó nyilasokon ütöttek rajta. Egy fő saját halott mellett 15 fő nyilast megöltek, 39 föt elfogtak. A magyar akciócsoport 1945. I. 5-én találkozott a szovjet csapatokkal. A létszám ekkor már 272 fö volt, amelyből 166 volt magyar. A követően a KozLOV szovjet ejtöernyös partizán osztag másik akciócsoportjában harcoló magyar különítmény 1944. XII. 21-én Rozsnyótól északra foglyul ejtette egy tüzérségi figyelőpont teljes személyzetét. Tíz nappal később a különítmény benyomult Csucsom községbe (Rozsnyó É $5 \mathrm{~km}$ ) és puskalövés nélkül elfogott és lefegyverzett 102 magyar honvédet. Néhány nappal később a Vörös Hadsereg elérte ezt a térséget. ${ }^{192}$

A harcok befejezésekor a KozLOV szovjet ejtőernyős partizán osztag („Rákosi dandár”) 483 fővel rendelkezett, ezen belül a magyar különítmény („Petődi Sándor osztag”) 274 fővel. a A KozLOV szovjet ejtöernyös partizán osztag számolója szerint a négy és fél hónap alatt elpusztítottak, megsebesítettek 1488 fö ellenséget. Felégetettek egy lőszer- és két élelmiszer raktárt, megsemmisítettek, illetve megrongáltak 18 közúti és négy vasúti hidat, átereszt, öt mozdonyt, 76 vagont, egy vasúti hajtányt, egy személy- és 16 gépkocsit, egy páncélautót, három motorkerékpárt, hat aknavetőt, nyolc géppuskát. Zsákmányuk egy aknavető, 28 géppuska és golyószóró, 58 géppisztoly, 367 puska, három páncéltörő puska, 40 pisztoly, 1150 kézigránát, 8700 töltény, 15 szekér és 40 ló volt. Ezen belül az akciócsoport müködésének eredménye 942 fö ellenség megölése, megsebesítése, egy löszerszállító vonat és hat teherautó megsemmisítése volt. A partizánok 18 géppuskát és golyószórót, 24 géppisztolyt, 196 puskát zsákmányoltak. A harcok során a dandár személyi állományából (az ejtőernyősök közül) 16 fő elesett, 13 fő eltünt, 24 fő megsebesült. ${ }^{193}$

Még 1944 augusztus végén a PUT által partizántanfolyamon kiképzett katonák közül mintegy 40 föt átadtak az 1. Ukrán Front Haditanácsa mellett müködő Partizán Törzsnek. Az ejtőernyősöket a Lvov 
melletti derevaci táborba szállították, hogy Kelet-Szlovákiában kerüljenek bevetésre, a szlovák nemzeti felkelés, illetve a Kárpátok-Dukla szovjet hadművelet támogatására. Egy magyarokból álló egységet azonban a 4. Ukrán Front kérésére 1944. IX. 18-án Sztanyiszlavba vezényelték át, és észak-magyarországi bevetésre készítették fel. ${ }^{194}$ A tervek szerint Putnok térségében (Ózd ÉK $15 \mathrm{~km}$ ) dobták volna le őket, ahonnan Ózd és Diósgyőr egyaránt jól elérhető. Az 1944. IX. 19-ei bevetés során azonban a szállítógép a front felett heves légvédelmi tüzet kapott, találat érte, ezért az ejtőernyősöket $100 \mathrm{~km}$-rel a célterület elött, Nagykázmér-Biste (Sátoraljaújhely ÉÉNY $18 \mathrm{~km}$ ) körzetében dobták le. A földet éréskor többen megsérültek, egyikőjük mindkét lába eltört. Társai fél napig cipelték, majd egy rejtekhelyet kerestek a számára és otthagyták. Egy másik partizán szintén mozgásképtelenné vált, Alsómihályi határában landolt, és combnyaktörést szenvedett. A gépröl négy ejtőernyős zsákot dobtak le, amiben fegyver, löszer, élelem és tartalék felszerelés volt. Ezeket a nagy súly miatt egyelőre elásták, hogy majd később visszatérhessenek értük. Megpróbáltak rádión érintkezésbe lépni a parancsnoksággal, de ez nem sikerültt. ${ }^{195}$

Az ejtőernyősök leszállását azonnal felfedezték, a kassai és az ungvári csendőr nyomozó alosztály már éjfél körül jelentést kapott a partizánok érkezéséröl. Hajnalban a környékbeli csendör őrsök sürü járőrözésbe kezdtek a felkutatásukra. A keresésben az alsómihályi, az eszkárosi, a pálházai őrs 31 csendőre vett részt, valamint a kassai csendőr szárny egy szakasza. A leszállási terület lezárására mozgósították a helyi ejtőernyős-elhárító szolgálatot. 1944. IX. 20-án elfogták a földet éréskor mindkét lábát eltörő járásképtelen és az ugyancsak mozgásképtelen és eszméletlen partizánokat. 1944. IX. 21-én bekerítették a partizánokat és támadást indítottak ellenük. Két fö partizán már az összecsapás elején kézigránát találattól elesett, másik két fö partizánt pedig tüzharcban lelőttek. Egy fö partizánnak ugyan sikerült elmenekülnie, de néhány órával később az alsómihályi csendőr őrs egy járőre elfogta. A többi partizán az osztag-parancsnok vezetésével kijutott a gyürüből, és nyugati irányba haladva kíséreltek megbiztonságos helyet keresni a Zempléni hegységben. 1944. IX. 23-án azonban Telkibánya határában a gönci csendőrőrs járőre elfogta őket. Elöbb Ungvárra vitték a partizánokat, a 8/1. nyomozó alosztályra, majd Budapestre szállították a foglyokat. ${ }^{196}$

1944 szeptember közepén a szlovák felkelés által támogatott partizáncsoportok élénk tevékenységet fejtettek ki a felvidék középső régiójában, Balassagyarmat és Kassa között. A PUT 1944. IX. 15-én utasítást adott a magyarországi partizánmozgalom kifejlesztése érdekében osztagok kiküldésére a magyar határra. Egy héttel később a partizánok parancsnoka jelentette, hogy intézkedett az ügyben, Losonc körzetébe egy 40 fös osztagot irányítottak, és létrehoztak egy többségében magyarokból álló akciócsoportot, amely Rozsnyó térségében tevékenykedik. 1944. IX. 18-án Kassától északnyugatra, 15 km-re a partizánok megtámadták az aranyidai határvadász őrs két fős járőrét. A katonákat lefegyverezték és elhurcolták. 1944. IX. 20-án ugyanezen partizánok mintegy 60-70 fővel ismét megjelentek ezen a területen. A jászói csendőr őrs és a kivezényelt határvadászok tüzharcban megállították a fegyveres csoportot, és visszaszorították szlovák területre. A partizánok két fö halottat vesztettek, és több sebesülés is történt mindkét oldalon. 1944. IX. 23-án a partizánok újra felbukkantak. Megszállták Jászómindszentet, elvágták a telefonvonalakat, elhurcolták a községi bírót, élelmiszert és ruhát raboltak. A jászói csendőr őrs, a határvadászok és a Kassáról kivezényelt honvéd szakasz tüzharcban kiszorította a partizánokat a községből, és a szlovák határig üldözte őket. ${ }^{197}$

Losonc térségében is folytak az összecsapások. 1944. IX. 19-én a szlovák partizánok egy csoportja Pöstyénpusztánál (Szécsény ÉÉNY $5 \mathrm{~km}$ ) felrobbantotta az Ipolyon átvezető híd északi hídföjét. A forgalom másfél napig szünetelt. Másnap attól a helytől északra, $10 \mathrm{~km}$-re robbantást hajtottak végre a Losonc-Balassagyarmat közötti vasútvonalon. Az aknák egy német szerelvény alatt robbantak, egy fö német katona meghalt, 10 fő megsebesült. Megrongálódott 10 tehervagon, elpusztult 32 ló. A vasúti töltés és sínpálya helyreállítása 35 órát vett igénybe. ${ }^{198} 1944$. IX. 24-én hat fő partizán jelent meg Gömörnánás határában (Pelsőc ÉNY 7 km), feltartóztattak és elraboltak egy lovas kocsit. A helyi csendőrség a határvadászok és a határ menti rendőri kirendeltség járőrei a partizánok keresésére indultak. Elöször a rendőrjárör érte utol őket, a kibontakozó tüzharcban egy fö rendőr meghalt, egy fö pedig megsebesült. Miután a csendőrök és a határvadászok is a helyszínre értek, a partizánok észak felé elmenekültek. 1944. IX. 25-én Pelsőc közelében a partizánok felrobbantottak egy vasúti hidat. A forgalom a helyreállítások idején, másfél napig szünetelt. 1944. IX. 26-án Losonc és Rimaszombat között Kétkeresztúrnál 30 fős partizáncsoport megtámadta a helyi határvadász őrsöt. A katonák felvették a harcot, és hamarosan a helyszínre érkezett az osgyáni csendőr őrs megerősített járöre és a rimaszombati határvadászportyázó század egy szakasza. Ezt látva a partizánok elmenekültek. ${ }^{199}$

1944. IX. 25-én Királyhelmec közelében a 11 fös POLJANYIN szovjet ejtöernyös partizán osztag szállt le. Az előző napok partizánok elleni akciói miatt a helyi csendőrség, az ejtőernyős-elhárítás és a honvéd karhatalom még riadókészültségben volt. A partizánokat már a földet éréskor felfedezték, és 
azonnal támadás indult ellenük. A következő két nap összecsapásai során három fő ejtőernyős elesett, öt föt elfogtak a hatóságok, csak három főnek sikerült elmenekülnie a Latorica erdőségeiben. ${ }^{200}$

1944. IX. 27-én éjszaka újabb ejtőernyős akcióra került sor a Felvidéken. Szepesremete határában (Rozsnyó ÉK $30 \mathrm{~km}$ ) a „Scsorsz” elnevezésü LOGVINYENKO szovjet ejtőernyös partizán osztag ereszkedett le. Az osztag oroszokból és szlovákokból állt, magyar tagja nem volt. Müködési körzeteként számukra Rozsnyó-Ózd-Eger-Miskolc térségét jelölték meg. A csoportot a földet érés után a MARTINOV szovjet ejtőernyős partizán osztag összekötői várták és biztonságos táborhelyre kísérték. ${ }^{201}$

Az osztag első akcióit Rozsnyó térségében hajtotta végre, amikor robbantást valósítottak meg $\mathrm{Fe}$ renctelep-Luciabánya térségében (Rozsnyó K $30 \mathrm{~km}$ ), a Jászó és Mecenzéf között futó vasúti mellékvonalon. A robbantás során egy fö orosz ejtőernyős partizán életét vesztette, akit hátrahagytak. Ugyanezen a napon Losonctól délnyugatra, $20 \mathrm{~km}$-re, Litke és Rárósmulyad között a partizánok megtámadták a határvadász járőrt. A határvadászok viszonozták a tüzet, mire a partizánok visszavonultak. Másnap ismét megjelentek a partizánok Rárósmulyad térségében és lelőttek egy erdőőrt, aki nem akarta tovább kalauzolni őket. 1944. X. 10-én hajnalban mintegy 20-25 partizán megpróbált aknát telepíteni a Sajóháza (Rozsnyó É $3 \mathrm{~km}$ ) melletti vasúti hídra. Az őrség azonban felfedezte őket és tüzet nyitott rájuk. A hamarosan megérkező erősítés miatt a partizánok visszahúzódtak az erdőbe. ${ }^{\mathbf{2 0 2}}$

LOGVINYENKO szovjet ejtöernyős partizán osztag létszáma gyorsan gyarapodott. Nagy számban léptek be a németek által szétszórt partizáncsoportok tagjai, szlovák katonaszökevények, szökött szovjet hadifoglyok. Mivel az osztag a müködését Észak-Magyarországra is kiterjesztette, sokan jelentkeztek a felvidéki magyarok közül is a „Scsorsz” osztagba. 1944. X. 10-én az osztag 82, 1944. X. 20-án pedig már 128 fegyveresből állt, és több mint száz civil, szimpatizáns, összekötő segítette a tevékenységét. Az osztag két akciócsoportra (amelyet századnak neveztek), akciócsoportonként pedig kettö-négy különítményre (amit szakasznak neveztek), különítményenként 20-30 fővel tagolódott. 1944. XI. 15-én az 1. különítmény 97 fớből (jelentős számban magyarokból) álltt. ${ }^{203}$ A második küólönítmény 136 főből állt, az első különítmény 1944. XI. 15-én a „Vörös János”, a második különítmény pedig a „Szabad Szlovákiáért" nevet vette fel. ${ }^{204}$

1944. XII. 1-jén az első akciócsoport nyugatra indult és a Rimaszombat-Salgótarján-Ózd által határolt területen fejtett ki tevékenységet. A második akciócsoport Dobsina-Nagyröce-Rozsnyó térségében müködött. A magyar területen folytatott tevékenységet végig nehezítette, hogy a lakosság itt nem támogatta a partizánokat úgy, mint a szlovák vagy ruszin lakta vidékeken. A LOGVINYENKO szovjet ejtőernyös partizán osztag 1945. I. 25-én találkozott a Vörös Hadsereggel. Létszáma ekkor 414 fö volt, köztük 148 magyar. A harcok befejezése után a magyar partizánok többségét Debrecenbe küldték, ahol az Ideiglenes Kormány irányítása alá kerültek. ${ }^{205}$

1944. X. 7-én a 4. Ukrán Front Haditanácsa mellett müködő Partizán Törzs a nyolc fös ÖRLEY szovjet ejtöernyős partizán osztagot vetette be a Börzsönyben szervezési feladatokkal. ${ }^{206} \mathrm{~A}$ ledobás helyszínének Diósjenő körzetét (Vác É $20 \mathrm{~km}$ ) választották. A csoport 22 órakor szállt fel Sztanyiszlauból. Az ejtőernyősök Diósjenő közvetlen közelében értek földet, így már a leszállás pillanatában felfedezték őket. A leszállási körzet lezárására és a partizánok felkutatására kivezényelték az esztergomi helyőrség egy századát, a Rétság térségében állomásozó $1 /$ III. páncélos pótzászlóalj egy századát, valamint a térségben tartózkodó, feltöltés alatt álló német alakulatot, továbbá a VII. csendör kerület balassagyarmati szárnyának több őrsét. Kelet felől Nógrádverőce, Rétság, Nagyoroszi, Diósjenő 44 csendőre, nyugatról pedig Ipolyvisk, Ipolyszakállos, Ipolypásztó, Ipolyság 41 csendőre közelített a partizánokhoz. Bár a Börzsöny nyújtott némi természetes védelmet a partizánoknak, de az üldözők így is hamarosan nyomukra bukkantak. A Csarna-patak völgyében katonai és csendőr járőr, valamint az ejtőernyős-elhárító szolgálat tagjai, erdészek és leventék kerítették be az ejtőernyősöket. A kialakuló tüzharcban egy fő partizán meghalt, egy föt pedig elfogtak. Ugyanakkor egy levente is életét vesztette. A partizánok a sürübb erdőségben kerestek menedéket. ${ }^{207}$

Egyre komolyabb problémát okozott nekik az élelem hiánya. 1944. X. 12-én légi ellátmányt kaptak, de a ledobott négy ejtőernyős zsákból csak kettőt találtak meg, ezekben lőszer és robbanóanyag volt, élelem vagy meleg ruha viszont nem. 1944. X. 14-én az osztag két tagja élelmiszer beszerzésére indult, de nem tértek vissza. Két nappal később a partizánok elfogására kirendelt erők egy erdészháznál két fegyveres férfit bekerítettek. Megadásra szólították fel őket, de nem jöttek ki. A támadás során az épület tüzet fogott és teljesen kiégett, a partizánok a romok között vesztették életüket. 1944. X. 20-án a khonvédség és csendőrség ráakadt az osztag megmarat embereinek nyomára, akik rövid ellenállás után megadták magukat. A foglyokat először Kóspallagra, Szobra, majd Rétságra vitték. 1944. X. 24-én Budapestre, a Hadik laktanyába szállították, kihallgatásra. 1944. XI. 8-án átkerültek a Margit körúti fogházba, majd 1944. XI. 12-én a Komáromi Csillagerődbe vitték öket. Közülük két föt a német ekvették át és 
Németországba szállították. Az osztag vezetőjét és egy másik tagját más komáromi foglyokkal együtt 1944 november végén gyalogmenetben osztrák területek felé indították. A két partizán azonban Tany községnél megszökött. ${ }^{208}$

1944 szeptember-november folyamán, magyar területen további partizán osztagok is müködtek. 1944. X. 13-án, Sárospatak-Erdőbénye térségében szállt le a négy fös KUNDRESOV szovjet ejtőernyös partizán osztag, akiket a Vörös Hadsereg Főparancsnoksága alá tartozó „62. számú törzs” indított útnak. Feladatuk elsősorban felderítés volt, ezen kívül agitációt kellett folytatniuk, és megpróbálni nagyobb létszámú partizán osztagokat létrehozni. A magyar kommunista vezetés összekötőket ígért az ejtőernyősök számára, akiknek várniuk kellett volna őket. A partizánokat azonban senki sem várta. Vagy a Moszkvából küldött üzenet nem jutott el a körzetben müködö illegális csoporthoz, vagy a rendvédelmi erök határozott fellépése riasztotta el az összekötőket, hogy felvegyék a kapcsolatot a leszálló ejtőernyősökkel. ${ }^{209}$

Az osztag két hétig rejtőzött, a csendőrségnek azonban sikerült a nyomukra jutni. 1944. X. 28-án az erdőbényei csendőr őrs járőre, az ejtőernyős-elhárító szolgálat egységeivel közösen megtalálta és megtámadta öket. A tủzharcban egy fő partizán sebesülten fogságba esett, a többiek elmenekültek. Másnap a helyi erdész felfedezte a partizánok táborhelyét és jelentette a csendőrségnek. A csendőrök hajnalban ütöttek rajta az Erdőbénye határában, a településtől 4-5 km-re, egy tanyán pihenő ejtőernyősökön, és mindhármukat elfogták. A foglyok először Kassára kerültek a 7. csendőr nyomozó alosztályhoz, onnan Budapestre, a Margit-körúti fogházba, majd Sopronkőhidára, végül pedig Németországba szállították őket. ${ }^{210}$

1944. X. 19-én vetette be a 4. Ukrán Front Haditanácsa mellett müködő Partizán Törzs a négy fős BONDARENKO szovjet ejtőernyös partizán osztagot Szendrö (Miskolc É $30 \mathrm{~km}$ ) térségében azzal az elsődleges feladattal, hogy a Miskolc-Kassa körzetében folytasson felderítést, illetve teremtsen kapcsolatot a helyi lakossággal a szovjetbarát személyek felderítése céljából, akikre a Vörös Hadsereg megérkezése után építeni lehet. Ugyancsak a 4. Ukrán Front Haditanácsa mellett müködö Partizánmozgalom Törzse indította útnak 1944. X. 25-én a négy fös MIRONOV szovjet ejtöernyös partizán osztagot, akik Felsőpalojta-Nagykürtös térségében (Balassagyarmat É 20-25 km). Az osztag feladata volt hogy információkkal lássa el a szovjet csapatokat és propaganda tevékenységet végezzen a szlovák és magyar lakosság körében. A partizánok támogatása miatt a HLINKA-gárdisták 1944. XII. 18-án Korpona közelében 13 fő magyar és szlovák embert végeztek ki. ${ }^{211}$

Ipolyság-Balassagyarmat térségében harcolt egy szlovák partizán osztag, melyet még 1944 augusztus végén dobtak le Lest-Nagylám körzetében (Losonc NY 25 km). Az osztag 1944 szeptemberben szlovák területen tevékenykedett, 1944 októberben húzódott le a magyar határra. 1944. X. 15-én 19 órakor 30-35 partizán megtámadta az Egeg községben (Ipolyság ÉÉNY $15 \mathrm{~km}$ ) lévő határvadász őrsöt. Először elfogták a falu közelében az őrs három fős járőrét, majd behatolva a településre a laktanyaépület ellen intéztek támadást. A határvadászok felvették a harcot, és hamarosan megérkezett a deméndi csendőr őrs nyolc fős erősítése is. A partizánok kénytelenek voltak visszavonulni, a foglyokat elengedték. 1944. X. 17-én éjszaka a Balassagyarmat-Szécsény közötti vasútvonalon, Örhalomnál (Balassagyarmat K $8 \mathrm{~km}$ ) a partizánok aláaknázták a síneket. A szerkezet egy arra haladó szerelvény alatt robbant, a mozdony és a poggyászkocsi megrongálódott. A pályát reggelre helyreállították. ${ }^{\mathbf{2 1 2}}$

Miután a KOZLOV szovjet ejtőernyős partizán osztag kiépítése sikeresen megindult, Nógrádi Sándor, PUT és a szvjatosinoi partizánközpont magyar instruktora úgy döntött, hogy maga is bevetésre indul. Egyrészt úgy gondolta, hogy a Felvidék, a szlovák felkelés egyre szükülö, de még kitartó területe viszonylag biztonságos leszállásra kínál alkalmat, másrészt jó lehetőséget láttak abban, hogy a KOZLOV szovjet ejtőernyös partizán osztag és talán más, a térségben harcoló csoport tevékenységének koordinátoraként, a Magyarországot is érintő partizántevékenység egyik legfontosabb szereplője lehetnének. NÓGRÁDI Sándor 1944. X. 8-án három magyar összekötővel és két szovjet rádióssal érkezett meg Zólyomba, az ott illetékes szovjet partizán osztagokhoz. Nyilvánvalóan nem harci feladatokra, hanem egy nagyobb alakulat törzsének irányítására készültt. ${ }^{213}$

A leszállást követően NÓGRÁDI Sándor gyorsan berendezkedett, és nagyszabású szervezőmunkába kezdett. 1944. X. 11-én kérte, hogy a 4. Ukrán Front Haditanácsa mellett müködő Partizánmozgalom Törzse, amely átvette a magyarországi partizántevékenység feletti illetékességet, indítsa útnak a Felvidékre, a bevetésre korábban már felkészített magyar ejtőernyős osztagokat. Ugyancsak kérte, hogy a KozLOV szovjet ejtőernyős partizán osztag Kijevben maradt 10 főt számláló részét haladéktalanul küldjék el erősítésül. Sürgette, hogy a tervezett módon, Kárpátalján az USZTA szovjet ejtőernyös partizán osztag is kapjon újabb utánpótlást, dobják le hozzá a BUJANOV szovjet ejtőernyős partizán osztagot. A Partizánmozgalom Törzsének parancsoka azonban nemigen hagyta magát befolyásolni a frontvonal mögül intézkedő NóGRÁDI Sándortól. Közölte vele, hogy a CSATÁRI szovjet ejtöernyös partizán osztagot fegyelmi problémák miatt feloszlatták, a többieket a kedvezőtlen időjárás miatt egyelőre nem tudják 
bevetni, a BUJANOV szovjet ejtöernyös partizán osztag pedig nem az USZTA szovjet ejtöernyös partizán osztag, hanem a TKANKO szovjet ejtőernyős partizán osztag alezredes csoportjának megerösítésére szánják. NÓGRÁDI Sándor segítségképpen az elöljárójukhoz fordult, akinél elérte, hogy a PUT parancsnoka felsőbb utasítást kapjon a magyar osztagok bevetésére. ${ }^{214}$

Közben NÓGRÁDI Sándor áttette a székhelyét Divénybe (Losonc ÉNY $18 \mathrm{~km}$ ) a magyar határ közelébe és föként agitációs munkát végzett. Üzenetekkel, röplapokkal próbálta átállásra bíztatni a határvadász alakulatok személyi állományát, illetve helyi lakosokat igyekezett beszervezni felderítő és öszszekötő feladatra, akik segítségével kapcsolatot teremthetett a Salgótarján környéki munkásokkal. A szervezés mellett egyre csak sürgette a magyar csoportok ledobását, és jelentősebb mennyiségü hadianyag küldését kérte Babarét körzetébe (10 golyószóró, 20 géppisztoly, 40 puska, két páncéltörő puska, $300 \mathrm{~kg}$ robbanóanyag). Szorgalmazta, hogy dobjanak le négy fő rádióst, akik két külön tevékenykedő osztag kommunikációját is biztosíthatják. A PUT parancsnoka azonban közölte, hogy a jövőben minden kérést a 4. Ukrán Fronthoz kell intéznie. 1944. X. 17-én a 4. Ukrán Front illetékese azt az üzenetet küldte, hogy az utánpótlás már úton van, valójában azonban sem a csoportok, sem a rádiósok, sem a fegyverek nem érkeztek meg. 1944. X. 20-án NóGRÁDI Sándor türelmetlenül reklamált. Közölte, hogy pillanatnyilag mindössze 50 magyar partizán állt rendelkezésre a KOZLOV szovjet ejtőernyös partizán osztagban, ennél mindenképpen több ember kellett, ha magyar területen aktívabb müködést akartak kifejteni, ezért feltétlenül dobják le a többi magyar csoportot is. ${ }^{215}$

1944. X. 18-án szovjet katonai szállítógéppel Tri Dubyra érkezett NÓGRÁDI Sándor moszkvai öszszekötője, akit Besztercebányára vitték, ott találkozott NóGRÁDI Sándorral, onnan Divénybe irányították NÓGRÁDI Sándor bázisára. A közelben volt a VELICSKO szovjet ejtőernyös partizán osztag. Időközben azonban a németek és a szlovák hadsereg egyre szükebb területre szorította vissza a felkelőket. NóGRÁDI Sándor ezért kénytelen volt Divényböl visszatérni Zólyomba. A német elörenyomulás miatt azonban el kellett hagyniuk Zólyomot is, ezért 1944. X. 23-án Besztercebányára mentek. Másnap NóGRÁDI Sándor néhány fős utánpótlást kapott. Zólyomba érkezett TÖMPE András, ö lett a törzs politikai helyettese, álnéven ő lett a törzs politikai helyettese. ${ }^{216}$

NÓGRÁDI Sándor igyekezett több felkelöt maga köré gyüjteni, Besztercebányán már mintegy 60 fővel rendelkezett. Két, egyenként három fős felderítő csoportot indított útnak, annak tisztázására, hogy hogyan lehet viszonylag biztonságosan Magyarországra eljutni. A felderítők azonban németekbe ütköztek, csak egy fö tért vissza közülük. 1944. X. 25-én Besztercebányáról északi irányban Óhegyre mentek. Ott találkoztak a JEGOROV szovjet ejtóernyös partizán osztag törzsével, ahonnan az osztag-parancsnok NÓGRÁDI Sándor mellé rendelt. Korábban az volt az elképzelés, hogy az egyik tiszt nagyobb csoportot fog átadni NóGRÁDI Sándornak az Észak-Magyarországi harcok segítése céljából, akiknek a parancsnoka lett volna az egyik átadott tiszt. NóGRÁDI Sándor vele már járt is a magyar határ körzetében, felderítő úton. A német offenzíva miatt azonban a partizán osztagok parancsnokai nem nélkülözhettek fegyvereseket ezért csak a két tiszt került NóGRÁDI Sándorhoz. ${ }^{217}$

A NÓGRÁDI szovjet ejtőernyős partizán osztag 1944. X. 27-én indult el Óhegyről Donovaly irányába. Az osztag kettévált két akciócsoportra, az osztag-parancsnok az egyik akciócsoporttal tartott, a másik akciócsoport élére pedig bizalmasát nevezte ki. A második akciócsoportnak délnyugati irányban Selmecbánya-Léva irányában kellett volna haladnia. Ez az akciócsoport azonban egy német tüzérségi támadás miatt jelentős veszteségeket szenvedett. Az akciócsoporton belül jelentős viták keletkeztek. Több partizán nem látta értelmét a további harcnak ezért elhagyta az akciócsoportot. Egy nagyobb szovjet partizán osztag, amellyel találkoztak csatlakozásra szólították fel öket, illetve igényt tartott a fegyvereikre. A fegyvereiket végül átadták, azután napokig céltalanul kószáltak a hegyekben, majd feloszlatták az akciócsoportjukat úgy döntve, hogy mindenki olyan partizán osztaghoz csatlakozzon amilyenhez akar. Az osztag-parancsnok által vezetett akciócsoport azonban viszonylag épen maradva jelentette a továbbiakban az osztagot, amely 25 felfegyverzett emberből állt. Az osztag déli irányba indult. Mosód közelében töltöttek hosszabb időt. Az osztag-parancsnok megrostálta az embereit, a bizonytalankodókat rábeszélte a távozásra, vagy elküldte. ${ }^{218}$

A NÓGRÁDI szovjet ejtőernyős partizán osztag 1944. X. 10-én Lucatőnél (Besztercebánya KÉK 15 $\mathrm{km}$ ) átkelt a Garamon, és a Besztercebánya-Zólyom úttal párhuzamosan déli irányba indult. Rendkívül óvatosan haladtak. 1944. XI. 15-én Véglesnél keresztezték a Zólyom-Rutka vasútvonalat, mivel azonban nem rendelkeztek robbanóanyaggal, nem tudtak kárt tenni benne. Közben tönkre ment a rádió, így 1944. XI. 15. után az osztag már nem tudott hírt adni magáról. Ezért a 4. Ukrán Front Haditanácsa mellett müködő Partizánmozgalom Törzsének parancsnoka utasította a Besztercebánya körzetében lévő SUKEJEV szovjet ejtöernyös partizán osztagot, hogy küldjön szét összekötőket, és próbálja felvenni a kapcsolatot a NÓGRÁDI szovjet ejtőernyős partizán osztaggal. A következő napokban NÓGRÁDI Sándor megbetegedett, 
így az osztaga egy hétig vesztegeltek Szénavár térségében. 1944. XI. 28 -án az osztag törzsének parancsnoka az osztag tagjainak többségével útnak indult a magyar határ irányába, az osztag parancsnoka pedig négy társával a Hrabcsa tanyán húzta meg magát. Az éjszaka folyamán azonban német katonák támadták meg őket, ezért a partizánok az ablakon kimenekülve a már korábban útra kelt társaik után indultak, akiket másnap utolértek. A partizánok továbbra is lassan mozogtak, kilenc nap alatt $30 \mathrm{~km}$-t tettek meg. 1944. XII. 7-én Ipolytarnóc közelében átkeltek az Ipolyon, onnan 10-15 km-re, délkeletre, Karancsberény térségében (Salgótarján É $12 \mathrm{~km}$ ) rendezkedtek be, és 1944. XII. 23-ig ott maradtak. ${ }^{219}$

Az osztag létszáma folyamatosan gyarapodott. Az Ipolyon való átkeléskor a személyi állomány csak 28 fö volt, hamarosan azonban 28 német fogságból szökött szovjet hadifogoly csatlakozott hozzájuk, akik fegyvert is szereztek. Az immár mintegy 60 fös egység így már négy golyószóróval, 20 géppisztollyal, 30 puskával rendelkezett. További erősödést jelentett 40 magyar katona és csaknem 20 bányász csatlakozása. Az osztag-parancsnok a törzsét is átszervezte. 1944. XII. 22-én új bázisra települtek át, a 8 km-re, keletre fekvő Abroncspusztára. 1944. XII. 28-án egy visszavonuló német alakulat éppen az Abroncspusztán átvezető utat választotta. Váratlan megjelenésük miatt a partizánok már nem tudtak kitérni, így felvették a harcot 350-400 német katonával. Az összecsapásban a partizán osztagot szétverték, 16 fö partizán elesett, a többiek szétszéledtek. A németek elvonulása után az osztag-parancsnoknak csak 35 föt sikerült összegyüjteni. 1944. XII. 29-én megjelentek a térségben a Vörös Hadsereggel együttmúködő román csapatok. 220

NÓGRÁDI Sándor partizántevékenysége ellentmondásosan alakult. Végig arra törekedett, hogy egy nagyobb, több osztagból álló központi alakulat élén érkezzen meg Magyarországra. Ehhez embereket kért a szlovák felkelésben részt vevő szovjet partizánegységek vezetőitől, illetve a kijevi és sztanyiszlavi parancsnokságtól. Amikor a szlovák nemzeti felkelés összeomlása miatt senkitől sem kapott nagyobb ütőképes erőt, egy kis csoporttal indult útnak, de rendkívül óvatosan, indokolatlanul lassan haladt, így, mire megérkezett Salgótarján közelébe, a front már egészen közel húzódott ehhez a térséghez. Tevékenységét nem fegyveres akciók, hanem elsősorban agitáció és konspiratív munka tette ki, inkább politikusként és nem gerillavezérként viselkedett. Osztaga semmilyen jelentősebb akciót nem hajtott végre. ${ }^{221}$

Összegezve, 1944 szeptember eleje és november vége között 35 önálló ejtőernyős partizán osztag müködött hosszabb-rövidebb ideig magyar területen, Észak-Erdélyben és Kelet-Magyarországon, valamint Kárpátalján, illetve a Felvidéken továbbá Észak-Magyarországon. A ledobott ejtőernyősök létszáma 475-480 fö körül mozgott. Az osztagok közül 15 vegyes szervezésü, részben magyar vezetésü volt, 20 pedig szovjet vezetéssel, és többségében orosz, ukrán, ruszin, szlovák személyi állománnyal került bevetésre, de ezek közül 12 osztagban szintén voltak magyar származású partizánok is. A ledobott ejtőernyősök mintegy 35\%-át (165-170 föt) elfogták vagy megölték. 1944. október közepén a Sztanyiszlav melletti oprisovcei táborban további öt magyar osztag várt bevetésre 196 fős összlétszámmal. A fronthelyzet alakulásához igazodva Észak-Erdélyben 1944. IX. 20-án, Kárpátalján 1944. X. 14-én, a Felvidéken pedig 1944. X. 25-én került sor az utolsó harcoló szovjet ejtőernyős partizán osztagok bevetésére. Ezt követően már csak néhány, kisebb létszámú, felderítési feladattal megbízott osztag érkezett légi úton magyar területre. ${ }^{222}$

A 4., illetve a 2. és 3. Ukrán Front Haditanácsa mellett müködő Partizán Törzs azt tervezte, hogy a Vörös Hadsereghez csatlakozott partizán osztagok magyar tagjaiból új egységeket alakít, és ezeket az ungvári reptérről Budapest környékén, illetve a Dunántúlon vetik be. A Munkács melletti Zsukó községben különböző partizán osztagokból mintegy 70 fő magyar ejtőernyőst vontak össze. A katonai helyzet alakulása azonban ilyen típusú harcoló alakulatok alkalmazását már nem tett szükségessé. A magyar partizánokat januárban, a Magyar Kommunista Párt (MKP) kérésére Debrecenbe irányították, hogy az ideiglenes kormány katonai és rendvédelmi erejének magját alkossák. 1945. február végéig összesen 734, a Szovjetunióban antifasiszta, illetve partizán iskolát végzett magyar érkezett haza, Debrecenbe, és kapott beosztást az újjászerveződő honvédségnél és a rendőrség kötelékében. Gyors hazaszállításuknak és állományba vételüknek az volt az oka, hogy a Magyar Kommunista Párt (MKP) ezzel is igyekezett növelni a befolyását a fegyveres testületeknél. ${ }^{223}$

Szovjet részről 1944. X. 6-án Fertőd közelében dobtak le egy három fős rádiós osztagot, amely Sopron térségében végzett felderítő tevékenységet, egészen 1945. III. 30-ig. Csákberény mellett (Székesfehérvár É $20 \mathrm{~km}$ ) 1944. XI. 22-én szállt le egy másik felderítő osztag, amely Székesfehérvár térségében figyelte a német-magyar erök mozgását. Az élelemszerzést úgy próbálták megoldani, hogy elfogtak több, a katonai behívás elől az erdőben bujkáló leventét, és őket kényszerítették, hogy élelmet kérjenek a környék lakóitól. Mivel ez nem volt elegendő, 1944. XII. 3-án a partizánok bementek Mindszentpusztára és fegyverrel követeltek élelmiszert. A csákberényi, bodajki és csákvári csendőr őrs 16 csendőre, az ejtőernyős-elhárító szolgálat és egy német szakasz bekerítette a partizánok kápolnapusztai búvóhelyét. A tủzharcban egy fő 
partizán elesett, a parancsnok pedig sebesülten fogságba került. A lövöldözésben két fö levente is megsérült, egyikük belehalt a sérüléseibe. Három partizán elmenekült, de közülük két föt néhány héttel később elfogott a móri csendőrség. 1945. I. 23-án a 3. Ukrán Front Partizán Törzse öt föt dobott le Szombathely térségében. A négy férfi és a rádiós nő feladata a határ menti vasúti és közúti forgalom megfigyelése volt. 1945. I. 25-én az osztag megkísérelt beszervezni egy honvéd tiszthelyettest, aki a szombathelyi lőtéren szolgált. Az illető jelentette az esetet a feletteseinek. A kivezényelt honvéd alakulat megtalálta a partizánokat. A kibontakozó tüzharcban egy férfi és a rádiós nő meghalt, két férfi pedig megsebesült. A szökésben lévő ötödik társukat másnap egy csendőr járör őrizetbe vette. ${ }^{224}$

A Magyarországon bevetetett partizán osztagok tevékenysége messze elmaradt a szomszédos államokban folyó gerillaháború mögött. Az ország belső körzeteinek terepviszonyai alkalmatlanok voltak a partizánharcra. A bevetett partizánok nem kaptak megfelelő felkészítést, ejtőernyős kiképzést. A csoportokat ad hoc módon, gyakran csak a bevetés elötti napokban állították össze, az egységek magyar és szovjet tagjai nem tudtak kommunikálni egymással. A bevetések tervezői nem rendelkeztek helyismerettel, a szállítógépek gyakran a kijelölt célterülettől távol dobták le az ejtőernyősöket. Észak-Erdélyben nem sikerült jelentősebb partizánbázist kiépíteni. Kárpátalján a Róna-havas északi részén és a Borlóhegységben sikerült megkapaszkodniuk a partizánoknak. Mindkét esetben a sürủ erdőséggel borított hegyes terep, a kezdeti passzív, rejtőzködő magatartás, a folyamatos személyi és hadianyag utánpótlás, illetve a helyi ukrán, ruszin lakosság egy részének együttmüködése volt a kulcsa az osztagok megerösödésének. A Felvidék esetében a hosszabb ideig müködő partizán bázisokat nem magyar területen, hanem a korabeli Szlovákia területén alakították ki, és onnan intéztek támadásokat magyar célpontok ellen. A ledobott ejtőernyősök csak a harci osztagok törzseként müködtek, melyeket nagyszámú szlovák felkelő egészített ki, így jöttek létre az 1000 fős létszámot meghaladó nagy létszámú szovjet ejtőernyős partizán osztagok. ${ }^{225}$

Az ejtőernyős partizánok elleni harc legnagyobb terheit a csendőrség viselte, a helyi őrsök személyi állománya, a csendőr kerületek tanszázadai, illetve az ejtőernyős elhárító szolgálat és a polgári karhatalom, melyek rendszerint szintén csendőrségi irányítása alatt álltak. Kárpátalján több alkalommal bevontak ugyan honvéd alakulatoka is a partizánok elleni harcba, de mindig pihenöben lévő, feltöltés alatt álló csapatokat, amelyek csak néhány napig álltak rendelkezésre. Ezt követően elvonultak katonai feladataik ellátására, így a partizán osztagok ellenőrzés alatt tartása ismét a csendőrségre maradt. A honvédség részéről legfeljebb a határvadász erők vettek részt gyakrabban az ejtőernyős osztagok elleni küzdelemben. A csendőrség 1944 szeptemberéig alapvetően el tudta látni ezt a feladatot, a csendőr tanszázadok és zászlóaljak frontra vezénylése azonban nagymértékben csökkentette a hátországban rendelkezésre álló rendvédelmi erőt, miközben a partizán osztagok létszáma, tüzereje jelentős mértékben gyarapodott. A nagyobb számú, de 1944 október közepéig csak elszigetelt rajtaütések ellenére a partizántevékenység nem befolyásolta számottevő mértékben a honvédség katonai teljesítményét vagy a lakosság életviszonyait. Leküzdésükre a frontról nem kellett jelentősebb erőket elvonni, a rendvédelem és a polgári karhatalom korlátok között tudta tartani a müködésüket. Kisebb harcászati sikereik, a fennálló rendet vagy az ország védelmi képességeit alapvetően nem veszélyeztették. KÉRI Kálmán vk. ezredes, az 1. hadsereg vezérkari főnökének értékelése szerint, mindennek inkább lélektani jelentősége volt. ${ }^{226}$ 
A partizán alakulatok elnevezésének értelmezéséhez.

A szovjet ejtőernyős partizánok alakulatai egyrészt meglehetősen képlékenyek voltak, másrészt szinte semmilyen objektív paraméter tekintetében nem lehet azonosítani a korabeli regurális haderő alakulataival. Ehhez járul az is hozzá, hogy rendkívül sokféle és a valósággal nem mindig összhangban álló elnevezésekkel illették a saját szervezeteiket is. Ebből fakadóan a tanulmányban a partizán alakulatokra vonatkozóan a különböző katonai alegység típusok elnevezésének használataitól tartózkodtunk. A partizánok által a saját alakulataikra alkalmazott dandár és magasabb egység elnevezések nyilvánvalóan túlzóak voltak. Az elkeresztelt partizán alakulatok nevei pedig propagandisztikus jelleget viseltek. A meglehetősen nagyvonalúan használt korabeli és feldolgozásokban szereplő elnevezések helyett a beazonosíthatóság és az érthetőség érdekében igyekeztünk egyszerü és egyértelmű megközelítés szerinti besorolású nevekkel illetni a partizán alakulatokat.

A tanulmányban osztagnak neveztük a Szovjetunióból indított és a szovjet haderő közvetlen irányítása alatt álló ejtöernyős partizán alakulatokat függetlenül a létszámuktól, a fegyverzetüktől, a feladataiktól és a működésüktől.

A tanulmányban akciócsoportnak neveztük az osztagok alárendeltségében álló, de többé-kevésbé önállóan müködő és nem közvetlenül a szovjetunióbéli parancsnokság irányítása alá tartozó ejtőernyős partizán alakulatokat, függetlenül a létszámuktól, fegyverzetüktől, a feladataiktól és a müködésüktől.

A tanulmányban különitményeknek neveztük — általában egy osztag, vagy akciócsoport közvetlen irányítása alatt álló és annak szerves részét alkotó — azon partizán alakulatokat, amelyek függetlenül a létszámunktól, fegyverzetüktől, illetve müködésük módjától — általában valamilyen különleges feladat ellátására, illetve valamely meghatározott térségben való ténykedés céljából hoztak létre, illetve müködtettek.

A különböző partizán osztagok megkülönböztethetősége érdekében a parancsnok családi nevét is az alakulat elnevezése részének tekintettük. Abban az esetben, ha a kortársak — valamely politikai vagy propaganda megfontolásból fakadóan — nevet is adtak a partizán alakulatnak, akkor azt az elnevezést is feltüntettük az alakulat neve mellett, de csak egy esetben.

Az akciócsoportok, illetve a különítmények megnevezésében feltüntettük annak az osztagnak, illetve akciócsoportnak a nevét, amelynek az irányítása alatt álltak. (a szerk.) 
Jegyzetek:

${ }^{1}$ KAISER: 118.p. + 167.p. ; REKTOR: 214-218.p.

${ }^{2}$ PERJÉSI: 106-107.p. ; REKTOR: op.cit. 214-218.p.

${ }^{3}$ REKTOR: op.cit. 213-218.p. + 278-281.p. + 534-535.p. ; PARÁDI : A Magyar Királyi Csendőrség. Az első magyar polgári, központositott, közbiztonsági örtestület 1881-1945. 63-65.p.

${ }^{4}$ SZEMIRJAGA: 237.p.

${ }^{5}$ HEGEDÜs: 105-106.p. ; PARÁDI: A csendőrség magyarországi története. 181-182.p. ; FORRÓ: 35-36.p.

${ }^{6}$ KAISER: op.cit. 116.p. ; FERENCZY: Csendörök, honvédek harca szovjet ejtőernyős csoportokkal Magyarországon. 112120.p. ; KÖVENDY: A délvidéki partizánharcok. 168-170.p.

${ }^{7}$ GAZSI: A magyarországi ellenállási és partizánmozgalom a felszabadító hadműveletek idején. 341.p. ; GyERZSALUK: Adalékok a magyar partizánok kiképzéséhez nyújtott szovjet segítség történetéhez. 720.p.

${ }^{8}$ FERENCZY: Egyéb partizántevékenységek. 120.p. ; REKTOR: op.cit. 244-246.p. ; LIPTAI: 243.p. + 252.p.

${ }^{9}$ AleKsZEJENKO - BABIDORICS: 200-201.p.

${ }^{10}$ A PUT parancsnoka TYIMOFEJ A. Sztrokacs altábornagy, helyettese K. PONOMARENKO ezredes volt, a hadműveleti osztályt BONDAREV ezredes, a felderítő (elhárító) osztályt KOROTKOV alezredes vezette.

LIPTAI: op.cit. 252.p.

${ }^{11}$ A 4. Ukrán Front Haditanácsa mellett müködő Partizánmozgalom Törzsének vezetője Vaszilij PogREBENKO ezredes volt. GAZSI: A magyarországi ellenállási és partizánmozgalom a felszabadító hadműveletek idején. op.cit. 340-341.p. ; GYERZSALUK: Adalékok a magyar partizánok kiképzéséhez nyújtott szovjet segítség történetéhez. op.cit. 720.p. ; LIPTAI: op.cit. 243.p. +252 .p.

${ }^{12}$ KIS: Magyar partizánok a Szovjetunióból. 143-144.p. + 149.p.

${ }^{13}$ HIM-HL. MAEM VII. 205. 1/II. d. Kuznyec 189.p. ； TóTH: 11.p. ； Kis: Magyarokra nem lövünk! Egy ejtőernyős partizáncsoport története. I. 77. p. ; DÉKÁN-D. KARDOS: 449.p.

${ }^{14}$ REKTOR: op.cit. 267-268.p. ; TÖRÖK: 127-130.p.

${ }^{15}$ A haza védelme során hősi halált halt nagyajtai csendőr őrs parancsnoka KoLOzsı Nándor csendőr fötörzsőrmester volt. A sepsiszentgyörgyi szárny-parancsnok HoLLÁDI Ernő csendőr százados volt.

HOLLÁDI: 179-180.p. + 183-187.p.

${ }^{16}$ Loc.cit. 183-187.p.

${ }^{17}$ Loc.cit. 179-180.p. ; HÍDVÉGI: 108-109.p.

${ }^{18}$ A csoport tagjai voltak: DÉKÁNY István parancsnok, IHÁSZ-KovÁCs Sándor politikai helyettes, Alekszandr IZUTYINOv törzsparancsnok, FOKI József felderítő parancsnok, FuRMAN és KOLOBNYIKOV rádiós, Vaszlij BuROV robbantó, GELLÉN István orvos, Meskov András felcser, FiLebics Géza golyószórós, Schiffer (SzIGETI) Ferenc, Lebovics Izidor, Korózs Lajos, NyúL Miklós.

${ }^{19}$ A DÉKÁN szovjet ejtőernyős partizán osztag tagjai közül a földet érés során KOLOBNYIKOV és KoRÓzs életét vesztette. A hosszúmezei és a técsői csendőr őrsök járőreinek a parancsnokai TARJÁNYI József cső.ftörm. és POMÁZI Mátyás cső.ftörm. voltak. A leszállás napján fogságba került partizánok voltak GELLÉN, FOKI és NYúL, valamint IzUTYINOV. A leszállás utáni második napon esett fogságba LEBOVICS. A partizán osztag üldözése során pedig tűzharcban halt meg BuROV, IHÁSz és KovÁCS partizánok. A két életben maradt és elrejtőzött partizán FILEBICS és SCHIFFER volt.

KIS: Magyarokra nem lövünk! Egy ejtőernyős partizáncsoport története. I. op.cit. 73.p. ; DÉKÁN: 109-110.p.

${ }^{20}$ A DÉKÁN szovjet ejtőernyős partizán osztag második részének — akiket nem indítottak el Szvjatosinból a sikeres földet érést visszaigazoló üzenet miatt — a vezetöje RIESDORFER [RÉKAI] Miklós volt.

DÉKÁN: op.cit. 109-110.p.

${ }^{21}$ DÉKÁN - D. KARDOS: op.cit. 490-492.p.

${ }^{22}$ VADÁSZ: 54-55.p. ; GAZSI - HARSÁNYI: 378-381.p. ; KIS: Magyar partizánok a Szovjetunióból. op.cit. 146.p.

${ }^{23}$ A ZÁCÓ szovjet ejtöernyős partizán osztag parancsnoka ZÁCói Tivadar erdélyi magyar tiszt volt, aki román katonaként esett fogságba. Az osztag politikai helyettese V. NYIKISIN, a törzsparancsnok V. MuRATOV, a felderítö parancsnok G. TORBA voltak.

GAZSI: A magyarországi ellenállási. op.cit. 339.p. ; GAZSI - HARSÁNYI: op.cit. 578-581.p.

${ }^{24}$ A ZÁCÓI Szovjet partizán osztag földet érését a gátör a sarkadi csendör őrsnek jelezte, ahol BÉKÉs Gyula cső.ftörm. volt a paransnok.

BERTALAN: 4.p. ; TIMÁR: 7.p.

${ }^{25}$ A MALÉTER szovjet partizán osztag tagjai voltak: MALÉTER Pál hadnagy parancsnok, BALÁzs Zsigmond zászlós politikai helyettes, BogÁr György robbantó, CsőKE János golyószórós, BARTAL Károly, DruCa Sándor, MolnáR József, Fischer József, NAGy Bálint, Dezsi András (Endre), Hauer József, LÖRINC Béla, FehÉr István, SzNYATRu József, (más forrás szerint Fehér és SzNYATRu helyett SzíJÁRTó József és SÁGVÁRI István került bevetésre, A szovjet ejtőernyősök: Alekszandr Sztyepanovics JEFIMOV parancsnok-helyettes, Vaclav Marjanovics GLUHOVSZKIJ törzsparancsnok, CSEHOvsZKIJ orvos, LJUBICSENKO és KLENACS robbantó, KALACSENKO és AFOMIN rádiós.

${ }^{26}$ HORVÁTH: 25-28.p.

${ }^{27}$ Az osztag politikai helyettese BALÁzs Zsigmond volt. TóTH: op.cit. 11.p.

${ }^{28}$ A MALÉTER Szovjet ejtöernyős partizán osztag földet érésének körzetében öt csendőr örs müködött: Vámospéres (KOLOSBÓsı Gyula cső.törm), Nyírábrány (TőKÉs József cső.ftörm.), Nyíracsád (SzONDI István cső.ftörm.), Nyíradony (MEGGYEs Lajos csö.ftörm.) és Érmihályfalva (LiTKAI Ádám csö.ftörm.) településeken a jelzett személyek parancsnoksága alatt.

HIM-HL MAEM op.cit. VII. 205. Jefimov 1944. 11. 27. ; GAZsI: A magyarországi ellenállási és partizánmozgalom a felszabadító hadmüveletek idején. op.cit. 339-340.p. ; KIS: Magyarokra nem lövünk! Egy ejtőernyős partizáncsoport története. I. op.cit. 74-75.p.

${ }^{29}$ A kemecsei csendőr őrs parancsnoka KásA György csö.ftörm. volt. HIM-HL PERS. VII. 207. 232. d. 1944. 09. 20., 09. 22., 09. 28. 
${ }^{30}$ A gépből először MALÉTER vezetésével CsÖKE, CsEHOVsZKI, GLUHOVSZKI és JEFIMOV ugrottak ki. A repülőgépből másodjára kiugró négy fő partizán érkezett a szaniszlói csendőr őrs működési körzetébe, ahol TAMÁs András cső.ftörm. volt az őrsparancsnok.

HIM-HL MAEM op.cit. VII. 205. Jefimov 1944. 11. 27. ； GAZSI - HARSÁNYI: op.cit. 402-404.p. ; GAZSI: Antifasiszta ellenállás és partizánharc Magyarországon. 62-63.p.

${ }^{31}$ HORVÁTH: op.cit. 28-29.p.

${ }^{32}$ Loc.cit. 30-31.p.

${ }^{33}$ HIM-HL MAEM VII. 205. Jefimov 1944. 11. 27. ; KIs: Magyarokra nem lövünk! Egy ejtőernyős partizáncsoport története. I. op.cit. 74-75.p.

${ }^{34}$ GAZSI - HARSÁNYI: op.cit. 402-404.p. ; TÓTH: op.cit. 10.p.

${ }^{35}$ A MALÉTER szovjet ejtöernyös partizán osztag parancsnok-helyettese JEFIMOV volt, aki a kudarc okait taglaló részletes jelentést készített.

HIM-HL MAEM VII. 205. Jefimov 1944. 11. 27. ; HoRVÁTH: op.cit. 34.p.

${ }^{36}$ A csoport tagjai: RIESDORFER (RÉKAI) Miklós parancsnok, POLGÁR János politikai helyettes, Ács János golyószórós, MÉSZÁRos Sándor, KISS János, MARKOviCs János, PAPP Zsigmond, OROSZ György, valamint Andrej Nyikitovics CSERNOBROVKIN hadnagy törzsparancsnok, Nyikolaj Antonovics ZsuRAvSZKIJ felderítő parancsnok, Andrej PRUDKIN és Alekszandr Konsztantyinovics ANDRONOV rádiós, Vaszilij Feofanovics GYEKTYAREV.

${ }^{37}$ LiPTAI: op.cit. 274-275.p. ; TURCSÁNYI - HEGEDŰS: 100.p. ; TÓTH: op.cit. 11.p.

${ }^{38}$ A RIESDORFER szovjet ejtőernyős partizán osztag tartózkodási helyének felkutatásában résztvevő három csendőr őrs székhelye Aknasuhatag, Barcánfalva és Bárdfalva településeken volt, ahol örs-parancsnokok HoRvÁTH István V. cső.ftörm., MEGYESI József cső.ftörm. és BALOGH Sándor II. cső.fátörm. volt. Az aknaszlatinai csendőr század-parancsnok BÁRCZI Dezső százados volt.

KIS: Magyar partizánok a Szovjetunóból. op.cit. 152.p. ; GAZsI: A magyarországi ellenállási és partizánmozgalom a felszabadító hadmüveletek idején. op.cit. 340.p.

${ }^{39}$ GAZSI: A magyarországi ellenállási és partizánmozgalom a felszabadító hadműveletek idején. op.cit. 340.p. ; GAZSIHARSÁNYI: op.cit. 454-458.p.

${ }^{40}$ A máramarossziget csendőr őrs parancsnoka ZSADÁNYI László cső.ftörm., az aknaszlatinai csendőr század-parancsnoka pedig MOLNÁR István cső.fhdgy. volt. Az osztagon való rajtaütés során PRUDKEN orosz partizán esett el. A felderítés visszaérkező és a rajtaütés kimenetelét megfordító partizánok közül Orosz György és POLGÁR János sebesültek meg súlyosan. Az elfogott, majd elengedett próbacsendőrt SINKA Mihálynak hívták. A RIESDORFER szovjet ejtőernyös partizán osztagból kiváló orosz partizánokat CSERNOBROVKIN vezette.

GAZSI - HARSÁNYI: op.cit. 454-458.p.

41 TÓTH: op.cit. 10.p. ; LIPTAI: op.cit. 275.p.

${ }^{42}$ GAZSI - HARSÁNYI: op.cit. 326-334.p.

${ }^{43}$ ALEKSZEJENKO - BABIDORICS: op.cit. 133.p. + 147-148.p.

${ }^{44}$ Az osztag tagjai: UsZTA Gyula parancsnok, Georgij KAZNACSAJEV törzsparancsnok, Viktor GoRGYIJENKO robbantó, Mihail Gatovcov és Nyikolaj Avdonyin rádiós, Szemjon KARPOv felcser, KovÁcs István, Borbola Mihály, SÉDY Lóránd, SALAMON Márkus, DomoKos Ferenc, HalavÁCs Albert, RadÁK József, TAKÁCs József.

${ }^{45} \mathrm{Az}$ UszTA szovjet ejtöernyös partizán osztag tagjai közül a leszállás során súlyosan megsérült személy TAKÁCs József partizán volt.

MNL-OL K-149., BM Res. 274. cs., 1944-2-1019.

${ }^{46}$ UJVÁRI: 14-16.p. ; VADÁSZ: op.cit. 22-23.p. ; MolNÁR: 15.p. ; UsZTA: A jót akarni kell. 70-77.p. + 98-103.p.

${ }^{47}$ Az osztag tagjai voltak: HAMBURGER (HorvÁth) Sándor politikai helyettes, KöveCSES Ferenc, SzÉKELY Károly, OROSZ Imre, PÁPA Ferenc, Borbély Béla, Szabó Pál, IzRAEl (IHÁsz) Miklós, LaCZKó Imre, Schiller György.

${ }^{48}$ Az osztag tagjai voltak: Ivan PRISCSEPA örmester, parancsnok, Szergej KOTYELNYIKOV és Marija HAJLO rádiós, Dmitrij Usakov felcser, Pjotr Cimbaliszt, Alekszandr GladCSEnKo és Nyikolaj Szuharjov aknász, LeguckiJ, Joszif JuRIK, LEBOVITS Izidor, POLYVÁs András, Sós Géza, GÁl József.

${ }^{49}$ A hátmegi csendőr őrs parancsnoka TABAJDI Imre cső.ftörm. volt.

KosZTYÓ: Az Uszta-Priscsepa partizánosztagok tevékenysége Kárpátalján (1944. augusztus 8. - október 26.). 136-137.p. ; UszTA: A jót akarni kell. op.cit. 116-125.p. ; GIBÁs: 10-11.p. ; MolnÁR: op.cit. 50-51.p.

${ }^{50}$ GAZSI - HARSÁNYI: op.cit. 321-334.p. + 352-353.p.

${ }^{51} \mathrm{Az}$ UsZTA szovjet ejtóernyös partizán osztagnak eszerint két egyenrangú parancsnoka lett UsZTA és PRISCSEPA, a politikai helyettes HAMBURGER Sándor, a törzsparancsnok G. V. KAZNACSEJEV volt. Az 1. szakasz parancsnoka Ivan Georgij KuZMICS, politikai helyettese IZRAEL (IHÁsz) Miklós volt. A 2. szakaszt Fjodor Filipovics KRJUCSKOV vezette, a politikai helyettes posztját SÉDI Lóránd hadnagy töltötte be. A 3. szakasz Georgij Mihajlovics GLEBA (HLEBA György) parancsnoksága alatt állt, aki mellé politikai helyettesnek BORBOLA Mihályt osztották be. A robbantócsoport vezetője Viktor Ivanovics GORGYIJENKO örmester volt.

USZTA: A jót akarni kell. 143-149.p. ; GAZSI - HARSÁNYI: op.cit. 320-323.p.

${ }^{52}$ GAZSI - HARSÁNYI: op.cit. 352-353.p.

${ }^{53}$ Loc.cit.

${ }^{54}$ KosZTYÓ: Az Uszta-Priscsepa partizánosztagok tevékenysége Kárpátalján (1944. augusztus 8. - október 26.). op.cit. 138139.p. ; KosZTYó: Irreguláris szovjet katonai egységek Kárpátalján. A Rákóczi-partizánosztag müködése Kárpátalján a magyar rendvédelmi szervek iratainak tükrében. 370.p.

${ }_{55}$ A kereckei csendőr őrs helyzetéröl jelentést a Georgij MuHAMEDOv parancsnoksága alatt álló felderítő csoport tett. A kereckei csendőr őrsöt KRJUCSAKOV által vezetett szakasz átámadta meg. A kereckei csendőr őrs elleni támadásban MuHAMEDOV és Mihail Petrovics CsEKALKIN sebesült meg.

GAZSI - HARSÁNYI: op.cit. 326-327.p. ； KOSZTYÓ: Az Uszta-Priscsepa partizánosztagok tevékenysége Kárpátalján (1944. augusztus 8. - október 26.). op.cit. 140-141.p. 
${ }^{56}$ A községházára betörő és GÁLos Lajos körjegyzőt megölő partizánokat HALAVÁCS Albert partizán vezette. A szolyvai út mentén lesállást foglaló partizánokat Iván KuZMICS vezette.

HIM-HL. PERS. op.cit. VII. 207. 232. d. 1944. 09. 22. ; UsZTA: A jót akarni kell. op.cit. 154-156.p. ； UJVÁRI: op.cit. 2931.p.

${ }^{57}$ HIM-HL. PERS. op.cit. VII. 207. 232. d. 1944. 09. 22.

${ }^{58}$ Loc.cit. VII. 207. 232. d. 1944. 09. 26. ; KoszTYÓ: Az Uszta-Priscsepa partizánosztagok tevékenysége Kárpátalján (1944. augusztus 8. - október 26.). op.cit. 372.p.

${ }^{59}$ a kárpátaljai katonai körzet parancsnoka FeHÉR Géza vörgy. volt. A Borló hegység körüli megszállt falvak közé tartozott Babarét, Kenézpatak, Oláhcsertész, Ilonca, Zárnya, Szuhabaranka, Kerecke, Zajgó, Lombos, Malmos, Kishídvég és Ormod is. GAZSI - HARSÁNYI: op.cit. 334-335.p.

${ }^{60}$ Loc.cit. 354-356.p.

${ }^{61}$ HIM-HL. PERS. op.cit. VII. 207. 232. d. 1944. 09. 25. ; GAZSI - HARSÁNYI: op.cit. 328-329.p. ； UJVÁRI: op.cit. 3132.p.

${ }_{62}^{62}$ HIM-HL. PERS. op.cit. VII. 207. 232. d. 1944. 09. 25., 1944. 09. 26.

${ }^{63}$ a Gombástelep körzetében a lóvontatású hegyiágyúkkal rendelkező menetszázadon való rajtaütés során a partizánok közül meghalt Fjodor KRJUCSKov, Szergej ANTONOv és Nyikolaj ZAJAN. A halálesetek miatt a különítmény vezetését ideiglenesen SALAMON Márkus vette át.

KosZTYó: Az Uszta-Priscsepa partizánosztagok tevékenysége Kárpátalján (1944. augusztus 8. - október 26.). op.cit. 142-143.p. ; UJVÁRI: op.cit. 23-24.p. ; KosZTYÓ: Irreguláris szovjet katonai egységek Kárpátalján. A Rákóczi-partizánosztag müködése Kárpátalján a magyar rendvédelmi szervek iratainak tükrében. op.cit. 371-372.p.

${ }^{64} \mathrm{Az}$ osztaghoz csatlakozó szovjet repülő tisztek Ivan Sz. PECSERSZKI gárdaszázados és Leonyid N. MATASzOV gárdaőrnagyok voltak, akiket az 1. illetve a 2. szakasz parancsnokává neveztek ki. A harmadik szakasz parancsnoki tisztségét Georgij Mihajlovics GLEBA (HLEBA György) be.

GAZSI - HARSÁNYI: op.cit. 320-326.p. ; ALEKSZEJENKO - BABIDORICS op.cit. 201-202.p.

${ }^{65}$ HIM-HL. PERS. op.cit. VII. 207. 232. d. 1944. 09. 26. ; HEGEDÜS - TURCSÁNYI: op.cit. 100.p. ; GAZSI - HARSÁNYI: op.cit. 354-356.p.

${ }^{66}$ HIM-HL. PERS. op.cit. VII. 207. 232. d. 1944. 09. 28. ; GAZSI - HARSÁNYI: op.cit. 325-326.p.

${ }^{67}$ KosZTYÓ: Irreguláris szovjet katonai egységek Kárpátalján. A Rákóczi-partizánosztag müködése Kárpátalján a magyar rendvédelmi szervek iratainak tükrében. op.cit. 372-373.p.

${ }^{68}$ AlEKSZEJENKO - BABIDORICS: op.cit. 202-204.p.

${ }^{69}$ Loc.cit. 206-207.p.

${ }^{70}$ UszTA: A jót akarni kell. op.cit. 163-164.p. ; KoszTYÓ: Az Uszta-Priscsepa partizánosztagok tevékenysége Kárpátalján (1944. augusztus 8. - október 26.). op.cit. 146.p. ; GAZSI - HARSÁNYI: op.cit. 328-329.p.

${ }^{71}$ HIM-HL. KSZV. I. 94. 1944. 09. 05. ; UsZTA: Rákóczi neve alatt... 150.p. ; GAZSI - HARSÁNYI: op.cit. 358-359.p.

${ }^{72}$ MNL-OL. K-150. BM.Eln. 3584. cs. 1944-V-7. ; HIM-HL. PERS. VII. 207. 232. d. 1944. 10. 10., 1944. 10. 20.

${ }^{73}$ A 4. Ukrán Front Partizán Törzsének parancsnoka PogREBENKo ezredes volt.

GYERZSALUK: Adalékok a magyar partizánok kiképzéséhez nyújtott szovjet segítség történetéhez. op.cit. 720.p. ; ALEKSZEJENKO - BABIDORICS: op.cit. 207.p.

${ }^{74}$ MNL-OL. K-150. op.cit. BM.Eln. 3584. cs. 1944-V-7. ; HIM-HL. PERS. op.cit. VII. 207. 232. d. 1944. 10. 20.

${ }^{75}$ HIM-HL. 1.HDS. II. 1452. 1. d. Tiszti parancs 37/1944. ； ALEKSZEJENKO-BABIDORICS: op.cit. 207-208.p. ; UsZTA: A jót akarni kell. op.cit. 166.p.

${ }^{76}$ HIM-HL. PERS. op.cit. VII. 207. 232. d. 1944. 10. 13. ; GAZSI - HARSÁNYI: op.cit. 328-329.p. ; KosZTYÓ: Irreguláris szovjet katonai egységek Kárpátalján. A Rákóczi-partizánosztag müködése Kárpátalján a magyar rendvédelmi szervek iratainak tükrében. op.cit. 376.p.

${ }^{77}$ MNL-OL. K-150. BM.Eln. 3584. cs. 1944-V-7. ; HIM-HL. PERS. VII. 207. 232. d. 1944. 10. 13. ; UJVÁRI: op.cit. 37-38.p.

${ }^{78}$ HIM-HL. PERS. VII. 207. 232. d. 1944. 10. 13. ; MNL-OL. K-150. BM.Eln. 3584. cs. 1944-V-7. ； UJVÁRI: op.cit. 32-35.p.

${ }^{79}$ KosZTYÓ: Irreguláris szovjet katonai egységek Kárpátalján. A Rákóczi-partizánosztag müködése Kárpátalján a magyar rendvédelmi szervek iratainak tükrében. op.cit. 376.p. ; ALEKSZEJENKO - BABIDORICS: op.cit. 208-209.p.

${ }^{80}$ GAZSI - HARSÁNYI: op.cit. 358-361.p.

${ }^{81} \mathrm{Az}$ 1944. X. 16-ai akciót végrehajtó különítmény parancsnoka HALAVÁcs Albert, az 1944. X. 17-ei akció parancsnoka pedig Alekszandr Grigorjevics MELENTYEV robbantási szakember irányításával valósult meg, ahol a parancsnok Viktor GoRGYIJENKO volt.

ALEKSZEJENKO - BABIDORICS: op.cit. 208-209.p. ; UJVÁRI: op.cit. 35-37.p.

${ }^{82}$ Az 1944. X. 19-ei és 20-ai robbantások müszaki kivitelezője Tyimofej Alekszejevics POTAPOV és SALAMON Márkus robbantásszakértők voltak, akik Pjotr Nyikolajevics CIMBALISZT által vezetett különítménybe voltak beosztva.

KosZTYÓ: Az Uszta-Priscsepa partizánosztagok tevékenysége Kárpátalján (1944. augusztus 8. - október 26.). op.cit. 146-147.p. ; ALEKSZEJENKO - BABIDORICS: op.cit. 207-208.p.

${ }^{83}$ A hátmegi csendör örs parancsnoka BARNA Mihály cső.ftörm. volt.

HIM-HL. PERS. op.cit. VII. 207. 232. d. 1944. okt. 20. ; KöVENDY: A martinkai ütközet. 158.p.

${ }^{84}$ Az oláhcsertészi rajtaütést megvalósító különítmény parancsoka Georgij Mihajlovics GLEBA (HLEBA György) volt.

UsZTA: Rákóczi neve alatt. op.cit. 150-151.p. ; GAZSI - HARSÁNYI: op.cit. 330-332.p. + 358-361.p.

${ }^{85}$ UJVÁRI: op.cit. 48-49.p. ; GAZSI - HARSÁNYI: op.cit. 331-332.p. ; ALEKSZEJENKO - BABIDORICS: op.cit. 210-213.p.

${ }^{86}$ A partizánok ellen kivezényelt csendőrök parancsnokául KöVENDY Károly csendőr főhadnagyot nevezték ki. A megerősítésükre érkezett csendőr századot pedig BÁRCZY Dezső cső.szds. vezette.

REKTOR: op.cit. 276.p. ; KöVENDY: Csendőrök és partizánok harca a Kárpátokban. 144-145.p. ; KoszTYÓ: Az UsztaPriscsepa partizánosztagok tevékenysége Kárpátalján (1944. augusztus 8. - október 26.). op.cit.p.

${ }^{87}$ A Végmártonkát visszafoglaló ütközet vezetői XANTuS György honv.hdgy. és SimON András cső.fhdgy. volt. A honvéd tiszt a vádliján, a csendőrs tiszt pedig a vállán sebesült meg az ütközet során.

KÖVENDY: A martinkai ütközet. op.cit. 159.p. ; REKTOR: op.cit. 245-246.p. 
${ }^{88}$ A Munkács védelmére vezényelt csendőri erők közül partizán elhárítási feladatot kapott csendőr szakasz parancsnoka SERES cső.hdgy. volt.

FERENCZY: Csendőrök, honvédek harca szovjet ejtőernyős csoportokkal Magyarországon. op.cit. 111-121.p. ; KöVENDY: KÖVENDY: Csendőrök és partizánok harca a Kárpátokban. op.cit. 144-145.p.

${ }^{89}$ Az 1944. X. 25-én a 4. honvéd hegyi zászlóalj elleni rajtaütést az UszTA szovjet ejtőernyős partizán osztag különítményét Georgij Mihajlovics GLEBA (HLEBA György) vezette. A védekező honvédeket hátba támadó partizánokat — akik az USZTA szovjet ejtöernyös partizán osztag másik különítményéhez tartoztak — Georgij KAZNACSAJEV vezette. Az 1944. X. 25-én a Boród térségén áthaladó honvéd tüzér alakulatot megtámadó USZTA szovjet ejtőernyős partizán osztag különítményét Iván Sz. PECSERSZKI gárdaszázados vezette.

HIM-HL. TGY. 3309. Lóskay 9.p. ; GAZSI-HARSÁNYI: op.cit. 332-333.p. ; KosZTYÓ: Az Uszta-Priscsepa partizánosztagok tevékenysége Kárpátalján (1944. augusztus 8. - október 26.). op.cit. 149.p.

${ }^{90}$ GAZSI - HARSÁNYI: op.cit. 320-323.p. + 358 - 361.p. ; UJVÁRI: op.cit. 39.p. ; UsZTA: A jót akarni kell. op.cit. 202.p.

91 ALEKSZEJENKO - BABIDORICS: op.cit. 212-213.p. ; LIPTAI: op.cit. 336.p. ; TÓTH: op.cit. 10.p.

${ }^{92}$ Az osztag tagjai voltak: Alekszandr TKANKO parancsnok, Alekszej SZTRAH politikai helyettes, Szamuil MARINYENKO törzsparancsnok, Zinajda KrisZTYANYinOva és Artas GaSZPARJAn rádiós, Kaszim KaJSZENOV, Alekszej Potilenko, Konsztantyin SZPJEzSEvoj, Ciala Dzsavahia, Dmitrij Pop, Mihail AszTAFJev, Alekszej AleKSZEJenKo, JAKUBovics András tolmács.

${ }^{93}$ PUSKAS: 416.p. ; ALEKSZEJENKO - BABIDORICS: op.cit. 100-104.p. + 118-123.p.

${ }^{94}$ ALEKSZEJENKO - BABIDORICS: op.cit. 126-127.p. + 133-138.p.

${ }^{95}$ A magyar rendfenntartó erők által 1944. VIII. 31 -én a Róna-havas térségében indított nagyszabású tisztogató akció vezetöje FeHÉR Géza honv.vörgy. volt

REKTOR: op.cit. 244-245.p. ； KÖVENDY: Csendőrök és partizánok harca a Kárpátokban. op.cit. 143-144.p. ； KöVENDY: Csendörök a Kárpátokon. Egy csendörtiszt naplója Magyarország történelmének legnehezebb és legszomorúbb idejéböl. ; ÖLVEDI: Emlékek és adalékok néphadseregünk születéséhez.

${ }^{96}$ HIM-HL. PERS. op.cit. VII. 207. 232. d. 1944. 09. 01. ; KöVENDY: Csendörök és partizánok harca a Kárpátokban. op.cit. 139-140.p.

${ }^{97}$ Az osztag tagjai voltak: Jakov VANJAGin parancsnok, Mihail SCSETYinYin, Ivan BANDURKA, Borisz FAJZULin, Tamara BEZSZUDNOVA rádiós, Willi RoMAN.

${ }^{98}$ A leszállásnál Jakov VANJAGIN parancsnok és Ivan BANDURKA megsérültek. a lipcsei csendőr őrs parancsnoka MEGYER György cső.ftörm., az alsóbisztrai csendőr őrs parancsnoka POLGÁR János cső.ftörm., a kövesligeti csendőr örs .parancsnoka VLASZ István cső.ftörm. volt. A partizán osztag két tagját, Tamara BEZSZUDNOVA-át és Willi RoMAN-t a leszállás követően néhány órával elfogták.

ALEKSZEJENKO - BABIDORICS: op.cit. 198-199.p.

${ }^{99} \mathrm{Az}$ ilosfai csendőr örs parancsnoka TőKÉs József cső.ftörm. volt.

Loc.cit. 144-145.p.

${ }^{100}$ OfICINSZKIJ: 214-215.p. ; ÖLVEDI: Az 1. magyar hadsereg története, 1944. január 6-ától október 17-éig. op.cit. 138.p.

${ }^{101}$ Az osztag ismert tagjai voltak: Vitalij A. BOLOTNYIKOv föhadnagy parancsnok, Alekszej B. LoBENKO politikai helyettes, Szemjon P. GusZEV hadnagy törzsparancsnok, Vaszilij I. DuBOSKIN felderítő parancsnok, Rogyion P. ZAJKIn és Leonyid A. SCSERBAKOV robbantó, Szergej Sz. MELENTEV orvos, Zsana F. LAVINA felcser, Bogdan T. DravKo és Natasa K. LOMNICKAJA rádiós.

${ }^{102}$ MNL-OL. K-150. op.cit. BM.Eln. 3584. cs. 1944-V-7.

${ }^{103}$ A munkácsi csendőr őrs parancsnoka SzABÓ Lajos cső.ftörm., a szolyvai csendőr őrs parancsnoka épedig Izsó Ambrus csö.ftörm. volt.

HIM-HL. PERS. op.cit. VII. 207. 232. d. 1944. 09. 09.

${ }^{104}$ HIM-HL. PERS. VII. 207. 232. d. 1944. 09. 11.

${ }^{105}$ Az osztag tagjai voltak: RuSZIN, Ivan Petrovics SZENDER őrnagy törzsparancsnok, Nyikolaj LoGOJDA felderítő parancsnok, Dmitrij Volcsenko mesterlövész, Lenyina Dzsanajeva rádiós, Anasztaszia Fedoszejeva rádiós, Vlagyimir PaVLENKo rádiós, Dmitrij Kerecsun, Pavel Zozulua, Jurij Kurin, Andrej Miletyenkov.

${ }^{106}$ A RUSzIN szovjet ejtőernyős osztag 1944. IX. 7-én földet ért tagjai közül az elsodródott rádiós Lenyina DzSANAJEVA volt. HIM-HL. PERS. VII. 207. 232. d. 1944. 09. 01. ； KöVENDY: Csendőrök és partizánok harca a Kárpátokban. 139-140.p. ; ALEKSZEJENKO - BABIDORICS op.cit. 157-158.p.

${ }^{107}$ Az osztagtagjai: Ivan I. FABRICIN politikai helyettes, Ilja PECSKAN mesterlövész, Vjacseszlav HARKAVENKO orvos, Ciara GLÜCk felcser, Luka SzvjatinYa, Vaszilij Misko, Ivan SEBA, Mihail Ruszin és Ivan PopOvics, Pjotr HLuSKo és Vlagyimir TuRIK.

${ }^{108}$ HIM-HL. PERS. VII. 207. 1944. 09. 01., 1944. 09. 25. ; LIPTAI: op.cit. 282.p.

${ }^{109}$ A polenai csendőr őrs parancsnoka GÁL András cső.ftörm., a poroskői csendőr őrs parancsnoka pedig AszTALOS József cső.ftörm. volt.

ALEKSZEJENKO - BABIDORICS: op.cit. 220-223.p.

${ }^{110}$ HIM-HL. PERS. op.cit. VII. 207. 232. d. 1944. 09. 28.

111 ALEKSZEJENKO - BABIDORICS: op.cit. 235-239.p.

${ }^{112}$ Loc.cit. 240-242.p. + 246-247.p.

${ }^{113}$ MNL-OL. K-150. op.cit. BM.Eln. 3584. cs. 1944-V-7. ; ALEKSZEJENKO-BABIDORICS: op.cit. 248-254.p.

${ }^{114} \mathrm{Az}$ Uzsoki-hágó térségében müködő akciócsoport Mihail HoLOvKo vezetése alatt állt, törzsparancsnoka pedig Ivan NAHORNOV volt, aki még júliusban érkezett a SzOPILKO szovjet ejtőernyős osztag tagjaként. Az osztag a szétverése után pedig a TKANKO szovjet ejtöernyös partizán osztaghoz csatlakozott. A Huszt térségébe tevékenykedő akciócsoport parancsnoka MELNYIKOV, törzsparancsnoka pedig Andrej ILJIN volt, akiket még májusban dobtak le ejtőernyővel és az osztaguk felszámolása után csatlakoztak a TKANKO szovjet ejtöernyös partizán osztaghoz.

ALEKSZEJENKO - BABIDORICS: op.cit. 147-148.p.

${ }^{115}$ Loc.cit. 158-159.p.

${ }^{116} \mathrm{Az}$ alsókerepeci csendőr őrs parancsnoka KATHY Sándor cső.ftörm. volt.

MNL-OL. K-150. BM.Eln. 3584. cs. 1944-V-7.

${ }^{117}$ ALEKSZEJENKO - BABIDORICS: op.cit. 160-162.p. 
${ }^{118}$ Szarvaskút és Túrjasebes között tevékenykedő akciócsoport vezetője Dimitrij Pop volt. A Rónahavas déli részén elhelyezkedő akciócsoport vezetője KAJSZENOv, Túrjaremete és Antalóc közötti térségben működő akciócsoport vezetője pedig MILETYENKOV volt.

Loc.cit. 163-165.p.

${ }^{119}$ Az ungvári nyomozó csendőr alosztály személyi állományába tartozó DOMBÓVÁRI József cső.örm. vesztette életét 1944.

IX. 17-én Szerencsfalva térségében.

HIM-HL. PERS. op.cit. VII. 207. 232. d. 1944. 09. 18., 1944. 09. 20. ; Hősi halált haltak. 657.p.

${ }^{120}$ HIM-HL. PERS. op.cit. VII. 207. 232. d. 1944. 09. 26., 1944. 09. 28.

121 ALEKSZEJENKO - BABIDORICS: op.cit. 170.p.

${ }^{122}$ Az Ungvár-Perecseny föútvonal mentén tevékenykedő akciócsoport parancsnoka SvEC volt. A perecsenyi csendőr őrs parancsnoka TAKÁCS Imre cső.ftörm. volt.

HIM-HL. PERS. op.cit. VII. 207. 232. d. 1944. 10. 10. ； MNL-OL. K-150. op.cit. BM.Eln. 3584. cs. 1944-V-7.

${ }^{123}$ A rosztovatovci településen a partizánok által megölt személy KRISZAK erdész volt.

HIM-HL. PERS. op.cit. VII. 207. 232. d. 1944. 10. 10. ; ALEKSZEJENKO-BABIDORICS: op.cit. 166-168.p.

${ }^{124}$ A Dombó melletti légvédelmi figyelő őrsön rajtaütö akciócsoport parancsnoka MELNYIKOV volt. Ugyancsak MELNYIKOV vezette a Huszt-Máramarossziget vasútvonalon Úrmező térségében sikeres robbantást végrehajtó akciócsoportot.

MNL-OL. K-150. op.cit. BM.Eln. 3584. cs. 1944-V-7.

${ }^{125}$ A TKANKO szovjet ejtöernyös partizán osztag a HOLOVKO által vezetett akciócsoportjának három különítményét Vaszilij Kustan, Iván KuPLISIN és Nyikolaj GaLAGOVEC vezette.

ALEKSZEJENKO - BABIDORICS: op.cit. 176-179.p.

${ }^{126}$ HIM-HL. PERS. op.cit. VII. 207. 232. d. 1944. 10. 13., 1944. 10. 20.

127 1944. X. 18-án a Túrjasebest megtámadó partizán akciócsoportok vezetői SzEzSEvoJ, SzoPILKo és PoP volt. A Patakos település ellen 1944. X. 18-án éjszaka végrehajtott rajtaütést végrehajtó akciócsoportok parancsnoka KASZJONOV és SvEC volt. Loc.cit. VII. 207. 232. d. 1944. okt. 10. ; MNL-OL. K-150. op.cit. BM.Eln. 3584. cs. 1944-V-7.

${ }^{128} \mathrm{Az}$ 1944. X. 23-án Túrjavágásra érkező honvéd utász .északaszon rajtaütő három partizán akciócsoport vezetői voltak SZOPLIKO, SZPERZSEVOJ és SVEC. A partizánok részéről megsebesült személy SZPERZSEVOJ volt.

ALEKSZEJENKO - BABIDORICS: op.cit. 174-175.p.

${ }^{129} 1944$ októberében az Alsószlatina térségében magyar zászlóaljat megtámadó négy partizán akciócsoport parancsnokai voltak KAJSZENOV, SZOPLiKo, SveC és MiLETYNKOV.

LIPTAI: op.cit. 329-330.p.

${ }^{130}$ REKTOR: op.cit. 274-277.p. ; KÖVENDY: Csendörök a Kárpátokon. Egy csendőrtiszt naplója Magyarország történelmének legnehezebb és legszomorúbb idejéböl. op.cit. 81-82.p. ; KöVENDY: Egy arany vitézségi érem és egy lovagkereszt története. 149-156.p.

131 A 4. Ukrán Front Partizán Törzsének parancsnoka V.Sz. POGREBENKO ezredes volt.

Az osztag magyar tagjai voltak: LENCSÉs János politikai helyettes, CSERBA (DEMÉNDI) Lajos törzsparancsnok, SÜTÖ (CIFRA) László golyószórós, SiPos Gyula mesterlövész, GARAi Bertalan, SuRÁNYi Károly, JuHÁsz Mihály, BerÉNYi Dezső, BuKOR Kálmán, MiKLÓs Antal, Simon Ferenc, PÁszTor Tibor, ERŐs Dénes, TORONYI Iván, SÜTŐ László, valamint CsETE István, EGED András, IHÁsz Miklós, GomBos Béla. Az osztag szovjet tagjai voltak: Vaszilij JAKOvENKo felderítő parancsnok, Vlagyimir SCSERBAKOV, Alekszandr LARKIN robbantó, Vlagyimir PANOV orvos, Valentyin PoGUGYIN robbantó, Vaszilij GONCSAROV rádiós, Jekatyerina SZTASEVSZKAJA rádiós, Bekmurat TuRSZUMURATOV.

${ }^{132}$ CSIFFÁRY: 53-54.p. ; ALEKSZEJENKO - BABIDORICS: op.cit. 168-169.p. ; TÓTH: op.cit. 11.p.

${ }^{133}$ A földet éréskor PANOV, BUKOR és MIKLÓs Antal partizán törte lábát, BuJANOV és LENCSÉs partizánok pedig távolra sodródtak. LIPTAI: op.cit. 85.p. ; GYERZSALUK: A Bujanov-Lencsés partizáncsoport tevékenysége. 540.p.

${ }^{134} \mathrm{Az}$ ókemencei csendőr őrs parancsnoka SZILÁGYI István cső.ftörm. volt. A BUJANOV szovjet ejtöernyös partizán osztag által végrehajtott éjszakai erőltetett menet során az osztagtól leszakadt CsERBA, ERŐs Dénes, SÜTŐ László, GARAI Bertalan és TORONYI Iván.

KIs: Magyarokra nem lövünk! Egy ejtőernyős partizáncsoport története. I. op.cit. 74.p. ； GYERzSALuK: A Bujanov-Lencsés partizáncsoport tevékenysége. op.cit. 543-544.p.

${ }^{135}$ GYERZSALUK: A Bujanov-Lencsés partizáncsoport tevékenysége. op.cit. 542-544.p.

${ }^{136}$ A megsebesült BujANOv helyébe Valentyin POGUGYin lépett.

CSIFFÁRY: op.cit. 53-54.p. ; GAZSI: A magyarországi ellenállási és partizánmozgalom a felszabadító hadműveletek idején. op.cit. 340-341.p. ; LIPTAI: op.cit. 53-54.p.

137. LIPTAI: op.cit. 53-54.p. ; GYERZSALUK: A Bujanov-Lencsés partizáncsoport tevékenysége. op.cit. 545-546.p.

138 GAZSI: A magyarországi ellenállási és partizánmozgalom a felszabadító hadműveletek idején. op.cit. 340-341.p. ; CSIFFÁRY: op.cit. 53-54.p. ; LIPTAI: op.cit. 53-54.p.

${ }^{139}$ OfICINSZKIJ: op.cit. 209-215.p. ; GYERZSALUK: Adalékok a magyar partizánok kiképzéséhez nyújtott szovjet segítség történetéhez. op.cit. 721.p.

${ }^{140}$ SZEMIRJAGA op.cit. 312-313.p. ； DÉKÁN - D. KARDOS: op.cit. 517-518.p. ； GAZSI - HARSÁNYI: op.cit. 399-400.p.

141 KÜHNRICH: 172-174.p.

${ }^{142}$ HARSÁNYI: op.cit. 475-477.p. ; KIs: Magyarokra nem lövünk! Egy ejtőernyős partizáncsoport története. I. op.cit. 77-78.p.

${ }^{143}$ A partizán osztag tagjai voltak: SZÖNYI Márton hadnagy parancsnok, ÖsZ-SZABÓ József politikai helyettes, Grigorij Alekszejevics NovOTNIJ törzsparancsnok, Vlagyimir Grigorjevics SZEMENYUK és Larisza POLNYICKAJA rádiós, Vlagyimir ZsILJAJEV robbantó, Jevgenyij LJONOv orvos, CsizMADia Gyula mesterlövész, BALI Ferenc golyószórós, SzotáK Mihály, Kiss Benjamin, BRÁz Lajos, MOLNÁR István.

${ }^{144}$ FÖLDES: 162-163.p. ; 170-177.p.

${ }^{145} \mathrm{Az}$ 1944. VIII. 8-án Tarnalelesz térségében földet érő SZŐNYI szovjet ejtőernyős partizán osztag tagjaitól elsodródó három ejtőernyős Csizmadia Gyula, Kiss Benjámin és BALI Ferenc volt.

HIM-HL. PERS. op.cit. VII. 207. 232. d. 1944. 08. 11., 1944. 08. 18. ; FöLDES; op.cit. 162-172.p. + 176-180.p. ; KIS: Magyar partizánok a Szovjetunióból. op.cit. 145.p. ; GIBÁs: op.cit. 9-10.p. 
${ }^{146}$ Az 1944. VIII. 17-én Laczópadjánál tűzharcba keveredett három partizán közül a súlyosan megsebesült Ősz-SzABó József és Grigorij Alekszejevics NovOTNIJ a későbbiek folyamán belehalt sérüléseibe.

HIM-HL. PERS. op.cit. VII. 207. 232. d. 1944. 08. 18. ; FERENCZY: Egyéb partizántevékenységek. op.cit. 119-120.p. ; FÖLDES: op.cit. 212-219.p.

${ }^{147}$ Az 1944. VIII. 19-én Domaháza-Gesztete térségében földet ért szovjet ejtőernyős partizán osztag vezetője Vaszilijevics FJODOROV örnester, a politikai helyettes pedig SZABÓ József volt. A felkutatásukra vezényelt csendőröket FERENCZY cső.alhdgy. vezette.

FERENCZY: Csendőrök, honvédek harca szovjet ejtőernyős csoportokkal Magyarországon. op.cit. 120.p.

148 1944. VIII. 30-án a csendőrök SzOTÁKOT, 1944. IX. 2-án pedig BRÁz és MOLNÁR partizánokat fogták el. A BRÁZT és MOLNÁRT elfogó csendőrök a rudabányai csendőr örs beosztottjai voltak, ahol az örsparancsnoki tisztséget MÁRTON Károly cső.ftörm. töltötte be. A SZÖNYI szovjet ejtöernyös partizán csoport parancsnokát tüzharcban megölö csendőrök részben a hagonyi csendőr őrs beosztottjai voltak, ahol a parancsnoki tisztséget BÁNÓCZI János cső.ftörm. töltötte. Az osztagparancsnokot bekerítő csendőrök parancsnoka TóTH József cső.törm. volt.

HIM-HL. PERS. op.cit. VII. 207. 232. d. 1944. 09. 18. ; FöLDES: op.cit. 223.p.; DÉKÁN-D. KARDOS: op.cit. 306.p.

${ }^{149}$ LIPTAI: op.cit. 303-304.p.

${ }^{150}$ Az osztag tagjai voltak: Alekszej Mihajlovics SzAGYILENKO parancsnok, V. KLOKOv politikai helyettes, D. REZUTO törzsparancsnok, V. I. KALENKOv rádiós, N. M. KLIMOV, Grigorij CSERNYAHOvsZKiJ orvos és Zina TyiTOVA felcser, valamint SiMKO Sándor, WeISz Ernő, HoRváth Ferenc, STRASSER Frigyes, SupIK Miklós, BuRJÁN Viktor, LÁszló Éva.

${ }^{151}$ SZAGYILENKO: 560.p. ; LIPTAI: op.cit. 132.p.

152 A SZAGYILENKO szovjet ejtőernyös partizán osztag magyar akciócsoportjának parancsnoka Andrej FuTYANOv, politikai helyettese SIMKo Sándor, törzsparancsnoka Nyikolaj Kulikovics CSERNYAKOvsZKIJ volt. A SZAGYILENKO szovjet ejtöernyös partizán osztag dandárrá átnevezésekor a politikai helyettesi feladatokat V.I. KALENKOV, a törzsparancsnoki posztot pedig N.M. KLIMOV töltötte be.

SZAGYILENKO op.cit. 563-564.p.

${ }^{153}$ HIM-HL. MAEM. op.cit. Kuznyec 1/II. d. ； TóTH: op.cit. 11.p. ； KIs: Magyarokra nem lövünk! Egy ejtőernyős partizáncsoport története. I. op.cit. 77.p.

${ }^{154}$ Az osztag tagjai voltak: J. M. KK parancsnok, V. V. MiHAJLOvszKiJ törzsparancsnok, D. A. Szuszlov felderítő parancsnok, V. P. BugyenKo és K. Vlagyimirov rádiós, N. F. Szologyuk orvos, V. I. CsuPRiJanOva felcser, J. M. LaPSOV robbantó, valamint MolonTAY Károly hadnagy, a magyar részleg parancsnoka, CsIPAi Ferenc, Dobos Zsigmond, GenCSi Sándor, KESZTENBAUM (Kovács) Imre mesterlövész, Kis András, NAGy László, NAGY Mihály (valódi neve, Gyulai Károly), NÉMETH Károly, PAPp Lajos, Szabó András, VARGa János, GrestyÁk (GAlambos) István. A csoportnak eredetileg tagja volt VARGA István is, ő azonban betegségre hivatkozva az utolsó pillanatban visszalépett, helyére került be GRESTYÁK István.

${ }^{155}$ A KUZNYEC szovjet ejtöernyös partizán osztag magyar részlegének a vezetésével MOLONTAY KÁROLY hadnagyot bízták meg. Mivel az osztag magyar és orosz tagjai csak tolmács útján tudtak érintkezni az tolmácsa NAGY László volt.

HIM-HL. MAEM Kuznyec 1/II. d. ; KIs: Magyarokra nem lövünk! Egy ejtőernyős partizáncsoport története. I. op.cit. 7780.p. ; CSIFFÁRY: op.cit. 65.p.

${ }^{156}$ A részeg orosz felderítő parancsnok Dimitrij SZUSZLOV, akinek pedig a lábára esett GRESTYÁK István magyar partizán volt. A tarnaleleszi csendőr őrs parancsnoka KovÁcs Balázs cső.ftörm., az egercsehi csendőr őrs parancsnoka pedig FeHÉR János cső.ftörm. volt.

TóTH: op.cit. 11.p. K KIs: Magyarokra nem lövünk! Egy ejtőernyős partizáncsoport története. II. 61-62.p.

${ }^{157}$ A KUZNYEC szovjet ejtőernyös partizán osztag földet érését követően lemaradó három fö a sérült lábú GRESTYÁK (GALAMBOS) István és a vele tartó NAGY László és Kis András partizánok voltak. A súlyosan sérült V.P. BUGYENKO is lemaradt az osztagtól. NAGY László partizánt mint áruló magyar katonaszökevényt a helyszínen agyonlötték.

HIM-HL. PERS. op.cit. VII. 207. 232. d. 1944. 09. 09. ; KIs: Magyarokra nem lövünk! Egy ejtőernyős partizáncsoport története. II. 63-64.p. FERENCZY: Csendőrök, honvédek harca szovjet ejtőernyős csoportokkal Magyarországon. op.cit. 120-121.p.

${ }^{158}$ A magát önkéntesen feladó partizán DoBos Zsigmond volt.

HIM-HL. PERS. op.cit. VII. 207. 232. d. 1944. 09. 15. ; Tóтн: op.cit. 10.p.

${ }^{159}$ A gesztetei föjegyző által vezetett partizán elhárító alakulat a partizánok elhelyezkedéséről a feledi csendőr őrsöt tájékoztatta, ahol KÁLMÁNYHELYI Sándor cső.ftörm. volt a parancsnok. A partizánokat az egyik erdőből a másikba LisZKAI István erdőőr vezette. Az erdészek által megtalált sebesült partizán neve KeSZTENBAUM (KovÁCS) Imre volt. A fákon fennakadt partizán GENCSI Sándor volt.

KIs: Magyarokra nem lövünk! Egy ejtőernyős partizáncsoport története. II. op.cit. 66-69.p. ; GAzsI: A magyarországi ellenállási. op.cit. 339.p.

${ }^{160}$ A KUZNYEC szovjet ejtöernyős partizán osztag erdei küzdelmét hiábavalónak tartó partizán NAGY Mihály volt, aki civil ruhát szerzett és újpesti otthonába távozott, ahol saját ellenálló csoportot szervezett. Az 1944. IX. 11-én elfogott magyar partizán NÉMETH Károly volt.

KIS: Magyarokra nem lövünk! Egy ejtőernyős partizáncsoport története. II. op.cit. 69-71.p.

${ }^{161}$ A pétervásári csendőr őrs tagjai által 1944. IX. 14-én elfogott négy magyar partizán CsIPAI Ferenc, VARGA János, PAPP Lajos és SZABÓ András voltak. A Németországba indított transzportból megszökött öt fö partizán CsIPAI Ferenc, VARGA János, PAPP Lajos, SZABÓ András és KeSZTENBAUM (KovÁCS) Imre voltak. MolotNAY Károly partizánt Sopronkőhidára szállították. NÉMETH Károly, DOBOS Zsigmond és GRESTYÁK István partizánok német táborba kerültek.

HIM-HL. PERS. op.cit. VII. 207. 232. d. 1944. 09. 15. ; LIPTAI: op.cit. 180-181.p.

${ }^{162}$ A Magyar Királyi Csendőrség 7. kerületének nyomozó alosztályát SzENTANDRÁSSY Elek cső.szds. vezette. Körözését rendelte el a KUZNYEC szovjet ejtőernyös partizán osztag hat tagjának, köztük NAGY Mihály és Kis András magyar partizánoknak.

HIM-HL. CSÖ. VII. Cső. Ker. Eln. B. 1734/1944. ; ÖLVEDI: Az 1. magyar hadsereg története, 1944. január 6-ától október 17-éig. op.cit. 138.p.

${ }^{163}$ Az osztag tagjai voltak: Mihail PERECSINSZKIJ föhadnagy parancsnok, Pavel HudinEC politikai helyettes, Ivan DREBUSCSAK föhadnagy törzsparancsnok, Tatjana KolOMIJEC és Nyikolaj SzEMJONOV rádiós, Ivan CsEREPENKo robbantó, Ivan Babinec, Mihail Kovtan, Jurij Sztanko, Andrej Szerbin, František Antalik, Ivan Szuvak, Nyikolaj Cerkovnyik, Ivan KRISKO, Mihail SCHNEIDER, Pjotr PIVKACS. 
${ }^{164}$ A PERECSINSZKIJ szovjet ejtöernyös partizán osztag földet érésekor eltünt három partizán Nyikolaj SzEMJONOv, Ivan CSEREPENKO és Ivan SZUVAK voltak.

ALEKSZEJENKO - BABIDORICS: op.cit. 214-215.p.

${ }^{165}$ A csoport tagjai: Vaszilij MAHARITA föhadnagy parancsnok, Mihail KricsFALuSI politikai helyettes, Anton PASZIJKO törzsparancsnok, Nyikolaj Jurov orvos, Anatolij SzLINYKo és Borisz BuRMISZTrov rádiós, Ivan SzERGYuk, Georgij ILJIN, valamint a kárpátaljai Vaszilij Szavko, Nyikolaj Kubarics, Vaszilij HumencsaK, Dmitrij Popovics, Vaszilij BunCSA, Dmitrij JaremCSuK, Vaszilij Risko, Mihail Ivanyina, Vaszilij TAFIJCSUK, Mihail Bondar, Vaszilij VaJdA.

${ }^{166}$ A MAHARITA szovjet ejtöernyös partizán osztag parancsnoka Vaszilij MAHARITA volt.

ALEKSZEJENKO - BABIDORICS: op.cit. 214-215.p.

${ }^{167}$ A MoROzov szovjet ejtőernyős partizán osztag parancsnoka Sz.G. MoROzov volt.

HIM-HL. PERS. op.cit. VII. 207. 232. d. 1944. 09. 28. ; Gazsi: A magyarországi ellenállási és partizánmozgalom a felszabadító hadmüveletek idején. op.cit. 339.p. ; Liptai: op.cit. 155.p.

${ }^{168} \mathrm{Az}$ 1944. IX. 18-án Bóly község körzetében a német-magyar és a szovjet partizánok közötti tüzharc során életét vesztette NAGY László cső.örm., PÁLYI Lajos cső.szkv. és SzOTYORI Sándor honv.szkv.

HIM-HL. PERS. op.cit. VII. 207. 232. d. 1944. 09. 21. ; Hősi halált halt. 625.p.

${ }^{169}$ A bodzaújlaki csendör örs parancsnoka ANTAL Károly csö.ftörm., a nagykövesdi csendőr őrs parancsnoka VADNAI Lajos cső.ftörm., az alsómihályi csendőr őrs parancsnoka TóTH József cső.ftörm., a ricsei csendőr őrs parancsnok pedig ÚRFI Pál cső.ftörm. volt.

HIM-HL. PERS. op.cit. VII. 207. 232. d. 1944. 09. 28.

${ }^{170}$ A rappi csendőr őrs parancsnoka PUHA József cső.ftörm., a vilkei csendőr őrs parancsnoka BÁNYAI Imre cső.ftörm. volt. Loc.cit.

171 CSIFFÁRY: op.cit. 108.p.

${ }^{172} \mathrm{Az}$ ipolyvidéki csendőr őrs parancsnoka NAGY Károly cső.ftörm. volt.

MNL-OL. K-28. ME 1944-II-26 452. ; HIM-HL. PERS. op.cit. VII. 207. 232. d. 1944. 09. 28.

${ }^{173}$ A hangonyi csendör őrs parancsnoka BÁNÓcZI János cső.ftörm. voltak.

FERENCZY: Csendőrök, honvédek harca szovjet ejtőernyős csoportokkal Magyarországon. op.cit. 111-121.p.

${ }^{174}$ A borsodnádasdi csendőr őrs parancsnoka LÉNÁRT János I. cső.ftörm. volt.

MNL-OL. K-150. op.cit. BM.Eln. 3584. cs. 1944-V-7. ; REKTOR: op.cit. 243-244.p.

${ }^{175}$ A KozLOV szovjet ejtőernyős partizán osztag parancsnoka Vaszilij M. KOZLOV örnagy volt, a magyar részleget pedig GRUBICS zoltán vezette.

TóTH: op.cit. 11.p. ； KIs: Magyarokra nem lövünk! Egy ejtőernyős partizáncsoport története. I.op.cit. 74.p.

${ }^{176}$ Az osztag tagjai voltak: Vaszilij M. Kozlov parancsnok, V. M. VAszin százados, politikai helyettes, V. N. PoPOV törzsparancsnok, Ivan Andrejevics MAKSZIMOv rádiós, V. P. TYinOBAJEV, M. Sz. PAMIJ, V. T. VASZKov, J. A. IsZAKOvics és Alekszej Dmitrijevics SeSzTOV.

${ }^{177}$ Az osztag tagjai voltak: GRUBICs Zoltán parancsnok, FÁBRY József politikai helyettes, DAJKó Ferenc, LöwEI Dániel zászlós, KopPÁNY Sándor zászlós, RÁTI János, CsizMADIA István, GYENES József, HoRvÁTH István, PATAKi Pál, valamint Jevgenyij Pavlovics Scsebetovszkij, Vlagyimir Nyesztorovics Mandrik, A. A. Zvezdicsev, U. Sz. Versikov, P. F. Gyegtyarov, I. I. Dorosenko, Sz. Sz. SzTYePAnyuK, A. I. Koval.

${ }^{178}$ Az osztag tagjai voltak: KovÁCs Sándor tartalékos hadnagy, politikai helyettes, GoLDSLEGEL Ármin, ToLKAN Pál, SzINTAY István, CINKON János, NAGY József, HACSAVEC István, KAKUK Pál, UjHÁZi András, KósAi Lajos.

${ }^{179}$ GAZSI — HARSÁNYI: op.cit. 413-415.p. ; TÓTH: op.cit. 11.p.

${ }^{180} \mathrm{Az}$ egyik akciócsoport döntően oroszokból és szlovákokból állt, melynek a parancsnoka Dmitrijevics SESZTOV, politikai helyettese pedig Pavlovics SCSEBETOVSZKI lett. A másik akciócsoport tagjai döntően magyarok voltak, a parancsnoki tisztet GRUBICS Zoltán, a politikai helyettes tisztséget pedig FÁBRY József töltötte be.

GAZSI - HARSÁNYI: op.cit. 413-421.p.

${ }^{181}$ Loc.cit. 413-420.p.

${ }^{182}$ KIS: Magyar partizánok a Szovjetunióból. op.cit. 152.p.

${ }^{183}$ GAZSI - HARSÁNYI: op.cit. 421.p.

${ }^{184}$ HIM-HL. PERS. op.cit. VII. 207. 232. d. 1944. 10. 18.; MNL OL K 150 BM Eln. 3584. cs. 1944-V-7.

${ }^{185}$ MNL-OL. K-150. op.cit. 3584. cs. 1944-V-7. ; HIM-HL. PERS. op.cit. VII. 207. 232. d. 1944. 10. 25.

186 A KozLOV szovjet ejtöernyös partizán osztag egyik ackiócsoportjának robbantóit V.M. VASZIN és RÁTI János vezette. Az 1944. X. 25-én lesben álló 20 fős különítmény parancsnoka CsERVENÁK volt. A Kisgencs falu térségében a motorkerékpásor német híradó rajt elfogó partizánok parancsnoka BELÉNYI és VLAGYISZLAV volt.

GAZSI - HARSÁNYI: op.cit. 422.p.

${ }^{187}$ A KozLOV szovjet ejtőernyős partizán osztag „Sztalin” nevet viselő akciócsoportjának parancsnoka Jevgenyij NovAK, poéitikai helyettese pedig Vladimir Nyesztorovics MANDRIK vollt.

LIPTAI: op.cit. 272.p. ; GAZSI: A magyarországi ellenállási és partizánmozgalom a felszabadító hadműveletek idején. op.cit. 341-342.p. ; GAZSI - HARSÁNYI: op.cit. 418-419.p.

${ }^{188}$ A KozLOV szovjet ejtöernyős partizán osztag magyar akciócsoportjának az 1944. XI. 25-én rajtaütést végző különítményének parancsnoka FÁBRY magyar partizán volt.

GAZSI - HARSÁNYI: op.cit. 422., 437.p.

${ }^{189} \mathrm{Az}$ akciócsoport elesett parancsnoka GRUBICs Zoltán volt. Helyébe ÁDLER Károly lépett. Az akciócsoport tagjai törzsparancsnoknak FÁBRYt, politikai helyettesnek pedig PATAKIt választották. A kettéválást követően a Henclófalván maradt akciócsoport résznek a vezetője ÁDLER Károly maradt, míg a másik rész vezetését FÁBRY és PATAKI közösen végezte.

MNL-OL. K-150. op.cit. 3584. cs. 1944-V-7.

${ }^{190}$ A rozsnyói csendőr őrs parancsnoka DANI Sándor cső.ftörm.volt. az 1944. XI. 30-ai összecsapásban résztvevő KozLOV szovjet ejtőernyős partizán osztag magyar akciócsoportjának első különítményét ÁDLER Károly vezette. Ugyanezen a napon a magyar akciócsoport második különítménye Szomolnok közelében egy német alakulattal került összetüzésbe, ezeket a partizánokat FÁBRY vezette. Az 1944. XII. 2-án erődítést építő müszaki alakulaton rajtaütő magyar akciócsoport különítményét szintén FÁBRY vezette.

GAZSI - HARSÁNYI: op.cit. 423-424.p. 
${ }^{191}$ Loc.it. 443-445.p.

192 1944. XII. 7-én a német erök a KozLoV szovjet ejtőernyős partizán osztag magyar akciócsoportjának az egyik különítményét támadták meg, ahol a parancsnoki posztot ÁDLER Károly töltötte be. A magyar akciócsoport 1944. XII. 20. után ismét egyesült, a kivégzett ÁDLER Károly parancsnoki teendőit FÁBRY vette át, akinek a törzsparancsoka PATAKI, politikai helyettese pedig Dusza László lett. A KozLOV szovjet ejtőernyős partizán osztag szlovák-orosz akciócsoportjában harcoló magyar különítmény parancsnoka GYENES József volt, ez a különítmény ejtett foglyul egy tűzérségi figyelőpontot 1944. XII. 21 -én.

Loc.it. 450.p. ; LIPTAI: 259-260.p. + 282.p.

${ }^{193}$ GAZSI: A magyarországi ellenállási és partizánmozgalom a felszabadító hadműveletek idején. op.cit. 341-342.p. ; GAZSI — HARSÁNYI: op.cit. 418-419.p. s+ 435-436.p. ; TóTH: op.cit. 10.p.

${ }^{194} \mathrm{Az}$ 1944. IX. 18-án Sztaniszlavba vezényelt és magyarországi bevetésre tervezett, magyarokból álló szovjet ejtőernyős partizán osztag parancsnoka LEBOVICS József volt.

Az osztag tagjai voltak: SzITA Ferenc politikai helyettes, Olga Ivanovna PergeJEva rádiós, ANTAL István, Fegler (FüLEKI) István, OlÁH István, PetKó Sándor, SzALAi Sándor, Tengely József, TRESó Kálmán.

${ }^{195}$ A LEBOVICS szovjet ejtőernyős partizán osztag Putnok térségében 1944. IX. 19-ei leszállásakor ANTAL István partizán mindkét lábát eltörte TRESó Kálmán pedig szintén mozgásképtelenné vált.

NAGY - NÉMETH: 5-6.p. ; TÓTH: op.cit. 9-11.p. ; REKTOR: op.cit. 243-244.p. ; KATÓCs: 5.p. ; CSIFFÁRY: op.cit. 146-147.p.

196 Tо́тн József cső.ftörm. az alsómihályi, ADONYI József cső.ftörm. az eszkárosi, TóTH János cső.ftörm. pedig a pálházai csendőr örs parancsoka volt. a kasai csendőr szárny szakaszát IDOMONNAI András cső.alhdgy. vezette. Az összecsapás elején kézigránát találattól elesett Tengely és SzAlai partizán, OlÁH és PergeJevát partizánokat épedig tüzharcban lőtték le. A magánosan elmenekülő partizán FEGLER volt.

HIM-HL. PERS. op.cit. VII. 207. 232. d. 1944. 09. 20. ； KIS: Magyarokra nem lövünk! Egy ejtőernyős partizáncsoport története. I. op.cit. 75.p.

${ }^{197}$ A jászói csendőr őrs parancsnoka VÁMOs Bálint cső.ftörm. volt.

HIM-HL. PERS. op.cit. VII. 207. 232. d. 1944. 09. 28. ; GAZSI - HARSÁNYI: op.cit. 399-400.p.

${ }^{198}$ MNL-OL. K-28. ME 1944-II-26 452. ; HIM-HL. PERS. VII. 207. 232. d. 1944. 09. 26.

${ }^{199}$ Az osgyáni csendőr őrs parancsnoka ERDEI József cső.törm. volt.

HIM-HL. PERS. op.cit. VII. 207. 232. d. 1944. 09. 27.

${ }^{200}$ Loc.cit. VII. 207. 232. d. 1944. 10. 08.

${ }^{201}$ A LOGVINYENKO szovjet ejtöernyös partizán osztag parancsnoka Vaszilij Petrovics LOGVINYENKO, a törzsparancsnok V.I. VOZINSZKIJ, a politikai helyettes pedig J.K. SCSADRIN volt.

LIPTAI: op.cit. 288.p. + 350.p. ; GAZSI - HARSÁNYI: op.cit. 475-477.p.

${ }^{202}$ HIM-HL. PERS. op.cit. VII. 207. 232. d. 1944. 10. 09., 1944. 10. 10., 1944. 10. 12., 1944. 10. 13.

${ }^{203}$ Az első különítmény parancsnoka FARKAS Béla, a törzsparancsnok Ivan Ivanovics SzEDOv, a politikai helyettes pedig ViGON Károly.

Az osztag tagjai voltak: FARKAS Béla parancsnok, VIGON Károly politikai helyettes, Ivan Ivanovics SzEdOv törzsparancsnok, Maria Klementovna Parkavenko rádiós, VArga Sándor, Horváth Imre, Holló István, VARga Dezső, Tóth Mihály, GÁl Imre, VARGa László, BARABÁs Ferenc, SÁndor András, VARGa Béla, Verbisz Mihály, BLAu Ferenc, Pozicsek János, LeINTOLIK József.

${ }^{204}$ A második különítmény parancsnoka Andrej GAJDOS, a politikai helyettes pedig Galij Tyimofejevics TARABIN volt. GAZSI - HARSÁNYI: op.cit. 475-477.p.

205 1944. XII. 19-én az első akciócsoport parancsnoki teendőit BoDNÁR László vette át, az akciócsoport két különítménye vezetésének a teendőit pedig a továbbiakban SzEBENi Mihály és HALÁsz Miklós látta el.

LIPTAI: op.cit. 288.p. + 350.p. ; GAZSI - HARSÁNYI: op.cit. 475-477.p.

${ }^{206}$ Az osztag tagjai voltak: ÖRLEY Zoltán parancsnok, RÉDNER Tibor politikai helyettes, HoRVÁTh Lajos, PATUs Zsigmond, FANCZI István, TOMPSÓ Béla, valamint VLADIMIR törzsparancsnok, Olga GolovinA rádiós.

${ }^{207}$ HIM-HL. PERS. op.cit. VII. 207. 232. d. 1944. 10. 10. ; LIPTAI: op.cit. 246.p. ; GAZSI: A magyarországi ellenállási és partizánmozgalom a felszabadító hadmüveletek idején. op.cit. 340.p.

${ }^{208}$ 1944. X. 14-én FANCZI István és PATUs Zsigmond indultak élelmiszer beszerzésre. A partizán osztag elfogott tagjai közül RÉDNER Tibort és Olga GOLOVINÁT a németek Németországba szállították. ÖRLEY Zoltán és HoRVÁTH Lajos Tany községnél szökött meg a gyalogmenetből.

Tо́тH: op.cit. 9.p. ; KIs: Magyarokra nem lövünk! Egy ejtőernyős partizáncsoport története. I. op.cit. 75.p. ; KoczÓ: 4-9.p.

${ }^{209}$ A KUNDRESOV szovjet ejtőernyös partizán osztag törzsparancsoka V.V. SZLMOLENYINOV, a rádiós Vera BATYIZER, a felderítő pedig PEREI Mihály volt.

LIPTAI: op.cit. 286.p.

${ }^{210} \mathrm{Az}$ erdőbényei csendőr őrs parancsnoka SOMODI István cső.ftörm.volt.

GAZSI: A magyarországi ellenállási és partizánmozgalom a felszabadító hadműveletek idején. op.cit. 340.p.

${ }^{211}$ A MIRONOV szovjet ejtőernyős partizán osztag tagjai voltak Nyikolaj MiRONOv őrnagy, CAPLA Ignác, MoRAVCSIK Pál és Ján GRAC. Az 1944. XII. 18-án Korpona községben kivégzett 13 magyar és szlovák ember között volt LENGYEL József orvos és a körzet erdésze laz egész családjával.

HIM-HL. PERS. op.cit. VII. 207. 232. d. 1944. 11. 02.

${ }^{212}$ A deméndi csendör őrs parancsnoka NAGY Sándor csö.ftörm. volt.

MNL-OL. K-150. op.cit. BM.Eln. 3584. cs. 1944-V-7. ; HIM-HL. PERS. op.cit. VII. 207. 232. d. 1944. 10. 18., 1944. 10. 31.

${ }^{213}$ NÓGRÁdi Sándor kíséröi voltak: PAP Béla, MolNÁR II. János, KerEKES Lajos, José SANDO és Tanja SZAMSZONYENKO rádiós.

TóтH: op.cit. 11.p. KIS: Magyarokra nem lövünk! Egy ejtőernyős partizáncsoport története. I. 74.p. ; GAZSI-HARSÁNYI: op.cit. 494-495.p.

${ }^{214}$ A NÓGRÁDI Sándor által kért, korábban már a bevetésre felkészített partizán osztagok voltak a GUBA, a FöLDES, a CSATÁRI és a BogYó osztagok. A Kozlov szovjet ejtőernyős partizán osztagból Kijevben maradt 10 fö parancsnoka KovÁcs Sándor volt. A NóGRÁDI Sándor és POGRABENKo közös elöljárója SZTOKACS altbgy. volt.

GAZSI - HARSÁNYI: op.cit. 507-508.p.

${ }^{215}$ Loc.cit. 515-516.p. 
${ }^{216}$ Az 1944. X. 18-án Tri Duby-ra szovjet repülőgéppel érkező összekötő RÁKOSI (KARDOS) Éva volt.

${ }^{216}$ LIPTAI: op.cit. 332.p. ; TóTH: op.cit. 11.p. ; KIS: Magyarokra nem lövünk! Egy ejtőernyős partizáncsoport története. I. 74.p.

${ }^{217}$ NÓGRÁDI Sándor számára a JEGOROV szovjet ejtőernyős partizán osztag által átadott két tiszt Jevgenyij LAPSOV százados és Szergej RAHMANOv föhadnagy volt.

GAZSI - HARSÁNYI: op.cit. 494-495.p. + 507-508.p. + 515-516.p.

${ }^{218}$ A NÓGRÁDI szovjet ejtöernyős partizán osztaghoz tartozott többek között: KURIMSZKY Sándor politikai helyettes, LAPSOV törzsparancsnok, RAHMANOV felderítő parancsnok, TÖMPE András, PAPP Béla, MolNÁR János, BÁrsONY Máté, KEREKES Lajos, SANDOVAL és SZAMSZONYENKO rádiós, KARDOs Éva rádiós. Az osztaghoz több magyar és szlovák katona csatlakozott: HöNING József, Pavel VeCSERA örmester, Andrej KuBAn szakaszvezető, LETKO Károly tizedes, Jan FrIDRICZ.

DÉKÁN - D. KARDOS: op.cit. 554-555.p.

${ }^{219}$ A NÓGRÁDI szovjet ejtöernyös partizán osztag parancsnoka mellett a Hrabcsa tanyán TöMPE András, MOLNÁR János, PAPP Béla és SZAMSZONYENKO maradtak.

GAZSI - HARSÁNYI: op.cit. 496-502.p. + 622-625.p. ; KARDOS: 203-204.p.

${ }^{220}$ A NÓGRÁDI szovjet ejtöernyös partizán osztag 1944. XII. 21-én átszervezett törzsébe tartozott: TöMPE András politikai helyettesként, LAPSOV törzsparancsnokként, RAHMANOV pedig felderítő parancsnokként.

LiPTAI: op.cit. 235.p. ; KARDOS: op.cit. 206-209.p. ; GAZSI - HARSÁNYI: op.cit. 496-502.p.

221 TÓTH: op.cit. 10-11.p. ; DÉKÁN — D. KARDOS: op.cit. 554-555.p.

${ }^{222}$ Az oprisoveci táborban1944 végén bevetésre váró öt magyar osztag vesztegelt, ezek voltak a CSATÁRI szovjet ejtőernyös partizán osztag, a FöLDES szovjet ejtőernyös partizán osztag, a GUBA szovjet ejtőernyös partizán osztag, a BoGYó szovjet ejtőernyös partizán osztag és a KOVÁCS szovjet ejtöernyös partizán osztag.

GYERZSALUK: Adalékok a magyar partizánok kiképzéséhez nyújtott szovjet segítség történetéhez. op.cit. 720.p. ; GAZSI HARSÁNYI: op.cit. 400.p. ; LIPTAI: op.cit. 243-252.p.

${ }^{223}$ GAZSI: A magyarországi ellenállási és partizánmozgalom a felszabadító hadmüveletek idején. op.cit. 341.p. ; GYERZSALUK: A Bujanov-Lencsés. op.cit. 547-549.p.

${ }^{224}$ Az 1944. X. 6-án fertőd közelében ledobott szovjet ejtőernyős partizán osztag parancsnoka REUTER Jenő volt. A móri csendőr őrs parancsnoka SzIGETI József csö.ftörm. volt.

LIPTAI: op.cit. 276.p. ; GAZSI: A magyarországi ellenállási és partizánmozgalom a felszabadító hadműveletek idején.op.cit. 341.p.

${ }^{225}$ HIM-HL. MAEM. op.cit. VII. 205. Jefimov 1944. 11. 27. ; ALEKSZEJENKO - BABIDORICS: op.cit. 133.p. + 147-148.p.

${ }^{226}$ KIs: Magyarokra nem lövünk! Egy ejtőernyős partizáncsoport története. I. op.cit. 75-76.p.

Megjegyzés a KÖVENDY névhez : A KÖVENDY név írói álnév. Az író — aki a Magyar Királyi Csendőrség tisztje volt — emigrációba kényszerülve az Amerikai Egyesült Államokban telepedett le. Itt írta visszaemlékezéseit. „A »kövendi« a család nemesi előneve volt, ezért vette át azt, mint írói álnevet KöVENDY-re módosítva”. (A Magyar Királyi Csendőr Bajtársi Közösségnek a szerkesztőségünk megkeresésére küldött válaszleveléből.) A szerző azért használt írói álnevet, mert nem kívánta a Magyarországon élő rokonságát kitenni a korabeli magyar pártállam állambiztonsági szervezetei vegzálásának. (a szerk.) 
Forrás- és irodalomjegyzék (a jegyzetekben alkalmazott röviditések oldása):

\section{MONOGRÁFIÁK, KISMONOGRÁFIÁK ÉS HASONLÓ JELLEGÜ KÖTETEK}

ALEKSZEJENKO - BABIDORICS (9.;43.;64.;68.;69.;73.;75.;79.;81.; 82.;85.;91.;93.;94.;98.,99.;106.;109.;

111.;112.;113.;114.;115.;117.;118.;

121.;123.;125.;128.;132.;164.;166.; 225.;)

CSIFFÁRY

(132.;136.;138.;155.;171.;195.;)

\section{DÉKÁN}

$(19 . ; 20 . ;)$

DÉKÁN - D. KARDOS

(13.;21.;140.;148.;218.;221.;)

FÖLDES

(144.;145.;146.;148.;)

HORVÁTH

(26.;31.;32.;35.;)

KAISER

(1.;6.;)

KÖVENDY: Csendörök a Kárpátokon. Egy csendörtiszt naplója Magyarország történelmének legnehezebb és legszomorúbb idejéböl.

(95.;130.;)

KÜHNRICH

(140.;)

LIPTAI

(8.;10.;11.;37.;41.;91.;107.;108.;129.;

133.;136.;137.;138.;149.;151.;161.;

167.;187.;192.;201.;205.;207.;209.;

216.;220.;222.;224.;)

MOLNÁR

(46.;49.;)

NAGY - NÉMETH

(195.;)

ÖLVEDI: Az 1. magyar hadsereg története, 1944. január 6-ától október 17éig.

(100.;162.;)

PARÁDI : A Magyar Királyi Csendőrség. Az elsö magyar polgári, központositott, közbiztonsági örtestület 1881-1945.

(3.;)

PUSKAS

(93.;)

REKTOR

$(1 . ; 2 . ; 3 . ; 8 . ; 14 . ; 86 . ; 87 . ; 95 . ; 130 . ; 174 . ;$ 194.;)
- AlekszejenKo, Grigorij Davidovics - BABIDORICs, Mihail Ivanovics: Fényjelek a hegyek között. Budapest - Ungvár, 1985, Kossuth Könyvkiadó - Kárpáti Kiadó. 256 p. HU-ISBN 9630926989.

- CSIFFÁRY Gergely: Életutak - életsorsok. Az antifasiszta fegyveres harc Heves megyei résztvevöinek életrajzi gyüjteménye. Eger, 1985, Heves Megyei Levéltár. 195 p. HU-ISBN 963015629 6. /Tanulmányok Heves Megye történetéből, 8./ HU-ISSN 0133-8153.

- DÉKÁN István: Hazatérés. Egy magyar partizánparancsnok visszaemlékezései 1942-1944. Budapest, 1960, Zrínyi Katonai Könyvkiadó. 191 p.

- DÉKÁN István - D. KARdos Éva: Utak és ösvények. Budapest, 1975, Magvető Kiadó. 491 p. HU-ISBN 9632700120.

- FöldES Pál: Két ugrás az ismeretlenbe. Budapest, 1975, Zrínyi Katonai Kiadó - Kossuth Kiadó. 268 p. HU-ISBN 9633266149.

— HorvÁth Miklós: Maléter Pál. Budapest, 1995, Osiris - Századvég Kiadó - 1956-os Intézet. 399 p. HU-ISBN 9633790360.

- KAISER Ferenc: A Magyar Királyi Csendörség története a két világháború között. Pécs, 2002, Pro Pannónia Kiadó Alapítvány. 175 p. HU-ISBN 963 907982 0. /Pannónia Könyvek./ HU-ISSN 0237-4277.

- KöVENDY Károly: Csendörök a Kárpátokon. Egy csendörtiszt naplója Magyarország történelmének legnehezebb és legszomorúbb idejéböl. Kézirat. s.l., 1953, s.n.

- KüHnRICH, Heinz: Partizánháború Európában 1939-1945. [Der Partisanenkrieg in Europa.] Ford.: Porga Lajos. Budapest, 1973, Zrínyi Katonai Kiadó. 335 p. HU-ISBN -

- LipTAi Ervin (szerk.): A magyar antifasiszta ellenállás és partizánmozgalom. Budapest, 1987, Hadtörténeti Intézet és Múzeum - Kossuth Könyvkiadó. 373 p. HU-ISBN 9630931060.

— MolNÁR István: Fegyver ropog a Buzsorán. Budapest, 1956, Szikra. 155 p.

- NAGy Károly - NÉMETH Gyula: Fegyverrel a hazáért, a fasizmus ellen. (I. országos ejtőernyős szervező partizántalálkozó, Ózd - Hangony, 1986. augusztus 8-9.) Ózd, 1986, Lajos Árpád Honismereti Kör. 8 p. HU-ISBN -

- ÖLVEDI Ignác: Az 1. magyar hadsereg története, 1944. január 6-ától október 17-éig. Budapest, 1989, Zrínyi Katonai Kiadó. 318 p. HU-ISBN 963 3270154 .

- PARÁDI József: A Magyar Királyi Csendőrség. Az első magyar polgári, központositott, közbiztonsági örtestület 1881-1945. Budapest, 2012, SZBMRTT. 281 p. HU-ISBN: 978963084794 0. /A magyar rendvédelemtörténet öröksége 2./ HU-ISSN: 2062-8447.

- Puskas, Andrej Ivanovics: Vengrija v gody vtoroj mirovoj vojny. [Magyarország a második világháborúban.] Moszkva, 1966, Nauka. 524 p.

- ReKTor Béla: A Magyar Királyi Csendörség oknyomozó története. Cleveland, 1980, Árpád Könyvkiadó. 552 p. USA-ISBN 0934214018. 
SZEMIRJAGA

(4.;140.;)
UJVÁRI

(46.;56.;61.;63.;77.;78.;81.;85.;90.;)

UszTA: A jót akarni kell.

(46.;49.;51.;56.;70.;75.;90.;)

VADÁSZ

$(21 . ; 46 . ;)$
GRECSKO Andrej Antonovics (szerk.): A második világháború története 1939-1945. [История второй мировой войны, 1939-1945.] Budapest, 1976-1984, Zrínyi.

- I.köt. GYEBORIN Georgij (szerk.): A háború keletkezése. A haladó erök harca a béke fenntartásáért. [Зарождение войны. Борьба прогрессивных сил за сохранение мира.] Ford.: DALOS György - NÁDOR Tibor. A magyar nyelvű kiadást szerkesztette: BEDŐ László. Budapest, 1976, Zrínyi. 520 p. HU-ISBN 9633262321.

- II.köt. Gyeborin Georgij (szerk.): A háború elöestéje. [Накануне войны.] Ford.: HoRVÁtн Zoltán — SöRös Lajos. A magyar nyelvü kiadást szerkesztette: Ács Tibor — BEDÖ László — Kocsis Bernát. Budapest, 1976, Zrínyi.600 p. HU-ISBN 963326233 X.

- III.köt. Gyerevjanko Petr Mihaliovics (szerk.): A háború kezdete. A Szovjetunió elleni agresszió elökészitése. [Начало войны. Подготовка агрессии против CCCP.] Ford.: HARSÁNYI János - NÁDOR Tibor. A magyar nyelvű kiadást szerkesztette: Ács Tibor — BEDŐ László - Kocsis Bernát. Budapest, 1977, Zrínyi. 655 p. HU-ISBN 9633262410.

- IV.köt. ANDRONYIKOv Nyikolaj Grigorjevics (szerk.): Fasiszta agreszszió a Szovjetunió ellen: A villámháború hadászatának csödje. [Фашистская агрессия против СССР. Крах стратегии „молниеносной войны”.] Ford.: HORVÁTH Zoltán — NÁDOR Tibor. A magyar nyelvü kiadást szerkesztette: BEDö László. Budapest, 1977, Zrínyi. 718 p. HU-ISBN 96332 62429 .

- V.köt. Morozov Vaszilij Vaszilijevics (szerk.): A fasiszta tömb agreszsziv terveinek kudarca. [Провал агрессивных планов фашистского блока.] Ford.: TÖLGYES Ernő. A magyar nyelvü kiadást szerkesztette: BEDÖ László. Budapest, 1978, Zrínyi. 750 p. HU-ISBN 9633262534.

- VI.köt. PAROTKIN Iván Vasziljevics (szerk.): Gyökeres fordulat a háborúban.. [Коренной перелом в войне.] Ford.: NÁDOR Tibor. Budapest, 1978, Zrínyi. 757 p. HU-ISBN 9633262593.

- VII.köt. SzolovJev Borisz Grigorjevics (szerk.): A háborúban bekövetkezö gyökeres fordulat betetözödése. [Завершение коренного перелома в войне.] Ford.: TÖLGYES Ernő. A magyar nyelvü kiadást szerkesztette: BEDÖ László. Budapest, 1979, Zrínyi. 756 p. HU-ISBN 9633262690.

- VIII.köt. JeVgenYiJ Petrovics Jegorov (szerk.): A fasiszta tömb hadászati védelmének összeomlása. [Крушение оборонительной стратегии фа-шистского блока.] Ford.: HoRvÁTH Zoltán — SoROs Lajos. A magyar nyelvű kiadást szerkesztették: Ács Tibor - BEDŐ László - Kocsis Bernát. Budapest, 1980, Zrínyi. 692 p. HU-ISBN 9633262763.

- IX.köt. SzEMIRJAGA Mihail Ivanovics (szerk.): A Szovjetunió és az európai államok területének felszabaditása. A csendes-óceáni és ázsiai háború. [Освобождение территории ссср и европейских стран. Война на тихом океане и в азии.] Ford.: TÖLGYESI Ernő. A magyar nyelvü kiadást szerkesztették: Ács Tibor — BEDŐ László - SzABÓ Egon. Budapest, 1980, Zrínyi katonai Kiadó. 745 p. HU-ISBN: 963326259 X.

- X.köt. SeHovcov Nyikolaj Ivanovics (szerk.): A fasiszta Németország szétzúzásának befejezése. [Освобождение территории ссср и европейских стран. Война на тихом океане и в азии.] Budapest, 1981, Zrínyi katonai Kiadó. 726 p. HU-ISBN: 9633260868.

- XI.köt. VAsziLuj Acskaszov (szerk.): A militarista Japán szétzúzása. A második világháború befejezése. [Поражение милитаристской Японии. Окончание второй мировой войны.] A magyar nyelvü kiadást szerkesztette: SZABÓ Egon. Budapest, 1982, Zrínyi katonai Kiadó. 637 p. HU-ISBN: 9633261031 .

- XII.köt. NYIKOLAJ Andronyikov — TuCSKEVICS Sztelan (szerk.): A második világháború mérlege és tanulságai. [Итоги и уроки второй мировой войны.] A magyar nyelvű kiadást szerkesztette: SzABÓ Egon. Budapest, 1984, Zrínyi katonai Kiadó. 634 p. HU-ISBN: 9633263247.

UjVÁRI Imre László: Jelzőtüzek a Buzsorán. Az Uszta-Priscsepa partizánosztag története. Budapest, 1985, Zrínyi Katonai Kiadó. 53 p. HU-ISBN 963850012 4. /A szabad Magyarországért./ HU-ISSN 8500-0299.

- UszTA Gyula: A jót akarni kell. Budapest, 1989, Zrínyi Katonai Kiadó. 388 p. HU-ISBN 963326595 9. /Élmények és gondolatok./ HU-ISSN 0236-5588.

- VADÁSz Ferenc: Legenda nélkül. Száz partizán és ellenálló története. Budapest, 1975, Móra Kiadó. 247 p. HU-ISBN 9631102459. 


\section{TANULMÁNYOK}

FERENCZY: Egyéb partizántevékenységek.

(8.;147.;)

FORRÓ

(5.;)

GAZSI: Antifasiszta ellenállás és partizánharc Magyarországon.

(30.;)

GAzSI: A magyarországi ellenállási és partizánmozgalom a felszabadító hadmüveletek idején.

(7.;11.;23.;28.;38.;136.;138.;159.;

167.;193.;207.;210.;223.;224.;)

GIBÁS

(49.;145.;)

GYERZSALUK: Adalékok a magyar partizánok kiképzéséhez nyújtott szovjet segítség történetéhez.

(7.;11.;73.;139.;222.;)

GYERZSALUK: A Bujanov-Lencsés partizáncsoport tevékenysége.

(133.134.;135.;137.;223.;)

HEGEDÜS

(5.;)

HEGEDÜS - TURCSÁNYI

(37.;65.;)

HíDVÉGI

(17.;)

KIS: Magyar partizánok a Szovjetunióból.

(12.;38.;145.;182.;)

KIS: Magyarokra nem lövünk! Egy ejtőernyős partizáncsoport története. I. (13.;19.;28.;33.;134.;142.;153.;155.; 175.;196.;208.;213.;216.,226.;)

KIS: Magyarokra nem lövünk! Egy ejtőernyős partizáncsoport története. II. rész.

(156.;157.;159.;160.;196.;)

KosZTYÓ: Irreguláris szovjet katonai egységek Kárpátalján. A Rákóczi-partizánosztag működése Kárpátalján a magyar rendvédelmi szervek iratainak tükrében.

(54.;55.;63.;67.;76.;79.;)
FERENCZY Márton: Egyéb partizántevékenységek. 117-122.p. In: SZALAY Gyula (szerk.): A világjáró csendőr. A Magyar Királyi Csendör Bajtársi Közösség okmányai alapján. Pécs, 2002, Gálos Nyomdász Kft. 223 p. HUISBN 9638615338 .

— FORRÓ János: A rendvédelmei szervezetek sajátos tevékenysége háborús helyzetben Fejér megyében 1944 őszétől 1945 tavaszáig. Rendvédelem-történeti Füzetek (Acta Historiae Praesidii Ordinis), XXII.évf. (2012) 26.sz. 35-43.p. HU-ISSN 1216-6774.

- GAzSI József: Antifasiszta ellenállás és partizánharc Magyarországon. 55116.p. In DOMBRÁDY Lóránd — NAGY Gábor (szerk.): Fegyverrel a hazáért. Budapest, 1980, Kossuth Könyvkiadó - Zrínyi Katonai Kiadó. 295 p. ISBN 9630915049.

GAZSI József: A magyarországi ellenállási és partizánmozgalom a felszabadító hadmüveletek idején. 331-366.p. In: SzÁva Péter (szerk.): $M a-$ gyarország felszabaditása. Tanulmányok hazánk felszabaditásának történetéből. Budapest, 1975, Zrínyi Katonai Kiadó - Kossuth Kiadó. 417 p. HU-ISBN: 9633262119.

— GIBÁs Andor: Szemelvények a magyar ejtőernyőzés történetéből (1945ig). 7-15.p. In ZÖRGÖ Tibor (szerk.): A Repüléstörténeti Társaság 2001. évi évkönyve. Budapest, 2001, Magyar Repüléstörténeti Társaság. 269 p. HUISSN 1416-5287.

- GyerzSAluK, Nyikolaj: Adalékok a magyar partizánok kiképzéséhez nyújtott szovjet segítség történetéhez. Hadtörténelmi Közlemények, XXIII.évf. (1976) 4.sz. 710-722.p. HU-ISSN 0017-6540.

GyERZSALUK Nyikolaj: A Bujanov-Lencsés partizáncsoport tevékenysége. Hadtörténelmi Közlemények, XXXI.évf. (1984) 3.sz. HU-ISSN 00176540. 540-549.p.

— Hegedüs Ernő: A Magyar Királyi Csendőrség harc- és gépjármüvei. 99114.p. In: PARÁDI József et al. (szerk.): Magyar csendörség-történeti tanulmányok. Budapest, 2015, Magyar Királyi Csendőr Bajtársi Közösség - Szemere Bertalan Magyar Rendvédelem-történeti Tudományos Társaság. 402 p. HUISBN 978963898288 9. /Magyar rendvédelem-történeti tanulmányok, 1./ HU-ISSN 2415-9875.

— HegEdüS Ernő - TuRCSÁNYI Károly: Légideszant alakulatok rendvédelmi szerepkörben. Rendvédelem-történeti Füzetek (Acta Historiae Praesidi Ordinis) XIV.évf. (2008) 17.sz. 97-104.p. HU-ISSN 1216-6774.

— HíDVÉGI Fábián: A Bánffyhunyadi csendőrszázad harcai. 108-110.p. In: Szalay Gyula (szerk.): A világjáró csendőr. A Magyar Királyi Csendőr Bajtársi Közösség okmányai alapján. Pécs, 2002, Gálos Nyomdász Kft. 222 p. HUISBN 9638615338.

KIS András: Magyar partizánok a Szovjetunióból. 140-161.p. In M. KISS Sándor (szerk.): Magyarország 1944. Fejezetek az ellenállás történetéböl. Budapest, 1994, Nemzeti Tankönyvkiadó. 330 p. HU-ISBN 9631854892.

KIS András: Magyarokra nem lövünk! Egy ejtőernyős partizáncsoport története. I. rész. Hitel, IX.évf. (1996) 1.sz. 72-80.p. HU-ISSN 0238-9908.

KIs András: Magyarokra nem lövünk! Egy ejtőernyős partizáncsoport története. II. rész. Hitel, IX.évf. (1996) 2.sz. 61-72.p. HU-ISSN 0238-9908.

KosZTYó Gyula: Irreguláris szovjet katonai egységek Kárpátalján. A Rákóczi-partizánosztag működése Kárpátalján a magyar rendvédelmi szervek iratainak tükrében. 365-379.p. In EKERT Mária - MoLNÁR Attila Károly (szerk.): Teremtés - politika és müvészet. Budapest, 2015, NKE Molnár András Kutató Központ. 466 p. HU-ISBN 9786165527739. 
KosZTYÓ: Az Uszta-Priscsepa partizánosztagok tevékenysége Kárpátalján (1944. augusztus 8. - október 26.). (49.;54.;58.;63.;70.;82.;86.;89.;)

KÖVENDY: A délvidéki partizánharcok (6.;)

OFICINSZKIJ

$(100 . ; 139 . ;)$

ÖLVEDI: Emlékek és adalékok néphadseregünk születéséhez.

(95.;)

PARÁDI: A csendőrség magyarországi története.

(5.;)

PERJÉSI

(2.;)

SZAGYILENKO

(151.;152.,)

То́тн

(13.;27.;34.;37.;41.;91.;132.;153.;

156.;158.;175.;179.;193.;195.;208.;

213.;216.;221.;)

UsZTA: Rákóczi neve alatt..

(71.;84.;)

\section{CIKKEK}

BERTALAN

(24.;)

FERENCZY: Csendőrök, honvédek harca szovjet ejtőernyős csoportokkal Magyarországon.

(6.;88.;146.;147.;157.;173.;)

Hősi halált halt.

(168.;)

Hősi halált haltak.

(119.;)

KATÓCS

(195.;)

KoczÓ

(208.;)

TIMÁR

(24.;)

TÖRÖK

(14.;)
KosZTYÓ Gyula: Az Uszta-Priscsepa partizánosztagok tevékenysége Kárpátalján (1944. augusztus 8. - október 26.). 127-152.p. In DuPKA György ZUBÁNICs László (szerk.): A Kárpát-medencéböl elhurcolt magyar és német rabok nyomában Oroszföldön és a Kaukázus országaiban. Ungvár - Budapest, 2017, Intermix Kiadó. 244 p. HU-ISBN: 978963981488 2. /Kárpátaljai Magyar Könyvek, 256./ HU-ISSN 1022-0283.

KöVENDY Károly: A délvidéki partizánharcok. 166-171.p. In: KöVENDY Károly: A Magyar Királyi Csendörség a törvény és a rend szolgálatában 1881-1945. A csendör békében, háborúban és emigrációban. (Összeállítás az MKCsBK lapjában, a Bajtársi Levélben megjelent cikkekből). Toronto, 1973, Sovergin. 430 p.

- OFicinszKiJ Romám: Kárpátalja kérdése a második világháború végén, 1944-1945. 209-215.p. In FedineC Csilla - VeHEs Mikola (szerk.): Kárpátalja 1919-2009, történelem, politika, kultúra. Budapest, 2010, Argumentum - MTA Etnikai-nemzeti Kisebbségkutató Intézete. 640 p. HU-ISBN 9789634465966 .

— ÖLVEDI Ignác: Emlékek és adalékok néphadseregünk születéséhez. Hadtörténelmi Közlemények, XXVII.évf. (1980) 3.sz. 464-490.p. HU-ISSN 0017-6540.

PARÁDI József: A csendőrség magyarországi története. 161-200.p. In: PARÁDI József et al. (szerk.): Magyar csendörség-történeti tanulmányok. Budapest, 2015, Magyar Királyi Csendőr Bajtársi Közösség - Szemere Bertalan Magyar Rendvédelem-történeti Tudományos Társaság. 402 p. HU-ISBN 978963 898288 9. /Magyar rendvédelem-történeti tanulmányok, 1./ HU-ISSN 2415-9875.

— PERJÉSI György (ifj.): A Magyar Királyi Csendőrség létszámalakulása 1938-1945. Rendvédelem-történeti Füzetek (Acta Historiae Praesidii Ordinis), XIII.évf. (2007) 16.sz. 106-107.p. HU-ISSN 1216-6774.

- SzagYiLenko, Alekszej Mihajlovics: A mi magyar barátaink. [Наши венгерские друзья.] Ford.: DomA Lászlóné. Hadtörténelmi Közlemények, XII.évf. (1965) 3.sz. 650-655.p. HU-ISSN 0017-6540.

- Tо́тн Ferenc: Magyar ejtőernyős partizánok. A Repüléstörténeti Konferencia Közleményei, XXVII.évf. (2002) 27.sz. 9-12.p. HU-ISSN 14165287.

- UszTa Gyula: Rákóczi neve alatt... 138-152.p. In Petrák Katalin VÁGÓ Ernő (szerk.): Harcok, emlékek. Magyar partizánok Európa küzdőterein. Budapest, 1969, Zrínyi katonai Kiadó. 428 p. HU-ISBN -

- Bertalan Ágnes: A veterán: partizánok segítője. Szabad Föld, XXVI.évf. (1980.) 18.sz. 4.p. HU-ISSN 0133-0950.

FERENCZY Márton: Csendőrök, honvédek harca szovjet ejtőernyős csoportokkal Magyarországon. 111-121.p. In: KöVENDY Károly et al. (szerk.): A Magyar Királyi Csendörség a törvény és a rend szolgálatában 1881-1945. A csendör békében, háborúban és emigrációban. (Összeállítás az MKCsBK lapjában, a Bajtársi Levélben megjelent cikkekből). Toronto, 1973, Sovergin. $430 \mathrm{p}$.

- Hősi halált halt. (Szerkesztőségi közlemény.) Csendörségi Lapok, XXXIV.évf. (1944) 20.sz. 625.p.

- Hősi halált haltak. (Szerkesztőségi közlemény.) Csendőrségi Lapok, XXXIV.évf. (1944) 21.sz. 657.p.

— KaTócs Gyula: ...és mégis élek. Új Szó, XVII.évf. (1989) 203.sz. 5.p. HU-ISSN 1335-7050.

— Koczó József: Partizánvadászat áldozata lett a 16 éves diák. Börzsöny Helikon, XI.évf. (2016) 3.sz. 4-9.p. HU-ISSN -

- TimÁr Imre: A partizán. Békés Megyei Népújság, XXXIX.évf. (1984) 235.sz. 7.p. HU-ISSN 0133-0055.

- TöRÖK Benjamin: A nagyváradi tanzászlóalj a hadak útján. 127-130.p. In KöVENDY Károly: A Magyar Királyi Csendörség a törvény és a rend szolgálatában 1881-1945. A csendör békében, háborúban és emigrációban. (Összeállítás az MKCsBK lapjában, a Bajtársi Levélben megjelent cikkekből). Toronto, 1973, Sovereign. $430 \mathrm{p}$. 
HOLLÁDI

(15.;16.;17.;)

KARDOS

(219.;220.;)

KöVENDY: Csendőrök és partizánok harca a Kárpátokban. (86.;88.;95.;96.;106.;)

KöVENDY: Egy arany vitézségi érem és egy lovagkereszt története.

(130.;)

KöVENDY: A Martinkai ütközet. (83.;87.;)

\section{DOKUMENTUMKIADVÁNYOK}

GAZSI - HARSÁNYI

(22.;23.;30.;34.;39.;40.;42.;50.;51.; 52.,53.;55.;59.;60.;61.;64.;65.;66.;70.; 71.;76.;80.;84.;85.;89.;90.;96.;140.; 142.;179.;180.;181.;183.;186.;187.; 188.;190.;191.;192.;193.;197.;201.; 204.;205.;213.,214.;215.;217.;219.; 220.;222.;)

\section{LEVÉL-, IRAT-, ÉS DOKUMENTUMTÁRI GYÜJTEMÉNYEK}

HIM-HL. CSÖ.

(162)

HIM-HL. 1.HDS.

(75.;)

HIM-HL. KSZV.

(71.;)

HIM-HL. MAEM

(13.;28.;30.;33.;35.;153.;155.;225.;)

HIM-HL. TGY.

(89.;)

HIM-HL. PERS.

(29.;56.;57.;58.;61.;62.;65.;66.;72.; 74.;76.;77.;78.;83.;96.;103.;108.; 110.;119.;120.;122.;126.;127.;145.; 146.;148.;157.;158.;161.;167.;168.; 169.;170.;172.;184.;185.;196.;197.; 198.;199.;200.;202.;207.;211.;212.;)

MNL-OL. K-28.

(172.;198.,)

MNL-OL. K-149.

(45.;)

MNL-OL. K-150.

(72.;74.;77.;78.;102.;113.;116.;122.; 123.;124.;127.;174.,185.;189.;212.;) örségi Iratok) ponti Szállításvezetőség) mánygyüjtemények) náliák) vált iratok) nos iratok)
HoLlÁDI Ernő: Székelyföld védelme. 179-189.p. In KöVENDY Károly: A Magyar Királyi Csendörség a törvény és a rend szolgálatában 1881-1945. A csendör békében, háborúban és emigrációban. (Összeállítás az MKCsBK lapjában, a Bajtársi Levélben megjelent cikkekből). Toronto, 1973, Sovereign. 430 p. CA-ISBN -

- Kardos Éva: Hazatérés. 228-236.p. In PetráK Katalin - VÁGÓ Ernő (szerk.): Harcok, emlékek. Magyar partizánok Európa küzdöterein. Budapest, 1969, Zrínyi katonai Kiadó. 428 p. HU-ISBN -

- KöVENDY Károly: Csendőrök és partizánok harca a Kárpátokban. 143145.p. In KöVENDY Károly et al. (szerk.): A Magyar Királyi Csendörség a törvény és a rend szolgálatában 1881-1945. A csendör békében, háborúban és emigrációban. (Összeállítás az MKCsBK lapjában, a Bajtársi Levélben megjelent cikkekböl). Toronto, 1973, Sovereign. 430 p. CA-ISBN -

KöVENDY Károly: Egy arany vitézségi érem és egy lovagkereszt története. 149-156.p. In KöVENDY Károly et al. (szerk.): A Magyar Királyi Csendőrség a törvény és a rend szolgálatában 1881-1945. A csendör békében, háborúban és emigrációban. (Összeállitás az MKCsBK lapjában, a Bajtársi Levélben megjelent cikkekből). Toronto, 1973, Sovereign. 430 p. CA-ISBN -

- KöVEndy Károly: A Martinkai ütközet. 158-161.p. In: KöVENDy Károly: et al. (szerk.): A Magyar Királyi Csendörség a törvény és a rend szolgálatában 1881-1945. A csendör békében, háborúban és emigrációban. (Öszszeállítás az MKCsBK lapjában, a Bajtársi Levélben megjelent cikkekből). Toronto, 1973, Sovereign. 430 p. CA-ISBN -

— GAZSi József — HARSÁNYi László (szerk.): Magyar szabadságharcosok a fasizmus ellen. Dokumentumok a magyar antifasiszta ellenállási mozgalom történetéböl 1941-1945. Budapest, 1969², Hadtörténelmi Intézet és Múzeum - Zrínyi Katonai Kiadó. 906 p. HU-ISBN -

- HIM (Hadtörténeti Múzeum) HL (Hadtörténelmi levéltár) CSŐ. (Csend-

- HIM (Hadtörténeti Múzeum) HL (Hadtörténelmi levéltár) 1.HDS. (Magyar Királyi 1. Honvéd Hadsereg-parancsnokság)

HIM (Hadtörténeti Múzeum) HL (Hadtörténelmi levéltár) KSZV (Köz-

- HIM (Hadtörténeti Múzeum) HL (Hadtörténelmi levéltár) MAEM (Magyar Antifasiszta Ellenállási Mozgalom)

HIM (Hadtörténeti Múzeum) HL (Hadtörténelmi levéltár) TGY (Tanul-

— $\quad$ HIM (Hadtörténeti Múzeum) HL (Hadtörténelmi levéltár) PERS (Perso-

- MNL (Magyar Nemzeti Levéltár) OL (Országos Levéltár) K-28 (Nemzetiségi és kisebbségi osztály iratai)

- MNL (Magyar Nemzeti Levéltár) OL (Országos Levéltár) K-149 (Reser-

— MNL (Magyar Nemzeti Levéltár) OL (Országos Levéltár) K-150 (Általá- 